\title{
The Patricia Zn-Pb-Ag epithermal ore deposit: an uncommon type of mineralization in northeastern Chile
}

\author{
Darío Chinchilla ${ }^{\text {a, }}{ }^{*}$, Lorena Ortega a ${ }^{\text {a }}$ Rubén Piña ${ }^{a}$, Raúl Merinero ${ }^{\text {a }}$, Daniel Moncada ${ }^{\mathrm{c}}$, Robert J. \\ Bodnar $^{\mathrm{d}}$, Cecilio Quesada ${ }^{\mathrm{a}}$, Antonio Valverde ${ }^{\mathrm{e}}$, Rosario Lunar ${ }^{\mathrm{a}, \mathrm{b} .}$ \\ ${ }^{a}$ Departamento de Cristalografía y Mineralogía. Facultad de Ciencias Geológicas. Universidad \\ Complutense de Madrid. C/ José Antonio Novais, s/n. 28040, Madrid (Spain). \\ ${ }^{\mathrm{b}}$ Instituto de Geociencias IGEO (UCM-CISC), C/ José Antonio Novais, s/n. 28040, Madrid (Spain). \\ ${ }^{\mathrm{c}}$ Departamento de Geología and Andean Geothermal Center of Excellence (CEGA), Universidad de \\ Chile, Plaza Ercilla 803, Santiago, Chile. \\ ${ }^{\mathrm{d}}$ Department of Geosciences, Virginia Tech, Blacksburg, VA 24061, United States. \\ ${ }^{\text {e }}$ Herencia Resources Plc. Compañía minera Paguanta, Santiago de Chile, Chile.
}

\begin{abstract}
The Patricia ore deposit represents an unusual example of economic $\mathrm{Zn}-\mathrm{Pb}-\mathrm{Ag}$ mineralization at the northernmost end of the Late Eocene-Oligocene metallogenic belt in Chile. It is hosted by volcanosedimentary units, which are typically tuffaceous and andesitic breccias. The ore body consists of a set of subvertical E-W vein systems developed under a sinistral strike-slip regime that included transtensive domains with generalized extensional structures where the ores were deposited. The deposit is divided into two blocks by a set of NNW-ESE-trending reverse faults, which uplifted the eastern block and exhumed thicker and deeper parts of the deposit. At least $200 \mathrm{~m}$ of volcano-sedimentary pile hosting the mineralization has been eroded in this block. By contrast, the western block exposes a shallower part of the system where cherts, amorphous silica and jasperoids occur. Three main stages of mineralization have been defined: (1) pre-ore stage is characterized by early quartz, pyrite and arsenopyrite, (2) base-metal and silver stage; characterized by sphalerite (6 to 15 mol.\% FeS), galena, chalcopyrite, pyrrhotite and Agbearing minerals (freibergite, polybasite, stephanite, pyrargyrite, freieslebenite and acanthite) and (3) post-ore stage; characterized by late quartz, kutnohorite and minor sulfides (arsenopyrite, sphalerite,
\end{abstract}


pyrite, galena, Ag-bearing minerals and $\mathrm{Pb}$-sulfosalts). Whole-ore geochemistry shows two groups of elements that are positively correlated; 1) $\mathrm{Ag}-\mathrm{Cd}-\mathrm{Cu}-\mathrm{Pb}-\mathrm{Zn}$ related to the base metal sulfides and 2) $\mathrm{Au}-$ As-Ge-Sb-W related to arsenopyrite and pyrite. Hydrothermal alteration is pervasive in the outcropping mineralized areas, including silicification and locally, vuggy silica textures. At depth, chloritic and sericitic alteration is developed along vein selvages and is superimposed to the regional propylitic alteration. Fluid inclusions indicate that the base-metal ores were deposited from $250-150^{\circ} \mathrm{C}$ moderate salinity fluids (1-9 wt \% NaCl). The pre-ore stage is characterized by a saline fluid (6-22 wt $\% \mathrm{NaCl})$ and between 210 and $250^{\circ} \mathrm{C}$ whereas the post-ore stage has salinity of 4-8 wt \% and temperature from 175 to $215^{\circ} \mathrm{C}$. Cooling was the mechanism of ore mineral precipitation in the Patricia deposit, although mixing of fluids could have occurred in the pre-ore stage. Mineralogical, geochemical and fluid inclusion evidence is consistent with an intermediate sulfidation (IS) epithermal deposit type. This study highlights the high potential for hidden economic mineralization at depth in the western block and for extension of the ore body both to the south and to deeper levels in the eastern block of the Patricia ore deposit. To a larger extent, the implications of finding such polymetallic epithermal style of mineralization in the northern Chile Precordillera is relevant both to the regional metallogenic perspective and to the exploration potential of the region, where the late Eocene-early Oligocene metallogenic belt apparently disappears.

Keywords: intermediate-sulfidation, Ag-sulfosalts, open-space filling, polymetallic epithermal, strikeslip duplex, Domeyko fault system, metallogenic belt

\section{Introduction}

Several long and linear, orogen-parallel metallogenic belts have been defined along the Chilean Andes, each one developed during a distinct metallogenic epoch, ranging from Cretaceous to Early Eocene times (Fig. 1a) (Camus and Dilles, 2001). The metallogenic belts young continentwards away from the subduction zone located at the Pacific western margin of South America, following a migration similar to the active magmatic arc systems with time (Coira et al., 1982). The Late Eocene to Oligocene 
belt is the most important because it hosts the largest concentration of $\mathrm{Cu}$ resources in the world, mostly in the form of world-class porphyry copper deposits such as Chuquicamata, La Escondida and El Salvador (Behn et al., 2001; Sillitoe and Perelló, 2005; Maksaev et al., 2007). These porphyry Cu deposits are genetically related to epizonal plutons emplaced along the N-S oriented Domeyko fault system (Maksaev, 1990; Behn et al., 2001), whose episodic transpressional/transtensional kinematics eventually developed extensional areas favorable to the emplacement of shallow plutons. Queen Elizabeth deposit is the northernmost porphyry copper occurrence in the late Eocene - Oligocene belt within Chile (Sillitoe \& Perelló, 2005). The apparent termination of the belt in this region is a result of concealment beneath Miocene volcanic rocks (Sillitoe, 2010), and it further reappears in southern Peru (Los Chancas, Cotabambas, Antapaccay, and Ataspaca porphyry-type deposits, among others; Sillitoe and Perelló, 2005).

The Patricia $\mathrm{Zn}-\mathrm{Pb}-\mathrm{Ag}$ ore deposit displays a vein-like geometry and intermediate sulfidation epithermal characteristics and it is located close to the northernmost end of the Late Eocene to Oligocene porphyry $\mathrm{Cu}$ belt in Chile, some kilometers apart from the Queen Elizabeth porphyry copper deposit (Fig. 1b). Geographically, it occurs in the Tarapacá Province, I Región, Chile, at latitude $19^{\circ} 81^{\prime} \mathrm{S}$ and longitude $69^{\circ} 06^{\prime} \mathrm{W}, 150 \mathrm{~km}$ northeast of Iquique and $30 \mathrm{~km}$ west of the international border with Bolivia (Figs. 1a and $1 \mathrm{~b}$ ). Other porphyry copper mines and prospects in the nearby region occur either related to the Paleocene-early Eocene belt (Cerro Colorado, Bouzari and Clark, 2002; Cotton, 2003; and Mocha, Sillitoe and Perelló, 2005) or to the late Eocene-early Oligocene belt (Yabricoya, Sillitoe, 1981; Sillitoe and Perelló, 2005) (Fig. 1b). The Patricia mineralization was identified in 2006 during the early stages of exploration carried out by Herencia Resources Plc over historical mine workings that date back to the nineteenth century. These historic workings focused on silver mining and consist of more than $1800 \mathrm{~m}$ of underground galleries; a $400 \mathrm{~m}$ long gallery intersected several major $\mathrm{Zn}-\mathrm{Pb}-\mathrm{Ag}$ mineralized veins. The Patricia ore deposit forms part of the Paguanta Mining Exploration Project and represents the only example known to date of economic $\mathrm{Zn}-\mathrm{Pb}-\mathrm{Ag}$ epithermal in the northernmost part of the Chilean late Eocene - Oligocene metallogenic belt, although other polymetallic epithermal deposits within the belt occur further south in the Antofagasta region (e.g. Faride, Camus and Skewes, 1991). The scarcity of this 
type of ore deposits in the Tarapacá region contrasts with the large number of examples known in the Peruvian and Bolivian Andes such as Caylloma and Pallancata in Peru (Echavarría et al., 2006; GamarraUrrunaga et al., 2013) and San Cristóbal in Bolivia (Phillipson and Romberger, 2004).

From a metallogenic point of view, the interest of the Patricia deposit is double. The polymetallic features of the Patricia mineralization, closer to those of the Peruvian and some Bolivian epithermal deposits than to the Chilean ones, may be indicating a change in the style of outcropping deposits and/or the level of erosion of the porphyry-epithermal systems in this area. On the other hand, the well-known genetic and spatial relationships between porphyry and epithermal deposits as parts of larger magmatichydrothermal ore systems (i.e. White and Hedenquist, 1995; Seedorff et al., 2005; Simmons et al., 2005; Sillitoe, 2010) highlight the potential of the region for finding hidden deposits in a sector of the Andean late Eocene-early Oligocene metallogenic belt apparently devoid of them.

In this contribution we describe a detailed study of the geology, mineralogy, geochemistry, and fluid inclusions at the $\mathrm{Zn}-\mathrm{Pb}-\mathrm{Ag}$ Patricia ore deposit. A major emphasis of the work has been to define the tectonic and structural framework of the deposit, and to identify and characterize the different stages of mineralization regarding both the mineralogy of the economic phases and the nature of the fluids responsible for ore deposition. The results allow us to address some key questions related to the evolution of the hydrothermal system, the mechanisms of ore deposition, and the potential of the area for discovery of new reserves in the future.

\section{Regional context of the Paguanta Mining Exploration Project}

The Paguanta Mining Exploration Project, led by Herencia Resources Plc, is located at an elevation of approximately $3600 \mathrm{~m}$ above sea level on the Quebrada of Tarapacá, a deep valley that runs through the Precordillera and the piedmont of the Andean Western Cordillera (Fig. 1b). In structural terms, the Precordillera is characterized in this area by the development of a west vergent fault system and associated folds (Pinto et al., 2004; Victor et al., 2004; Farías et al., 2005) corresponding to the southward continuation of the west vergent thrust system observed at the latitude of Arica. This major tectonic feature was likely associated with shortening and uplift of this part of the Andes during the Cenozoic, Incaic and Quechua phases of the Andean cycle (see discussion by García and Hérail, 2001 and Wörner 
and Seyfried, 2001). A thick sequence of clastic deposits and ignimbrites was also sourced in this part of the uplifting Precordillera during Oligocene and Miocene times (Schlunegger et al., 2010). These sediments unconformably overlie an early Palaeozoic to Palaeocene substratum.

At the regional scale, Mesozoic rocks are dominated by Cretaceous green-grey to black andesitic terrestrial sediments and subaerial lavas (Cerro Empexa and Cauquima Formation; Galli and Dingman, 1962; Sayes, 1978) which unconformably overlie Jurassic marine to subaerial sediments and volcanic sedimentary strata (Galli, 1957; Pacci et al., 1980; Tomlinson et al., 2001). These formations were intruded by Late Cretaceous to Paleogene granitoid stocks (Thomas, 1967; Galli, 1968) (Fig. 1b) and were deformed during the Incaic phase of the Andean orogenic cycle (Noble et al., 1979). Following this deformation event, an Oligo-Miocene succession consists of thick sequences of ignimbrites and gravels (Altos de Pica, Luja and Guaviña formations; Galli, 1957; Galli and Dingman, 1962; Pacci et al., 1980; Tomlinson et al., 2001). North-trending faults are the dominant structures (Fig. 1b), delimiting the horsts of the Sierra Juan de Morales and Sierra de Tarapacá (Galli, 1968) to the north of Yabricoya area. The Palaeozoic and Mesozoic basement has experienced continuous uplift between these faults since the initial Incaic Phase and subsequent Miocene uplift of the Altiplano. The area is incised by numerous west-southwest trending valleys (Fig. 1b), among which the Quebrada de Tarapacá (Bouzari and Clark, 2002) exposes the volcanic rocks hosting the Patricia ore deposit.

The Paguanta Mining Exploration Project includes a proven economic deposit (Patricia) and two prospects (La Rosa and Doris) in an area of around $40 \mathrm{~km}^{2}$ (Fig. 2a). Patricia is an economic $\mathrm{Zn}-\mathrm{Pb}-\mathrm{Ag}$ vein-type mineralization containing mainly pyrite, sphalerite, galena and Ag-sulfosalts and hosted by hydrothermally altered andesitic rocks of uncertain age. Estimated mineral resources are $4.53 \mathrm{Mt}$, grading $3.7 \% \mathrm{Zn}, 1.3 \% \mathrm{~Pb}, 83 \mathrm{~g} / \mathrm{t} \mathrm{Ag}$ and $0.2 \mathrm{~g} / \mathrm{t} \mathrm{Au}$ using a $2 \% \mathrm{Zn}$ cut-off grade (June 2012, www.herenciaresources.com). The La Rosa prospect, located to the north of Patricia, consists of an intensely leached area with argillic alteration that extends to the Patricia area and is likely part of the same mineralizing system. The extension of the La Rosa prospect is well defined by a strong geophysical anomaly obtained through airborne gravimeters and covering more than $3 \mathrm{~km}^{2}$. In spite of intense weathering, rocks have anomalously high contents of lead $(0.41 \%)$, zinc $(1.06 \%)$, copper $(0.04 \%)$, gold 
$(0.22 \mathrm{~g} / \mathrm{t})$ and silver $(15.6 \mathrm{~g} / \mathrm{t})$. The Doris prospect is located north-northeast of Patricia and consists of a strongly altered zone with fractures filled with secondary copper minerals, mostly chrysocolla and malachite (Roel et al., 2013). Several sections of drill holes returned up to $2.5 \% \mathrm{Cu}$ and $50 \mathrm{~g} / \mathrm{t} \mathrm{Ag}$.

The country rocks in the Paguanta area are mostly volcanic and volcano-clastic in nature, probably correlative of the Cretaceous Cerro Empexa and Cauquima Formation (Galli and Dingman, 1962; Sayes, 1978). They exhibit a relatively complex structure of NW-SE- oriented asymmetrical folds. Detachment and fault-propagation types are present, the latter associated with steeply dipping sinistral thrust faults, which generally suppress a large part of the anticlinal short limbs. Folds and thrusts show vergence to both the SW and NE, suggesting the existence of flower structures at various scales. At the kilometer scale, the overall NW-SE orientation of folds and faults in the Paguanta area swings to more northerly orientations towards the north (Fig. 2a), suggesting it may represent the western part of a sinistral strikeslip duplex structure. This would be compatible with its location within the regionally important Domeyko fault system, a largely sinistral transpressional belt that has been active since ca. 35 Ma ago (Fig. 1b), a period during which $37 \mathrm{~km}$ of accumulated sinistral displacement has been estimated (Dilles et al., 1997; Tomlinson and Blanco, 1997b; Maksaev and Zentilly, 1999; Campbell et al., 2006).

\section{Analytical methods}

In order to carry out mineralogical, geochemical and fluid inclusion studies, representative samples were selected from 206 exploration cores drilled by Herencia Resources Plc and from surface exposures. Detailed logging of more than 200 meters of 12 drill cores (8 in the eastern block and 4 in western block, see below) was performed to determine vein mineral relationships, textures and hydrothermal alteration patterns. A total of 221 polished thin sections were prepared and studied by transmitted and reflected light optical microscopy. Most of them correspond to the eastern block where the mineralization is better developed.

A semi-quantitative determination of the mineralogy of host rocks and mineralized veins was performed by X-ray diffraction (XRD) using a Siemens D500 XRD diffractometer with Cu K $\alpha$ radiation and a graphite monochromator. The bulk mineralogy was studied in non-oriented powders and clay minerals in oriented aggregates prepared with the $<2 \mu \mathrm{m}$ fraction. The $<2 \mu \mathrm{m}$ clay fraction was 
sedimented from an aqueous suspension according to Stokes law (Moore and Reynolds, 1989). These oriented aggregates were air dried, treated with ethylene glycol and heated to $550{ }^{\circ} \mathrm{C} / 2 \mathrm{~h}$ and then analyzed. Random powders were scanned from 2 to $65^{\circ}$ and oriented aggregates were scanned from 2 to $30^{\circ} 2 \theta$ with a scan speed of $0.02^{\circ} 2 \theta / \mathrm{s}$.

The chemical compositions of ore minerals including base metal sulfides and Ag-bearing phases were determined by electron microprobe in 73 samples using a JEOL Superprobe JXA-8900 at the Centro Nacional de Microscopía Electrónica of the Universidad Complutense of Madrid, and a CAMECA Electron Microprobe Analyzer SX-50 at the Serveis Cientifico-tècnics of the Universitat of Barcelona. K $\alpha$ X-ray lines were measured for: $\mathrm{S}, \mathrm{As}, \mathrm{Fe}, \mathrm{Co}, \mathrm{Ni}, \mathrm{Cu}, \mathrm{Zn}, \mathrm{Ag}, \mathrm{Au}, \mathrm{Cd}, \mathrm{Sb}, \mathrm{Te}, \mathrm{Pb}$ and $\mathrm{Bi}$. The accelerating voltage was $20 \mathrm{kV} ; 50 \mathrm{nA}$ beam current and $1-5 \mu \mathrm{m}$ beam diameter. Counting times ranged from 20 to 60s. The following standards were used: Galena, GaAs, Fe, NiCrCo, Cu, $\mathrm{Zn}, \mathrm{Ag}, \mathrm{Au}, \mathrm{Cd}$, GaSb, Te and Bi from the Smithsonian Institution and Harvard University (Jarosewich et al., 1980; McGuire et al., 1992).

Ten representative vein samples containing base metal sulfides and Ag-bearing phases were analyzed for whole-ore composition in Genalysis Laboratory Services Pty. Ltd., Maddington (Australia). Ag, As, $\mathrm{Bi}, \mathrm{Cd}, \mathrm{Co}, \mathrm{Mo}$, Se and Te contents were measured by inductively coupled plasma mass spectrometry (ICP-MS, multi-acid digest); $\mathrm{Cu}, \mathrm{Pb}$ and $\mathrm{Zn}$ contents by inductively coupled plasma atomic emission spectrometry (ICP-OES, multi-acid digest); Au content by inductively coupled plasma mass spectrometry (ICP-MS, lead collection fire assay) and S content by infrared spectrometry. Linear regression and correlation between pairs of elements were computed using robust methods. These mathematical methods are appropriate for estimating correlation coefficients when samples are heterogeneous and the assumptions of normality and homoscedasticity required by classical statistical procedures cannot be guaranteed. Moreover, these methods are less influenced by anomalous data (outliers) than other classical methods. We computed correlation coefficients and p-value of the linear regression model with the lmrob function of the $\mathrm{R}$ package robustbase. The lmrob function uses fast MM-type estimators for linear regression models (Maronna et al., 2006). 
Fluid inclusion chips were prepared from 13 core samples located between $94 \mathrm{~m}$ (lower limit of the superficial oxidized zone) and $230 \mathrm{~m}$ (lower depth reached by drilling) below present surface. The study of 108 fluid inclusions contained in 26 FIAs in these samples consisted of petrographic observations and microthermometric, laser ablation inductively coupled plasma mass-spectrometry (LA-ICP-MS) analyses and Raman spectroscopic analysis. Samples were selected in the Catedral vein drill cores as it is the largest and the best drilled vein in the deposit. This allowed a thorough sampling both at different depths (in order to check the occurrence of boiling) and along the vein strike. Besides the sample position in the deposit, the main criterion was selecting samples where quartz and/or sphalerite were well represented. This study was carried out in the Fluid Inclusions Laboratories of the Department of Crystallography and Mineralogy at the Complutense University of Madrid (Spain) and Virginia Tech in Blacksburg (USA). Fluid inclusion assemblages (FIAs) representing groups of inclusions that were trapped simultaneously (Bodnar, 2003; Goldstein and Reynolds, 1994) were identified based on detailed petrographic observations. Heating-freezing measurements were made on previously defined FIAs. Fluid inclusion homogenization and final ice melting temperatures were obtained using a Linkam heating-freezing stage (THMS600) mounted on an Olympus microscope. Salinity was calculated from final ice melting temperatures using the equation of Bodnar (1993) for the $\mathrm{NaCl}-\mathrm{H}_{2} \mathrm{O}$ system. The stage was calibrated using synthetic fluid inclusion standards (Sterner and Bodnar, 1984). The precision and accuracy of measured homogenization temperatures are estimated to be $\pm 1.0 \mathrm{C}$ and the precision and accuracy of icemelting temperatures are estimated to be $\pm 0.1 \mathrm{C}$.

The elemental concentrations of 46 individual fluid inclusions were measured using laser ablationinductively coupled plasma-mass spectrometry (LA-ICP-MS). The LA-ICP-MS equipment consists of a $193 \mathrm{~nm}$ GeoLasPro Excimer Laser Ablation system coupled to an Agilent 7500ce inductively coupled plasma mass spectrometer. Fluid inclusions were ablated with a laser beam diameter selected such that the inclusion was wholly encompassed within the ablation pit. A NIST610 glass standard was analyzed before and after each sample for calibration and to correct for drift. For all inclusions, we analyzed for Au (dwell time: 50 milliseconds), Ag (dwell time: 30 milliseconds), Al, As, B, Ca, Cd, Cu, Fe, Ge, K, Mg, $\mathrm{Na}, \mathrm{Pb}, \mathrm{Sb}, \mathrm{Se}, \mathrm{Si}, \mathrm{Re}, \mathrm{Te}$ and $\mathrm{Zn}$ (dwell time: 10 milliseconds). Data processing was carried out using the 
AMS software (Mutchler et al., 2008). Ag, As, Au, Cd, Cu, Re and Te concentrations were less than their detection limits in all analyzed samples with detection limits at $1 \mathrm{ppm}$. Qualitative element compositions of the host mineral were also indirectly obtained during ablation to intercept fluid inclusions.

Raman analyses were performed using a laser Raman micro-probe based on the Horiba LabRamHR800 design with a high-resolution 800-mm spectrograph and equipped with an air-cooled 514-nm (green) argon laser set at $50 \mathrm{~mW}$ for excitation. The goal of the Raman analysis was to test for the presence of $\mathrm{CO}_{2}$ and to identify clay minerals in fluid inclusions. Data management and analysis were performed using the statistical software R 3.1.2 (R Core Team 2014).

\section{The Patricia $\mathrm{Zn}-\mathrm{Pb}-\mathrm{Ag}$ ore deposit}

The Patricia ore deposit crops out in a small area of $\sim 2 \mathrm{~km}^{2}$ in which the following lithological units can be distinguished (Figs. $2 \mathrm{~b}-3 \mathrm{a})$ :

1) Pre-mineralization units consist of: (1.1) a lower sedimentary succession which is represented by tightly folded and subvertical shales, sandstones and quartz-arenites, located NE of the Patricia mineralization and probably correlative to the Jurassic Noasa Formation elsewhere (Harambour, 1990); and (1.2) an upper volcano-sedimentary unit which hosts the Patricia mineralization and consists of a succession of subaerial, andesitic volcanic rocks, including breccias, pyroclasts, agglomerates, tuffs, lapilli and lavas, commonly affected by regional pervasive propylitic alteration. The volcano-sedimentary unit is folded and fractured along northwest-trending faults. The age of these rocks is uncertain, although a correlation with the Cretaceous Cerro Empexa and Cauquima Formations has been suggested (Galli and Dingman, 1962; Sayes, 1978).

2) Apart from slope debris, post-mineralization units are mainly represented by: (2.1) an ignimbrite sequence which unconformably overlies the folded volcano-sedimentary unit and the Patricia ore deposit at its southern end; and (2.2) a non-consolidated polygenic breccia that hosts variably-sized heterogeneous blocks of ignimbrite, andesite, quartzite, porphyritic rocks, hematite ore and granitoids.

Four main E-W- to ENE-WSW-oriented mineralized vein systems are recognized in the area, named from north to south, Campamento, Central, Catedral (Fig. 2b - 3a) and Carlos. These vein systems are 
better developed in the eastern part of the deposit (Fig. 2b) and they range in thickness from 1 to 100 meters in the Catedral vein and from 1 to 15 meters in the Campamento, Central and Carlos veins. The vein length at surface varies from $400 \mathrm{~m}$ for the Central vein to around $600 \mathrm{~m}$ for the Catedral and Campamento veins, whereas the Carlos vein does not crop out and is only observed in drill cores. The vein systems generally thin out towards both the east and west from a thicker central zone where the historical and present mine workings are concentrated. Internally, these vein systems consist of stockworks with veinlets from 1 to $10 \mathrm{~cm}$ wide, striking NW-SE, NE-SW and E-W, and mostly showing steep inclinations although some gently dipping veinlets are also locally recognized. E-W veinlets are thicker than other veinlets in the stockwork and this is consistent with the E-W orientation of the four major mineralized veins. These structural features of the mineralization within the dominant northwesttrending fault system (Fig. 2b) indicate that the Patricia ore deposit was emplaced under a sinistral strikeslip regime, probably as a part of an extensional (transtensional) duplex.

At the deposit scale, the area is transected by a prominent tectonic structure represented by a set of parallel NNW-SSE thrust faults that post-date the mineralization, the most important of which is partly exposed along an overhanging cliff close to the mining camp (Fig. 2b-3a). Kinematic indicators show reverse fault movement. However, a mineralized stockwork area connects the Campamento and Catedral veins along these faults in the central part of the deposit (Fig. 2b), thus suggesting that these NNW-SSE structures were already active during the mineralization event, although not necessarily as thrust faults. The thrust set structure divides the area into different blocks, with the eastern blocks always in the hanging-wall. The easternmost block has steep relief and is characterized by a well-developed silicified lithocap with intense oxidized-vein stockwork and locally vuggy silica textures at the surface (Fig. 3b-c). Unmineralized silicification halos typically surround the outcropping mineralized veins (Fig, 2b) and extend to $\sim 30 \mathrm{~m}$ below the surface, according to drill core observations. The western blocks commonly show less steep slopes and are characterized by an intense weathering and argillic alteration associated with oxidized vein systems at the surface (Fig. 3d). Mineralized veins are here thinner and poorer in their metal contents, although silicification and stockwork structures are also present but to a lesser extent. The 
occurrence of chert, amorphous silica, jasperoids and calcite in or close to the surface is also common in the westernmost part of the deposit (Fig. 3e-f).

The host rocks are affected by locally intense hydrothermal alteration close to the mineralized veins. This alteration is superimposed on the earlier regional propylitic alteration (Fig. 4a). As a consequence, primary textures are poorly preserved. Hydrothermal alteration includes chloritization (chlorite \pm pyrite \pm arsenopyrite \pm apatite \pm rutile, Fig. 4 b) and sericitization (quartz + sericite/illite \pm pyrite \pm kutnohorite, Fig. 4c). The chloritic alteration gives rise to a distinctive pale-green colors that is pervasive and results in complete transformation of mafic minerals and plagioclase to chlorite (chamosite and clinochlore) along with minor formation of pyrite, arsenopyrite, apatite and rutile. Pyrite and arsenopyrite occur as disseminations of euhedral to subhedral crystals $(0.5-3 \mathrm{~mm})$ throughout the host volcanic rock (Fig. $4 \mathrm{~b})$. The sericitic alteration surrounds and partially overprints the chloritic alteration (Fig. 4c). Chlorite and illite also occur within the veins in contact with ore minerals.

\section{Mineralogy of the ore deposit}

\subsection{Mineral assemblages and paragenetic sequence}

Ore minerals in the Patricia ore deposit consist, in decreasing order of abundance, of: pyrite, sphalerite, galena and arsenopyrite, minor amounts of chalcopyrite, pyrrhotite and Ag-bearing minerals (freibergite, polybasite, stephanite, pyrargyrite, freieslebenite and acanthite) and trace amounts of boulangerite $\left(\mathrm{Pb}_{5} \mathrm{Sb}_{4} \mathrm{~S}_{11}\right)$ and jamesonite $\left(\mathrm{Pb}_{4} \mathrm{FeSb}_{6} \mathrm{~S}_{14}\right)$. Representative chemical compositions of sulfide phases and Ag-bearing minerals are given in Tables 1 and 2. Based on ore mineralogy and textures, several distinct veins have been identified (Fig. 5): (a) symmetric mineralized veins composed mainly of pyrite \pm arsenopyrite on the edges, quartz in the outer bands and sulfides, with chlorite \pm kutnohorite in the center (Fig. 5a); (b) asymmetric veins with sphalerite, arsenopyrite and quartz (Fig. 5b); (c) brecciated sulfides cemented by quartz and arsenopyrite (Fig. 5c); (d) veinlets (from 0.1 to $5 \mathrm{~cm}$ ) of pyrite and sphalerite (Fig. 5d); (e) massive veins of sulfides (Fig. 5e); and (f) veinlets (from 0.5 to $3 \mathrm{~cm}$ ) composed of quartz and pyrite \pm arsenopyrite (Fig. 5f). Based on the different vein types and the textural relationships between them, three mineralization stages (pre, main, and post-ore stages) have been established (Fig. 6). 


\subsubsection{Stage 1: Pre-ore stage}

The stage 1, or pre-ore stage, is characterized by the deposition of quartz $\left(\mathrm{Qz}_{1}\right)$, pyrite $\left(\mathrm{Py}_{1}\right)$ and minor arsenopyrite $\left(\mathrm{Apy}_{1}\right)$ in veins that may be later filled by sphalerite and galena during the main stage of mineralization (Figs. 5a and 7a), suggesting a successive re-opening of veins. At the contact with the host rock, $\mathrm{Qz}_{1}$ occurs as fine-grained crystals $(<0.5 \mathrm{~mm})$ that grow to elongated and larger crystals (>2mm) towards the vein center, developing comb textures typical of open-space filling (Fig. 7b). Py, the main sulfide of the stage 1, occurs as euhedral to subhedral crystals $(0.5-1.5 \mathrm{~mm})$ distributed mainly along the boundaries of the veins (Figs. 7a and 7c) and also as individual euhedral grains in the central part of the veins filled with Qz $\mathrm{z}_{1}$ (Fig. 5f). Py $\mathrm{y}_{1}$ is typically zoned with As-rich bands (up to 1.5 at. \% As) (Fig. 7d). In these zoned grains, $\mathrm{S}$ is negatively correlated with $\mathrm{As}$ and $\mathrm{Sb}$ whereas As is positively correlated with $\mathrm{Sb} . \mathrm{Py}_{1}$ is selectively replaced by sphalerite and galena of the main stage (Fig. 7e). Apy occurs as euhedral to subhedral grains $(0.5-1 \mathrm{~mm})$ in close spatial relationship with $\mathrm{Py}_{1}$ and usually shows zoned crystals with Sb-rich bands (up to 5.2 at. \% Sb) (Fig. 7f). The As content in $\mathrm{Apy}_{1}$ ranges from 26.9 to 33.9 at. \%. The Sb content is positively correlated with As and negatively correlated with S.

\subsubsection{Stage 2: Base-metal and Ag stage}

The stage 2, or base-metal and Ag stage, represents the highest volume of mineralization in the Patricia ore deposit. During this stage, base metal sulfides and Ag-bearing minerals precipitated in symmetric (Fig. 5a), asymmetric (Fig. 5b) and massive veins (Fig. 5e). This stage can be divided into two substages (Fig. 6): substage $2 \mathrm{~A}$ is characterized by sphalerite $\left(\mathrm{Sp}_{2 \mathrm{~A}}\right)$ and minor amounts of chalcopyrite and pyrrhotite, while substage 2B is characterized by abundant brecciation (Fig. $5 \mathrm{c}$ ) and the precipitation of sphalerite $\left(\mathrm{Sp}_{2 \mathrm{~B}}\right)$ and galena $\left(\mathrm{Gn}_{2 \mathrm{~B}}\right)$ and minor chalcopyrite, pyrrhotite and Ag-bearing phases, including freibergite, pyrargyrite, polybasite, stephanite, freieslebenite and acanthite. Minor quartz and pyrite are occasionally observed in this stage. $\mathrm{Sp}_{2 \mathrm{~A}}$ occurs as massive aggregates ( 0.5 to $>2 \mathrm{~mm}$ ) of zoned crystals, locally forming banded sphalerite (Fig. 8a-b). $\mathrm{Zn}$ and Fe contents of $\mathrm{Sp}_{2 \mathrm{~A}}$ range from 37.9 to 45.9 at. $\%$ and from 3.2 to 10.9 at $\%(6.4-17.6 \mathrm{~mol} . \% \mathrm{FeS})$, respectively. $\mathrm{Sp}_{2 \mathrm{~B}}$ also occurs as coarse to fine-grained aggregates $\left(<0.5\right.$ to $>2 \mathrm{~mm}$ ) of zoned crystals. In contrast to $\mathrm{Sp}_{2 \mathrm{~A}}, \mathrm{Sp}_{2 \mathrm{~B}}$ hosts numerous blebs of chalcopyrite ("chalcopyrite disease") and pyrrhotite and is in close spatial relationship to galena $\left(\mathrm{Gn}_{2 \mathrm{~B}}\right)$ 
and Ag-bearing minerals (Fig. $8 \mathrm{c}-\mathrm{d}$ ). $\mathrm{Sp}_{2 \mathrm{~B}}$ has contents of $\mathrm{Zn}$ and $\mathrm{Fe}$ similar to $\mathrm{Sp}_{2 \mathrm{~A}}(39.3-44.8$ at. $\% \mathrm{Zn}$ and 4.2-9.4 at. \% Fe) with Fe ranging from 7.7 to 15.5 mol.\%. The Cd content in both types of sphalerite is typically less than 0.2 at. \% and does not show any correlation with $\mathrm{Zn}$. $\mathrm{Gn}_{2 \mathrm{~B}}$ usually fills voids within $\mathrm{Sp}_{2 \mathrm{~B}}$ grains (Figs. 8d-8e). The $\mathrm{Pb}$ content ranges from 47.9 to 51.7 at. $\%$ and $\mathrm{Ag}$ content is invariably below the detection limit of the EPMA. $\mathrm{Gn}_{2 \mathrm{~B}}$ contains significant amounts of $\mathrm{Sb}$, usually higher than 0.2 at. $\%$ and up to 0.67 at. \%, but no significant correlation between $\mathrm{Sb}$ and $\mathrm{Pb}$ contents is observed. Chalcopyrite and pyrrhotite mainly occur as inclusions or blebs $(<50 \mu \mathrm{m})$ within $\mathrm{Sp}_{2 \mathrm{~B}}($ Fig. $8 \mathrm{c}-\mathrm{d})$, and also as individual grains $(10-100 \mu \mathrm{m})$ filling voids between $\mathrm{Sp}_{2 \mathrm{~B}}$ and $\mathrm{Gn}_{2 \mathrm{~B}}$ in close spatial relationship with Ag-bearing minerals. Pyrrhotite is Fe-poor with an average Fe content of 46.1 at. \%. Furthermore, Fe-rich chlorite and illite occur in close association with sphalerite and galena within mineralized veins (Fig. 8f). Fe-rich chlorite is more abundant than illite that occurs as small crystals intergrown with Fe-rich chlorite. These chlorites are systematically of chamositic type with Fe content up to 46.4 at. \%. The presence of chlorite and illite may provide useful information about the $\mathrm{pH}$ of fluids (e.g Romberger, 1991; Moncada and Bodnar, 2012) and the existence of different mineralizing fluids.

\subsubsection{Stage 3: Post-ore stage}

The stage 3, or post-ore stage, is characterized by: (a) the formation of quartz $\left(\mathrm{Qz}_{3}\right)$ and arsenopyrite $\left(\mathrm{Apy}_{3}\right)$ cementing brecciated sulfides of the second stage (Figs. 5c-9a); (b) small veinlets $(0.2-5 \mathrm{~cm})$ of pyrite $\left(\mathrm{Py}_{3}\right)$ and sphalerite $\left(\mathrm{Sp}_{3}\right)$ forming local stockwork (Fig. 5d) and (c) the late formation of kutnohorite. During the post-ore stage, minor galena $\left(\mathrm{Gn}_{3}\right)$, Ag-bearing phases (freibergite, pyrargyrite, freieslebenite and acanthite) and $\mathrm{Pb}$ sulfosalts (boulangerite and jamesonite) have also precipitated. In the contact with brecciated sulfides, $\mathrm{Qz}_{3}$ occurs as microcrystalline crystals $(<0.2 \mathrm{~mm})$ whereas outwards it forms large mosaic-textured crystals (from 0.5 to $>5 \mathrm{~mm}$ ) (Fig. 9b) and small geodes indicating open-

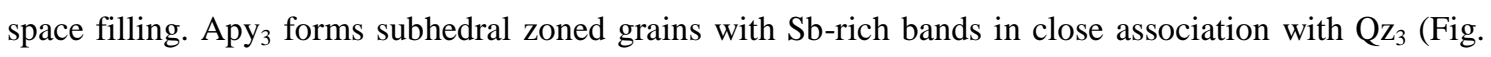
9c-d). In contrast to $\mathrm{Apy}_{1}$, the As content of $\mathrm{Apy}_{3}$ shows a narrow range (29.5-30.7 at. \%) and the Sb content of the Sb-rich bands is lower (up to 1.4 at. \%). Sb content is positively correlated with As and negatively correlated with $\mathrm{S}$. $\mathrm{Py}_{3}$ occurs as euhedral to anhedral crystals $(0.2-1 \mathrm{~mm})$ and usually contains As-rich bands (up to 1 at. \%). In these As-rich bands, S is also negatively correlated with As and Sb, and 
As is positively correlated with $\mathrm{Sb}$ as in $\mathrm{Py}_{1} . \mathrm{Sp}_{3}$ is similar to $\mathrm{Sp}_{1}$ and $\mathrm{Sp}_{2}$ and also occurs as massive aggregates of zoned crystals (Fig. 9e-f). $\mathrm{Zn}$ and $\mathrm{Fe}$ contents of $\mathrm{Sp}_{3}$ are also similar to those of $\mathrm{Sp}_{1}$ and $\mathrm{Sp}_{2}$, ranging from 40.8 to 44.9 at. $\%$ and from 3.9 to 7.8 at. \%, respectively (7.5-13.2 mol.\% FeS). The Cd content of $\mathrm{Sp}_{3}$ is less than 0.13 at. \% and does not correlate with $\mathrm{Zn} . \mathrm{Gn}_{3}$ occurs as minor aggregates and shows a narrow range in $\mathrm{Pb}$ content (46.3-48.6 at. \%) and contains significant amounts of $\mathrm{Sb}$ (average 0.4 at. \% and up to 1.9 at. \%). The $\mathrm{Ag}$ content, in most analyzed $\mathrm{Gn}_{3}$ grains, is below the detection limit of the EPMA. Freieslebenite, boulangerite and jamesonite, with grain sizes ranging from 5 to $25 \mu \mathrm{m}$, occur in close relationship with Ag-bearing minerals and filling voids within $\mathrm{Gn}_{3}$ (Fig. 9h). Kutnohorite, interpreted as the last mineral that precipitated in the paragenetic sequence, occurs as euhedral and subeuhedral grains forming narrow veins that cross-cut the brecciated sulfides of the second stage (Fig. $9 \mathrm{~g}$.

\subsection{Mineralogy and chemistry of Ag-bearing minerals}

A total of 230 grains of Ag-bearing phases were identified and analyzed in 30 polished thin sections. Ag-bearing minerals are present in substage 2B in close textural relationship to galena (more than $80 \%$ of the Ag-bearing minerals are located within galena), sphalerite and chalcopyrite and also in the post-ore stage in close relationship to kutnohorite and minor sulfides. The Ag-bearing minerals identified are, in decreasing order of abundance, freibergite, polybasite, stephanite, pyrargyrite, freieslebenite and acanthite. They regularly occur as anhedral grains ranging in size from less than $10 \mu \mathrm{m}$ up to $200 \mu \mathrm{m}$, but average around $40 \mu \mathrm{m}$ and usually are located at the boundaries of galena and sphalerite or close to the contact with sphalerite, chalcopyrite and pyrite (Fig. 10). Representative analyses of different Ag-bearing phases are reported in Table 2.

Freibergite $(\mathrm{Ag}, \mathrm{Cu})_{10}(\mathrm{Fe}, \mathrm{Zn})_{2} \mathrm{Sb}_{4} \mathrm{~S}_{13}$ represents $90 \%$ of the total Ag phases identified. It occurs as anhedral grains $(15-500 \mu \mathrm{m}$ but commonly $<60 \mu \mathrm{m})$ located at the boundaries of $\mathrm{Gn}_{2 \mathrm{~B}}$ and $\mathrm{Sp}_{2 \mathrm{~B}}$ grains and close to the contact with pyrite, chalcopyrite, silicates and kutnohorite (Fig. 10a-b). The Fe and Zn content in individual grains of freibergite is homogeneous and has an Fe content systematically higher than $\mathrm{Zn}$. Ag ranges from 11 to 21.7 at. \% with an average of 15.1 at. \%, and $\mathrm{Cu}$ ranges from 13.3 to 23.9 at. \% with an average of 19.4 at. \%. Arsenic content is invariably below 0.2 at. \%. 
Polybasite (Ag, $\mathrm{Cu})_{16}(\mathrm{Sb}, \mathrm{As})_{2} S_{11}$ typically forms fine-grained crystals (10-60 $\left.\mu \mathrm{m}\right)$ intergrowth with freibergite (Fig. 10a) or elongated grains along cleavage planes within $\mathrm{Gn}_{2 \mathrm{~B}}$ crystals (Fig. 10c). Unlike freibergite, polybasite is invariably contained within galena and has not been observed within sphalerite. Electron microprobe analyses reveal that $\mathrm{Ag}$ content ranges from 46.9 to 49.8 at. \% with minor substitution by $\mathrm{Cu}$ (up to $1.5 \mathrm{apfu}$ ). Sb content ranges from 5.6 to 8.7 at. \% and As content is below 0.3 at. $\%$.

Pyrargyrite $\left(\mathrm{Ag}_{3} \mathrm{SbS}_{3}\right)$ occurs as anhedral grains $(5-40 \mu \mathrm{m})$ disseminated within $\mathrm{Gn}_{2 \mathrm{~B}}, \mathrm{Gn}_{3}$ and commonly in close relationship with kutnohorite (Fig. 10d). It is particularly common in samples with high modal abundance of Ag-bearing minerals. Its composition is almost stoichiometric with Ag content around 43.7 at. $\%$.

Stephanite $\left(\mathrm{Ag}_{5} \mathrm{SbS}_{4}\right)$ is a very minor Ag-rich sulfosalt in the Patricia ore deposit and commonly coexists with polybasite and freibergite with grain sizes of up to $30 \mu \mathrm{m}$. It contains $53.7-55.7$ at. $\% \mathrm{Ag}$ and up to 3 at. $\% \mathrm{Cu}$.

Freieslebenite $\left(\mathrm{AgPbSbS}_{3}\right)$ forms small-elongated 30 to $200 \mu \mathrm{m}$ grains within galena (Fig. 10e), and it is also in close relationship to other $\mathrm{Pb}$ sulfosalts such as boulangerite and jamesonite. $\mathrm{Ag}$ and $\mathrm{Pb}$ contents range from 16.9 to 19 at. \% and from 12.4 to 12.7 at. $\%$, respectively.

Acanthite $\left(\mathrm{Ag}_{2} \mathrm{~S}\right)$ represents the most Ag-rich mineral (from 60 to 71.1 at. \%) found in the Patricia ore deposit. However, it is a very minor phase and usually occurs as anhedral 5 to $10 \mu \mathrm{m}$ grains, closely related to freibergite and pyrargyrite (Fig. 10f). It is also observed at the boundaries between sphalerite and galena or in close relationship to kutnohorite.

\section{Whole-ore composition of the mineralized veins}

Results of multi-element analyses for selected ore samples are given in Table 3. Matrices of statistically significant correlations and scatterplots for pairs of elements in whole-ore samples are given in Fig. 11. According to the p-value of the robust linear regression, analyzed metals can be classified into two groups. The first group is comprised of the metals positively correlated with $\mathrm{Ag}$, namely $\mathrm{Zn}, \mathrm{Pb}, \mathrm{Cu}$ and $\mathrm{Cd}$, and the second group by the metals positively correlated with $\mathrm{Au}$, namely $\mathrm{As}, \mathrm{Sb}, \mathrm{Ge}$ and W. No additional correlations have been observed between the remaining analyzed elements and the metals of 
both groups. The relative abundances of $\mathrm{Zn}$ and $\mathrm{Pb}$ can be expressed as simple ratios (e.g. $\mathrm{Pb} / \mathrm{Zn}$ ) or as the zinc ratio $100 * \mathrm{Zn} /(\mathrm{Zn}+\mathrm{Pb})$, defined by Huston and Large (1987) for massive sulfide systems. Huston et al. (2006) extended the use of this ratio to $\mathrm{Zn}-\mathrm{Pb}-\mathrm{Ag}$ ore deposits. According to these authors the zinc ratio is controlled mostly by metal solubilities in the ore fluid and the metal content of the source rocks, establishing relationships between temperature and salinity of the fluids and the zinc ratio of whole-ore composition. In the Patricia ore deposit, the zinc ratio of mineralized veins range from 37.3 in galena-rich samples to 92.8 in sphalerite-rich samples, although the average is 64.4 (standard deviation, 13.81). The $\mathrm{Ag}: \mathrm{Zn}$ ratio ranges from 0.001 to 0.016 with an average of 0.005 (1:206). The Au content is below $1 \mathrm{ppm}$ in all samples and the Ag:Au ratio ranges from 200 to 6000 (average, 1300).

\section{Fluid inclusions microthermometry and LA-ICP-MS}

Fluid inclusion assemblages (FIAs) have been studied in quartz from the pre-ore stage $\left(\mathrm{Qz}_{1}\right)$ and post-ore stage $\left(\mathrm{Qz}_{3}\right)$, and sphalerite $\left(\mathrm{Sp}_{2 \mathrm{~A}}\right.$ and $\left.\mathrm{Sp}_{2 \mathrm{~B}}\right)$ from the base-metal and $\mathrm{Ag}$ stage. According to Bodnar (2003) and Goldstein and Reynolds (1994) an FIA refers to a group of fluid inclusions that were all trapped at the same time. Assuming that all of the fluid inclusions within an FIA show the same room temperature phase ratios and microthermometric behaviour, one can assume that the inclusions record the original trapping conditions. Fluid inclusions at the Patricia deposit are systematically liquid-rich at room temperature and do not contain recognisable $\mathrm{CO}_{2}$. Both primary and secondary fluid inclusions have been identified in the system. Primary fluid inclusions are distributed along growth zones (Fig. 12a-c) and represent the fluid from which the host mineral precipitated. Secondary fluid inclusions (Fig. 12d) occur along fracture planes and represent fluids trapped after host-mineral precipitation. Fluid inclusions whose origin is not clearly primary or secondary have only been incorporated in the paragenesis when they show specific features that constrain the time of trapping (i.e. such as when a fluid inclusion forms around a chalcopyrite bleb within sphalerite, indicating that the inclusion and chalcopyrite are coeval; Fig. 12e).

7.1 Pre - ore stage. A total of 39 fluid inclusions (9 FIAs) were studied in $\mathrm{Qz}_{1}$ (Fig. 7b) located at the outer bands of symmetric mineralized veins. Fine-grained $\mathrm{Qz}_{1}$ crystals occurring at and close to the vein walls do not contain fluid inclusion suitable for being studied. Therefore, fluid inclusion data were obtained in $\mathrm{Qz}_{1}$ larger crystals occurring vein inwards as comb-type quartz grains and in close proximity 
to the stage 2 base-metal sulfides. Primary FIAs are scarce (Fig. 12a-b) whereas secondary trails of FIAs are common but the inclusions in the FIA are smaller than those in FIAs containing primary fluid inclusions (Fig. 12d). Salinities estimated from primary FIAs range from 22 to $6 \mathrm{wt} \% \mathrm{NaCl}$ and from secondary FIAs vary from 15 to $3 \mathrm{wt} \% \mathrm{NaCl}$. Homogenization temperatures (Th) from primary FIAs range from 236 to $205{ }^{\circ} \mathrm{C}$ and from 270 to $165^{\circ} \mathrm{C}$ for secondary FIAs (Table 4). Both primary and secondary FIAs frequently contain a fibrous mineral with distinct Raman peaks at 204, 262, 355, 395, 466, 698, 798 and $1167 \mathrm{~cm}^{-1}$, suggesting that the fibrous mineral is a hydrous phyllosilicate, interpreted as illite (Fig. 12b).

7.2 Base - metal and silver stage. A total of 62 fluid inclusions (13 FIAs) were studied in sphalerite, $\mathrm{Sp}_{2 \mathrm{~A}}$ and $\mathrm{Sp}_{2 \mathrm{~B}}$, of the substages $2 \mathrm{~A}$ and $2 \mathrm{~B}$, respectively. FIAs in $\mathrm{Sp}_{2 \mathrm{~A}}$ are common, usually showing elongated fluid inclusions along growth bands in zoned sphalerite (Fig. 12c). Primary fluid inclusions are usually larger than secondary inclusions, which commonly form trails cross-cutting growth bands within the $\mathrm{Sp}_{2 \mathrm{~A}}$. Salinities estimated from primary FIAs of substage $2 \mathrm{~A}$ range from 9 to $1 \mathrm{wt} \% \mathrm{NaCl}$ and for secondary FIAs from 4 to $3 \mathrm{wt} \% \mathrm{NaCl}$. Homogenization temperatures (Th) from primary FIAs range from 248 to $172^{\circ} \mathrm{C}$ and from 197 to $195^{\circ} \mathrm{C}$ for secondary FIAs (Table 4). FIAs in $\mathrm{Sp}_{2 \mathrm{~B}}$ were more difficult to study than those in $\mathrm{Sp}_{2 \mathrm{~A}}$, because $\mathrm{Sp}_{2 \mathrm{~B}}$ is more Fe-rich and darker, hindering the identification of fluid inclusions (Fig. 12e). Fluid inclusions observed in $\mathrm{Sp}_{2 \mathrm{~B}}$ are commonly associated with solid inclusion of minor sulfides such as chalcopyrite, pyrrhotite and Ag-bearing minerals (Fig. 12e). Salinity values from primary FIAs range from 10 to $2 \mathrm{wt} \% \mathrm{NaCl}$ and $\mathrm{Th}$ from 182 to $138^{\circ} \mathrm{C}$.

7.3 Post - ore stage. A total of 19 fluid inclusions (4 FIAs) were studied in large mosaic-textured $\mathrm{Qz}_{3}$ quartz crystals. Fluid inclusions were not observed in earlier microcrystalline $\mathrm{Qz}_{3}$ crystals. Primary fluid inclusions are observed in the growth bands of quartz but their dark colour makes them impossible to study (Fig. 12f). FIAs consisting of clear primary inclusions rarely occur (Fig. 12g). These fluid inclusion are commonly small $(\sim 10 \mu \mathrm{m})$, reporting salinity from 8 to 4 wt $\% \mathrm{NaCl}$ and $\mathrm{Th}$ ranging from 215 to $175^{\circ} \mathrm{C}$ (Table 4). Many secondary inclusions along fractures could be observed in Qz (Fig. 12h) but only some could be studied because of their small sizes. FIAs of secondary inclusions have lower 
salinity, ranging from 4 to $2 \mathrm{wt} \% \mathrm{NaCl}$ and $\mathrm{Th}$ ranging from 242 to $150{ }^{\circ} \mathrm{C}$ (Table 4 ). As observed in $\mathrm{Qz}_{1}$, these FIAs have also trapped illite crystals.

LA-ICP-MS analyses were carried out on 46 individual inclusions. Fluid inclusions in quartz (stages 1 and 3) contain measurable concentrations of $\mathrm{Na}$ and commonly contain measureable concentrations of $\mathrm{K}, \mathrm{Ca}, \mathrm{Al}$ and $\mathrm{Sb}$. However, $\mathrm{Al}$ and $\mathrm{Sb}$ concentrations may reflect contributions from the host quartz. Measurable concentrations of Fe are detected in 6 individual inclusions, and measurable concentrations of $\mathrm{Mg}, \mathrm{Zn}$ and $\mathrm{Pb}$ in 4 individual inclusions. $\mathrm{Ag}, \mathrm{As}, \mathrm{Au}, \mathrm{B}, \mathrm{Cd}, \mathrm{Cu}, \mathrm{Ge}, \mathrm{Re}, \mathrm{Se}$ and $\mathrm{Te}$ are below the detection limit in all fluid inclusion in quartz. The Na content ranges from 5 to 340 ppm for inclusions in quartz. In these inclusions, concentrations of Ca range from 2.2 to $183 \mathrm{ppm}, \mathrm{K}$ from 1.3 to $125 \mathrm{ppm}$ and Fe from 1 to $10 \mathrm{ppm}$. Strong correlation was observed between the Na content with $\mathrm{Ca}$, $\mathrm{K}$ and Fe contents and salinity calculated by microthermometry.

Fluid inclusions in sphalerite (stages $2 \mathrm{~A}$ and $2 \mathrm{~B}$ ) also contain measurable concentrations of $\mathrm{Na}$ and commonly contain measureable concentrations of $\mathrm{K}, \mathrm{Ca}, \mathrm{Cd}, \mathrm{Cu}, \mathrm{Fe}$ and $\mathrm{Zn}$. However, $\mathrm{Cd}, \mathrm{Cu}, \mathrm{Fe}$ and $\mathrm{Zn}$ concentrations may reflect contributions from the host sphalerite. Measurable concentrations of B (up to $14 \mathrm{ppm}$ ) are detected in 10 individual inclusions. $\mathrm{Ag}, \mathrm{Al}, \mathrm{As}, \mathrm{Au}, \mathrm{Ge}, \mathrm{Mg}, \mathrm{Pb}, \mathrm{Re}, \mathrm{Se}, \mathrm{Si}$ and $\mathrm{Te}$ are below the detection limit in all fluid inclusions in sphalerite. The Na content ranges from 3 to 73 ppm for inclusions in sphalerite. In these inclusions, concentrations of $\mathrm{Ca}$ and $\mathrm{K}$ range from 1.3 to $43 \mathrm{ppm}$ and from 1.2 to 23 ppm, respectively. Strong correlation was observed between the Na content with Ca and K contents and salinity calculated by microthermometry.

\section{Discussion}

\subsection{Tectonic framework}

The Patricia epithermal ore deposit was developed in an active tectonic system, as shown by its structural features and internal vein textures. The main faults in the area strike N10-30W, whereas the synthetic Riedel faults lie N50-70W. The extensional vector was located $\sim \mathrm{N}-\mathrm{S}$, as indicated by the mineralized structures occurring as parallel vein systems, E-W- to ENE-WSW-oriented, with stockwork veinlets occurring along NW-SE, NE-SW and E-W orientations. These features indicate that the mineralization formed under a sinistral strike-slip regime, which controlled the development of the 
mineralized structures and created open spaces where the mineralization was deposited. In fact, transtensive domains with pull-apart and generalized extensional structures are suggested, as shown by the infilling of veinlets of different orientations forming the stockwork. Furthermore, these veinlets were continuously formed and/or repeatedly opened during the mineralization process as indicated by different types of veinlets recognized in the deposit (Fig. 5), often showing open space filling textures, i.e. symmetrical banding, crustification, quartz comb structures, etc. A strike-slip structural framework has been also described in other epithermal deposits, such as the Pallancata deposit (Gamarra-Urrunaga et al., 2013) and the Shila-Paula district in Peru (Chauvet et al., 2006), the Faride deposit in the Antofagasta region, Chile (Camús and Skewes, 1991) and the Gandy and Abolhassani prospects in Iran (Shamanian et al., 2004). In these deposits, the kinematics of the strike-slip structures also controlled mineral deposition in parallel vein systems.

At a regional scale, the Patricia ore deposit is located in the Precordillera domain, which occupied the Andean back-arc region during the Cretaceous (Mpodozis and Ramos, 1990). The main contractional deformation event recorded in the Precordillera took place in the Eocene (Incaic Phase; Noble et al., 1979). This event was coeval with the initial formation of the still active Bolivian orocline (Isacks, 1988; Allmendinger, 2005; Arriagada et al., 2008; Capitanio et al., 2011), whose southern limb has since being subjected to clockwise rotation accommodated by sinistral strike-slip along trench-parallel fault systems, e.g. the Domeyko fault system. The Patricia deposit is located at the northern end of this fault system. These regional constraints are in agreement with the features observed at the Patricia deposit and in nearby rock units. The overall deformation of the host-rocks is compatible with the sinistral transpressional regime during the Incaic Phase in this part of the Andes. The sinistral regime that is also inferred from the structural characteristics of the deposit itself suggests that it may have formed during later, post-folding stages within the same Incaic Phase or, alternatively, during a post-Incaic event with similar kinematics. Whichever the case, the deposit was exhumed by the time of eruption of the ignimbrite sequence that unconformably overlies its southern part (Fig. 2b). In the absence of absolute ages for both the mineralization and the unconformable ignimbrites no further constraints on the timing are possible. However, the above discussion reinforces the inclusion of the Patricia deposit within the late 
Eocene-early Oligocene metallogenetic belt. This interpretation is supported by the Patricia geographical position (Fig. 1b), its proximity to the early Oligocene Queen Elizabeth porphyry copper deposit (Davidson y Mpodozis, 1991) and its genetic, geometrical and kinematic relationships to the Domeyko fault system, which is spatially and temporally coincident with the development of the metallogenic belt (Sillitoe and Perelló, 2005; Sillitoe, 2010; and references therein).

The Patricia ore deposit is divided along its central part into two blocks (eastern and western) separate from each other by a set of NNW-ESE-trending reverse faults. The kinematic movement on these faults resulted in uplift of the eastern block (Fig. 3a), exhuming thicker and deeper parts of the deposit, as confirmed by fluid inclusion data (see below). In contrast, a shallower part of the system is exposed in the western block as suggested by the occurrence of cherts, cryptocrystalline silica and jasperoids (Fig. 3e-f), which are absent in the eastern block. These siliceous formations are typical of thermal spring settings (Camprubí et al., 2006).

\subsection{Temperature and mechanisms of ore deposition}

Based on the internal textures of veinlets and cross-cutting relationships among them, three main mineralizing stages have been recognized in the Patricia deposit, with the second stage being the most economically significant. The paragenesis of each stage and the evolution of the mineralizing fluids (Fig. 13) both indicate changes in mineralizing conditions over time.

\subsubsection{Pre-ore stage}

The pre-ore stage is defined by an early quartz $\mathrm{Qz}_{1}$ coexisting with pyrite $\mathrm{Py}_{1}$ and arsenopyrite $\mathrm{Apy}_{1}$. Quartz grain size increases from vein walls inwards, where quartz crystals are often prismatic, thus indicating a progressive decrease in silica super saturation as precipitation of quartz proceeded. Primary fluid inclusions studied in coarse-grained $\mathrm{Qz}_{1}$ indicate a wide range of salinities, from high salinity close to the $\mathrm{NaCl}$ saturation at room temperature to $6 \mathrm{wt} \% \mathrm{NaCl}$, and homogenization temperatures from 236 to $205^{\circ} \mathrm{C}$. However, the lack of microthermometric data from fine-grained $\mathrm{Qz}_{1}$ does not allow knowing the fluid features during the early pre-ore stage. The salinity and temperature range obtained for the late pre-ore stage is in general agreement with fluid inclusion data from other intermediate sulfidation epithermal deposits (Bodnar et al., 2014). The observed salinity variation within this stage strongly 
suggests a process of mixing between brine and a more diluted fluid (Fig. 13).. This stage is similar to the initial stages in other epithermal deposits where quartz, pyrite \pm arsenopyrite are typically deposited during the earliest stages at the highest temperatures (e.g. El Bronce deposit, Camus et al., 1991; San Cristóbal deposit, Phillipson and Romberger, 2004; La Guitarra deposit, Camprubí et al., 2006; Caylloma district, Echavarría et al., 2006). The frequent presence of illite trapped within fluid inclusions in $\mathrm{Qz}_{1}$ (Fig. 13) indicates that pre-ore stage mineralization took place under slightly acidic conditions, because illite is formed at pH from 5.8 to 6.3 (Romberger, 1991) and temperatures from 220 to $300{ }^{\circ} \mathrm{C}$ (Henley and Ellis, 1983; Reyes, 1990), which are compatible with the obtained homogenization temperatures of the pre-ore stage fluid inclusions. $\mathrm{Py}_{1}$ and $\mathrm{Apy}_{1}$ are commonly zoned showing alternating As-rich and Sbrich bands, respectively. This may reflect slight compositional variations of the mineralizing solutions as an expression of disequilibrium and metastable conditions, as is commonly observed in epithermal deposits (e.g. Carrillo-Rosúa et al., 2008).

\subsubsection{Base-metal and Ag-bearing minerals stage}

The main mineralizing event observed in the Patricia deposit is deposition of two generations of sphalerite $\left(\mathrm{Sp}_{2 \mathrm{~A}}\right.$ and $\left.\mathrm{Sp}_{2 \mathrm{~B}}\right)$, galena $\left(\mathrm{Gn}_{2 \mathrm{~B}}\right)$ and minor amounts of pyrite, chalcopyrite, Ag-sulfosalts and trace of pyrrhotite within $\mathrm{Sp}_{2 \mathrm{~B}}$. Primary fluid inclusions studied in $\mathrm{Sp}_{2 \mathrm{~A}}$ and $\mathrm{Sp}_{2 \mathrm{~B}}$ indicate lower salinity $(2-10$ wt $\% \mathrm{NaCl})$ and lower homogenization temperatures than in the pre-ore stage. Stage 2 is characterized by a gradual cooling from 250 to $140^{\circ} \mathrm{C}$ at constant low to moderate salinity. Ag-bearing phases mainly occur at the end of this stage at temperatures ranging from 180 to $140^{\circ} \mathrm{C}$. The temperatures indicated by fluid inclusions for the substage $2 \mathrm{~B}$ are in agreement with those estimated using freibergite as geothermometer. This geothermometer is based on the isotherms calculated by Sack (2005) using the molar $\mathrm{Ag} /(\mathrm{Ag}+\mathrm{Cu})$ and $\mathrm{Zn} /(\mathrm{Zn}+\mathrm{Fe})$ ratio of freibergite (Fig. 14). The geothermometric analyses of freibergite, which is the most abundant Ag-bearing phase in the Patricia deposit, suggest that most of the silver mineralization took place in the interval from around 230 to less than $170{ }^{\circ} \mathrm{C}$, with most of the data plotting below the $170^{\circ} \mathrm{C}$ isotherm. Moreover, the occurrence of minor stephanite in the substage $2 \mathrm{~A}$ also marks another upper limit for $\mathrm{Ag}$ deposition at $197 \pm 5^{\circ} \mathrm{C}$ (e. g Keighin and Honea, 1969; Pallancata deposit, Gamarra-Urrunaga et al., 2013). Freibergite compositions giving temperatures above $200^{\circ} \mathrm{C}$ 
could represent re-equilibrated phases due to late higher temperature fluids that characterize the post-ore stage (Fig. 13) (see below). In addition, the data in Fig.14 support the existence of a miscibility gap in fahlores first predicted by O’Leary and Sack (1987) and confirmed by Sack et al. (2003) and Chutas and Sack (2004).

Precipitation of ore minerals due to decreasing temperature in hydrothermal systems is generally the result of either conductive loss of heat from the system or from mixing with a lower temperature fluid (Leach and Corbett, 2008). Cooling has also been described in some deposit as the main deposition process (e.g. San Cristobal deposit, Phillipson and Romberger, 2004) or as one of several mechanisms as boiling or fluid mixing (e.g. Faride deposit, Camus and Skewes, 1991; El Barqueño and La Guitarra deposits, Camprubí et al., 2006). Evidence in the Patricia deposit suggests that a combination of both mixing and cooling likely occurred. As stated earlier, a decrease in fluid salinity between stage 1 and stage 2 suggests possible dilution of an early brine due to mixing with a lower salinity fluid (e.g. Einaudi et al., 2003; Sillitoe and Hedenquist, 2003; Simmons et al., 2005). However, cooling seems to be the most important process responsible for the main stage of ore precipitation, as shown by fluid evolution during stage 2. The LA-ICP-MS data from fluid inclusions also show evidence of dilution because the $\mathrm{Na}, \mathrm{Ca}$ and $\mathrm{K}$ contents decrease from stage 1 to stage 2. In addition, the model proposed by Sack (2005) for Ag$\mathrm{Pb}-\mathrm{Zn}$ deposits, implying a primary high-temperature, high-Ag-galena phase that breaks down during cooling and gives rise to the silver mineralization, provides a reasonable reference for the Patricia deposit, which agrees with the cooling process recorded by fluid inclusions.

Sulfur and oxygen activities of the fluids during stage 2 have been estimated from the composition of sphalerite in equilibrium with pyrite according to Barton et al. (1977). The composition of $\mathrm{Sp}_{2 \mathrm{~A}}$ and $\mathrm{Sp}_{2 \mathrm{~B}}$ in equilibrium with pyrite ranges from 6 to $15 \mathrm{~mol} \% \mathrm{FeS}$ and plots within the sulfide dominant field in the sulfur vs. oxygen activity diagram (Fig. 15). Accordingly, sphalerite precipitated from a fluid with sulfur activity between -12.2 and -12.5 and oxygen activity around -38 . Additionally, the stability limits for Ag-bearing and $\mathrm{Pb}$-bearing minerals have been obtained of the sulfur activity $v s$ temperature diagram from Jasinski (1983).

8.2.3. Post-ore stage: 
The post-ore stage is defined by the deposition of quartz $\left(\mathrm{Qz}_{3}\right)$, pyrite $\left(\mathrm{Py}_{3}\right)$ and arsenopyrite $\left(\mathrm{Apy}_{3}\right)$, minor sphalerite and galena and the final precipitation of minor kutnohorite and trace amounts of Agbearing and $\mathrm{Pb}$-bearing minerals. Primary fluid inclusions studied within $\mathrm{Qz}_{3}$ indicate higher temperatures $\left(215-175^{\circ} \mathrm{C}\right)$ and similar salinity $(8-2 \mathrm{wt} \% \mathrm{NaCl})$ compared to the previous substage 2B (Fig. 13).

The rise in the temperature of the circulating fluids from stage $2 \mathrm{~B}$ to stage 3 could have been as much as 75 degrees Centigrade. This fact poses two important questions: 1) did fluid inclusions in sphalerite $\mathrm{Sp}_{2 \mathrm{~A}}$ and/or $\mathrm{Sph}_{2 \mathrm{~B}}$ re-equilibrate during the post-ore stage? and, therefore 2) are the obtained microthermometric data reliable? As pointed out by Bodnar and Bethke (1984), overheating of sphalerite may cause the fluid inclusions to stretch, leak or decrepitate, thus yielding incorrect microthermometric data. According to these authors, the amount of overheating necessary to initiate stretching in sphaleritehosted inclusions depends, among other factors, on the inclusion size and shape, and the confining pressure, ranging from $<8^{\circ} \mathrm{C}$ for inclusions several hundred $\mu \mathrm{m}$ in diameter to $>75^{\circ} \mathrm{C}$ for $10 \mu \mathrm{m}$-sized inclusions at 1 bar confining pressure. Fluid inclusion sizes in the Patricia sphalerites are usually below $10 \mu \mathrm{m}$, and only exceptionally reach $20 \mu \mathrm{m}$ (i.e. Fig. 12e). Regarding the confining pressure, fluid inclusion data presented in this paper belong to sphalerite from cores samples located at depths below present surface of 95 to $150 \mathrm{~m}$ (stage 2A) and 195 to $228 \mathrm{~m}$ (stage 2B) which, assuming hydrostatic pressure conditions as indicated by the veins open-space filling textures, correspond to minimum confining pressure around 10-15 bars and 20-23 bars, respectively. These cores were drilled in the uplifted eastern block of the deposit, which exposes a deeper part of the mineralization than the western blocks. This means that an unknown thickness of volcanic mineralized rocks has been already eroded and then, real confining pressures should be higher than the values estimated above (see below for further discussion on depth of ore deposition). According to Bodnar and Bethke (1984), the higher the confining pressure, the greater the amount of overheating required to initiate stretching for a given inclusion volume. Therefore, reequilibration of inclusions in sphalerite might have occurred due to the increase of temperature from stage $2 \mathrm{~A}$ to stage $2 \mathrm{~B}$, however the confining pressure was, most probably, high enough to prevent stretching, even in the shallower sphalerite samples ( $94 \mathrm{~m}$ below present surface, see below). 
Therefore, microthermometric data from sphalerite-hosted inclusions presented in this work are considered fully reliable.

In the post-ore stage, $\mathrm{Qz}_{3}, \mathrm{Py}_{3}$ and $\mathrm{Apy}_{3}$ commonly cement the brecciated sulfides of the main-ore stage, so the increase of temperature and similar salinity of the fluids in the post-ore stage were accompanied by brecciation and opening of spaces where the mineralization was ultimately deposited. These breccias indicate either a sharp pressure drop, maybe leading to limited boiling, or just a tectonic process. Boiling is not supported by fluid inclusion observations, and although the lack of fluid inclusion evidence for boiling does not preclude its occurrence, tectonic processes are likely to have occurred given the deposit active tectonic setting. However, according to Fig. 13, cooling is likely to be the main mechanism of mineral deposition in this stage.

The formation of zoned $\mathrm{Py}_{3}$ and $\mathrm{Apy}_{3}$ with As-rich and Sb-rich bands, respectively, in equilibrium with $\mathrm{Qz}_{3}$ suggests compositional variations in fluids similar to those observed in the pre-ore stage. During the final events of the post-ore stage and after precipitation of most sulfides, minor kutnahorite and Agbearing minerals such as freieslebenite and acanthite were precipitated. The presence in the late depositional stages of carbonates is a typical characteristic of the latest stages in epithermal deposits (Baumgartner et al., 2008; Canet et al., 2009; Catchpole et al., 2012; Sillitoe and Hedenquist, 2003) as a result of a last fluid pulse after the main mineralizing event. In other epithermal deposits, Ag-bearing minerals commonly precipitate during the last stages (e.g. Baumgartner et al., 2008; Bendezu and Fonboté, 2009; Camprubí et al., 2006; Gropper et al., 1991; Phillipson and Romberger, 2004; Vassileva et al., 2014) usually due to a combination of different factors involving mixing between magmatic and meteoric fluids, increasing oxygen fugacity and decreasing fluid temperature (Vassileva et al., 2014). Illite is also present as trapped crystals within fluid inclusions in $\mathrm{Qz}_{3}$. According to several authors (i.e Romberger, 1991; Moncada and Bodnar, 2012) the $\mathrm{pH}$ stability field for illite is around 6, whereas carbonates typically occur within neutral to alkaline conditions. The formation of kutnohorite is comparable to similar phases of $\mathrm{Ca} / \mathrm{Mn}$-bearing carbonates described in other epithermal ore deposits, whose deposition is favored by an increase of oxygen fugacity $\left(f \mathrm{O}_{2}\right)$ and $\mathrm{CO}_{2}$ concentration (e.g. Canet et al., 2009; Catchpole et al., 2012; Damian, 2003). Therefore, the formation of kutnohorite in the final 
post-ore stage suggests that slightly acidic-neutral fluids dominant during previous mineralization stages (from the pre-ore to post-ore stage), evolved at the end of the post-ore stage from neutral to alkaline fluids.

\subsection{Whole-ore composition}

Statistically significant and positive correlations between $\mathrm{Ag}-\mathrm{Cd}-\mathrm{Cu}-\mathrm{Pb}-\mathrm{Zn}$ and $\mathrm{Au}-\mathrm{As}-\mathrm{Ge}-\mathrm{Sb}-\mathrm{W}$ reflect the mineralogical control in the element distribution. The $\mathrm{Ag}-\mathrm{Cd}-\mathrm{Cu}-\mathrm{Pb}-\mathrm{Zn}$ group is related to base-metal sulfides (sphalerite, galena and chalcopyrite) and Ag-bearing minerals whereas the Au-As-Ge$\mathrm{Sb}-\mathrm{W}$ group is related to arsenopyrite and pyrite. The observed positive correlations between the Ag-Cd$\mathrm{Cu}-\mathrm{Pb}-\mathrm{Zn}$ group support the interpretation that these metals were preferentially deposited during the basemetal stage characterized by precipitation of sphalerite, galena, chalcopyrite and Ag-bearing minerals. The positive correlation between $\mathrm{Zn}$ and $\mathrm{Cd}\left(\mathrm{r}^{2}=0.99\right.$ and $\mathrm{p}$-value $\left.<0.001\right)$ is consistent with the fact that $\mathrm{Cd}$ substitutes for $\mathrm{Zn}$ in sphalerite, as reflected by the presence of trace amounts of $\mathrm{Cd}$ in sphalerite (up to $0.3 \mathrm{wt} \%)$. In contrast, the positive correlation between $\mathrm{Pb}$ and $\mathrm{Ag}\left(\mathrm{r}^{2}=0.97\right.$ and $\mathrm{p}$-value $\left.<0.001\right)$ is not related to the presence of $\mathrm{Ag}$ in galena because EPMA analyses of galena rarely show significant $\mathrm{Ag}$ content $(\sim 0.1$ wt $\%)$. Alternatively, the $\mathrm{Pb}-\mathrm{Ag}$ correlation in whole-ore composition can be explained by the fact of Ag-bearing minerals and galena are in close textural association with most of the Ag-bearing minerals occurring within galena. This occurrence is in agreement with the possible break down of highAg-galena into Ag-free galena and Ag-bearing phases during cooling (as proposed by Sack, 2005) that would further explain the observed $\mathrm{Pb}-\mathrm{Ag}$ correlation. The mean and standard deviation of the zinc/lead ratio (64.4 - 13.81, respectively) is in agreement with the predominance of sphalerite in the Patricia deposit.

The strong and positive Sb-As correlation $\left(\mathrm{r}^{2}=0.80\right.$ and $\mathrm{p}$-value $\left.<0.01\right)$, the wide distribution of these elements in the scatterplot (Fig.11) and their positive correlations in Py and Apy, all indicate that Sb and As substitute for each other in these minerals. Although Ag-sulfosalts also contain some $\mathrm{Sb}$, the lower relative proportion of these minerals in the whole-ore volume in comparison to arsenopyrite and pyrite probably led to the correlation of $\mathrm{Sb}$ with $\mathrm{Au}$ and As instead of Ag. The positive Au-As correlation $\left(r^{2}=0.94\right.$ and $p$-value $\left.<0,001\right)$, the low Au concentrations in all analyzed samples $(<1 \mathrm{ppm})$ and the 
absence of discrete Au-bearing minerals suggest that Au may be scarce (ppb or few ppm levels) within arsenopyrite and As-rich pyrite, but this cannot be proven until analysis are carried out on these minerals. The mineralogical control of Au by arsenopyrite or As-rich pyrite has been extensively documented previously (e.g. Huston and Large, 1989; Camus et al., 1991; Genkin et al., 1998; Hedenquist et al., 2000; Einaudi et al., 2003; John et al., 2003; Reich et al., 2005; Sung et al., 2009).

The presence of $\mathrm{Fe}$ in both arsenopyrite-pyrite and sphalerite-chalcopyrite explains the absence of statistically significant correlation of Fe with any other metal in the whole-ore composition. The absence of a statistically significant correlation of $\mathrm{Se}, \mathrm{Bi}, \mathrm{Te}, \mathrm{Co}$ and Mo with other metals also indicates the lack of mineralogical control for these metals within the paragenetic sequence established in the Patricia deposit.

\subsection{Depth of ore deposition and erosion of the eastern block}

Minimum depth of ore deposition below the paleowater table in the Patricia deposit can be estimated from hydrostatic boiling point curves (Haas, 1971) given that 1) hydrostatic pressure is indicated by openspace filling textures in the mineralized veins, and 2) there is no evidence for fluid boiling, at least in the pre-ore and main ore stages.

Microthermometric data, sampling depth and theoretical boiling depth (Haas, 1971) for some selected inclusions in $\mathrm{Qz}_{1}, \mathrm{Sp}_{2 \mathrm{~A}}$ y $\mathrm{Sp}_{2 \mathrm{~B}}$ are shown in Table 5. As indicated previously, fluid inclusions were studied in samples located between $95 \mathrm{~m}$ (lower limit of the oxidized zone) and $230 \mathrm{~m}$ deep (lower depth reached by drilling) in the deposit eastern block. Minimum depth of ore deposition estimated from boiling curves in this mineralized interval (Table 5) is only significant if it is equal or larger than the sampling depth below present surface (i.e. data from $\mathrm{Qz}_{1}$ and $\mathrm{Sp}_{2 \mathrm{~A}}$ ). Thus, ore deposition in the studied vertical section of the Patricia eastern block would have taken place, at least, from $210 \mathrm{~m}$ in the shallowest level below the oxidation blanket $\left(\mathrm{Sp}_{2 \mathrm{~A}}\right.$ at $94 \mathrm{~m}$ deep) to $320 \mathrm{~m}$ close to the deepest areas drilled to date $\left(\mathrm{Qz}_{1}\right.$ at $205 \mathrm{~m}$ deep). However, these values represent minimum depths as Ag-rich polymetallic epithermal mineralization usually occurs in relatively deep sections $(\sim 500 \mathrm{~m})$ of the epithermal environment (Hedenquist et al., 2000; Albinson et al., 2001; Camprubí and Albinson, 2006). 
The difference between theoretical boiling depths and sampling depth for each inclusion also provides an approximation to the minimum amount of erosion suffered by the uplifted eastern block of the Patricia deposit. The maximum difference obtained by this method (Table 5) indicates more than 200 m of volcano-sedimentary pile has been eroded. However, further geological evidence is needed to better constrain this value.

\subsection{Sulfidation state of the Patricia ore deposit}

The hydrothermal alteration, ore mineralogy and structural features of the Patricia vein system correspond to a $\mathrm{Zn}-\mathrm{Pb}-\mathrm{Ag}$ epithermal deposit mainly developed under intermediate-sulfidation (IS) conditions. The hydrothermal alteration characterized by illite \pm sericite \pm chlorite \pm quartz is typical of IS deposits (Einaudi et al., 2003). However. According to Einaudi et al. (2003), the absence of pyrrhotite in equilibrium with pyrite or arsenopyrite suggests that the first and last stages of the Patricia deposit took place under IS conditions, although maybe close to the limit with the LS field.

The paragenetic sequence of the main ore stage consists of sphalerite, galena, chalcopyrite, pyrrhotite and Ag-bearing minerals. The sphalerite, galena and chalcopyrite deposition is usually related to IS conditions and it has been commonly described in some epithermal deposits. (e.g. Hedenquist et al., 2000; Einaudi et al., 2003; Sillitoe and Hedenquist, 2003; Camprubí and Albinson, 2006; Carillo-Rosúa et al., 2008; Bendezu and Fonboté, 2009). Moreover, the composition of the sphalerite ranges from 6 to 15 mol.\% FeS, which is consistent with sphalerite compositions from IS systems that range from $<1$ to 10 mol.\% FeS and locally up to 20 mol.\% FeS (Hedenquist et al., 2000; Einaudi et al., 2003; Simmons et al., 2005). The Ag:Au ratio of the whole-ore composition in the Patricia deposit ranges from 200 to 6000 , values in accordance with IS systems where the Ag:Au ratio is always higher than 100 (Einaudi et al., 2003).

On the basis of stability fields of common sulfide species in $\mathrm{T}-f \mathrm{~S}_{2}$ space, Einaudi et al. (2003) characterized the mineralogy of very low, low, middle, high and very high sulfidation systems. Accordingly, the whole paragenetic sequence observed in the Patricia ore deposit belongs to the intermediate sulfidation type within the stability field of chalcopyrite and pyrite (Fig. 16). Fluids of the pre-ore stage plot in an area on the $\mathrm{T}-f \mathrm{~S}_{2}$ space characterized by moderate sulfur fugacity during pyrite 
and arsenopyrite deposition. During the main-ore stage, fluids progressed to lower sulfur fugacities and cooler conditions favoring the precipitation of sphalerite, galena and chalcopyrite, as well as Ag-bearing minerals. Finally, during the post-ore stage, fluids plot are higher sulfur fugacity and temperature, similar to those of the pre-ore stage, supporting the deposition of additional arsenopyrite and pyrite. The formation of kutnohorite and Ag-bearing minerals during the final post-ore stage indicates progressive cooling with an increase of $\mathrm{pH}$ and oxygen fugacity. Therefore, the suggested evolution for the Patricia deposit implies the existence of different pulses of fluids and fracturing supported by open-space filling and brecciation textures observed in the mineralized veins.

\section{Concluding remarks}

The Patricia $\mathrm{Zn}-\mathrm{Pb}-\mathrm{Ag}$ ore deposit is an intermediate sulfidation hydrothermal system associated with Cordilleran volcanism (i.e. Camprubí and Albinson, 2006). The localization of the ore bodies is controlled by extensional structures developed during the regional dominant sinistral strike-slip movement along the Domeyko fault system, at the northern extent of which the Patricia deposit is located. This overall sinistral transpressive regime created local transtensive domains with development of open spaces for hydrothermal ore deposition.

The mineralizing system was characterized by reduced fluids with $\mathrm{pH}$ close to neutral conditions that evolved from an initial stage characterized by saline fluids $(6-22 \mathrm{wt} \% \mathrm{NaCl})$ with a minimum circulation temperature of $205^{\circ} \mathrm{C}$, likely reflecting the mixing between brine a more dilute fluid. This was followed by the main mineralization event that precipitated base metals- and Ag-bearing minerals, from a low to moderate salinity $\left(1-9\right.$ wt $\% \mathrm{NaCl}$ ) fluid that progressively cooled from $\sim 250^{\circ} \mathrm{C}$ to $\sim 140^{\circ} \mathrm{C}$. The late stage is characterized by a fluid temperature increase to $\sim 215^{\circ} \mathrm{C}$ and subsequent cooling to $175^{\circ} \mathrm{C}$ with no salinity variation.

The Patricia deposit is presently divided into two blocks by a set of NNW-ESE-trending reverse faults, which uplifted the eastern block and exhumed thicker and deeper parts of the deposit that exhibit IS features. At least $200 \mathrm{~m}$ of the host volcano-sedimentary pile have been eroded from this block. In 
contrast, the western block exposes a shallower part of the system where cherts, amorphous silica and jasperoids, typical of thermal spring settings, occur. So far, exploration activity has focused in the eastern part of the deposit, and little attention has been paid to the western areas as early drilling intersected veinlets with little interesting mineralization. However, the structural framework defined in this paper strongly suggests that surficial thermal spring showings in the western block could likely progress to lowsulfidation conditions at shallow depths followed by a gradual variation towards a polymetallic intermediate-sulfidation ore system at depth, equivalent to the one observed in the eastern block. Furthermore, the eastern part of the deposit most probably has an extension of the mineralized veins both at depth, as drilling has not reached the lower limit of mineralization, and towards the south beyond the ignimbrite unit, as stockwork and silicification were observed in that area during the mapping campaign included in the present work. Therefore, we propose that the Patricia ore deposit can be significantly larger than the reserves estimated at present and hidden resources are still to be discovered.

\section{Acknowledgement}

This work was made possible by Herencia Resources Plc., which provided access to drill core and geologic information. Appreciation is expressed to the technical staff of Herencia Resources Plc. at the Patricia deposit, for their assistance during our studies of the deposit. A warm memory is especially devoted to Antonio Valverde, chief geologist at Paguanta project and co-author of this paper, who recently passed away. We would like to thank A. Larios and X. Llovet from the Centro Nacional de Microscopía Electrónica in the Complutense University of Madrid and from the Serveis Cientifico-tècnics of the Universitat of Barcelona, respectively, for their assistance with the electron microprobe in the chemical analyses of the minerals. We also thank B. Soutullo for their assistance with XRD from the Cristalografía y Mineralogía department in the Complutense University of Madrid. We would like to thank Dr. L. Fedele for their technical support with LA-ICP-MS analysis. This research was financially supported by the project CGL2010 - 17668 (Ministerio de Economía y Competitividad of Spain) and the company Herencia Resources Plc. Finally, we thank Franco Pirajno, editor of OGR, and two anonymous reviewers whose comments and suggestions have largely contributed to improve the paper. 


\section{References}

Albinson, T., Norman, D.I., Cole, D., Chomiak, B., 2001. Controls on formation of low-sulfidation epithermal deposits in Mexico: Constraints from fluid inclusion and stable isotope data. Society of Economic Geologists, Special Publication, 8, pp, 1-32.

Allmendinger, R.W., Smalley, R.Jr., Bevis, M., Caprio, H., Brooks, B., 2005. Bending the Bolivian orocline in real time. Geology 33, 905-908. http://dx.doi.org/ 10.1130/G21779.1

Arriagada, C., Roperch, P., Mpodozis, C., Cobbold, P., 2008. Paleogene building of the Bolivian Orocline: tectonic restoration of the central Andes in 2-D map view. Tectonics 27, TC6014. http://dx.doi.org/10.1029/2008TC002269.

Barton, Jr., Bethke, P.M., Roedder, E., 1977. Environment of ore deposition in the Creede Mining District, San Juan Mountains Colorado: Part III. Progress toward interpretation of the chemistry of the ore-forming fluid for the $\mathrm{OH}$ Vein. Econ. Geol. 72, 1-24. http://dx.doi.org/10.2113/gsecongeo.72.1.1

Baumgartner, R., Fonboté, L., Vennemann, T., 2008. Mineral zoning and geochemistry of epithermal polymetallic Zn-Pb-Ag-Cu-Bi mineralization at Cerro de Pasco, Peru. Econ. Geol. 103, 493-537. http://dx.doi.org/10.2113/gsecongeo.103.3.493

Behn, G., Camus, F., Carrasco, P., 2001. Aeromagnetic signature of porphyry copper systems in northern Chile and its geologic implications. Econ. Geol. 96, 239-248. http://dx.doi.org/10.2113/gsecongeo.96.2.239

Bendezu, R., Fonboté, L., 2009. Cordilleran epithermal Cu-Zn-Pb (Au-Ag) mineralization in the Colquijirca District, Central Peru: deposit-scale mineralogical patterns. Econ. Geol. 104, 905-944. http://dx.doi.org/10.2113/econgeo.104.7.905

Bodnar, R.J., Bethke, P.M., 1984. Systematics of stretching of fluid inclusions; I, Fluorite and sphalerite at 1 atmosphere confining pressure. Econ. Geol. 79, 141-161. http://dx.doi.org/10.2113/gsecongeo.79.1.141 
Bodnar, R.J., 1993. Revised equation and table for determining the freezing point depression of $\mathrm{H}_{2} \mathrm{O}-$ $\mathrm{NaCl}$ solutions. Geochim. Cosmochim. Acta. 57, 683-684. http://dx.doi.org/10.1016/00167037(93)90378-A

Bodnar, R.J., 2003. Introduction to aqueous-electrolyte fluid inclusions. In: Fluid inclusions: Analysis and Interpretation, 32 (Eds.) I. Samson, A. Anderson and D. Marshall). Mineral. Assoc. Canada, pp, 8189, Short Course.

Bouzari, F., Clark, A.H., 2002. Anatomy, evolution and metallogenic significance of the supergene ore body of the Cerro Colorado porphyry copper deposit, I Region, northern Chile. Econ. Geol. 97, 1701-1740. http://dx.doi.org/10.2113/gsecongeo.97.8.1701

Campbell, I.H., Ballard, J., Palin, J.M., Allen, C., Faunes, A., 2006. U-Pb zircon geochronology of granitic rocks from the Chuquicamata-El Abra porphyry copper belt of northern Chile: excimer laser ablation ICP-MS analysis: Econ. Geol. 1327-1344. http://dx.doi.org/10.2113/gsecongeo.101.7.1327

Camprubí, A., Chomiak, B.A., Villanueva-Estrada, R.E., Canals, À., Norman, D.I., Cardellach, E., Stute, M., 2006. Fluid sources for the La Guitarra epithermal deposit (Temascaltepec district, Mexico): Volatile and helium isotope analyses in fluid inclusions. Chem. Geol. 231(3), 252-284. http://dx.doi.org/10.1016/j.chemgeo.2006.02.002

Camprubí, A., González-Partida, E., Iriondo, A., Levresse, G., 2006. Mineralogy, fluid characteristics, and depositional environment of the Paleocene epithermal Au-Ag deposits of the El Barqueño District, Jalisco, Mexico. Econ. Geol. 101, 235-247. http://dx.doi.org/ 10.2113/gsecongeo.101.1.235

Camprubí, A., Albinson, T., 2006. Depósitos epitermales en México: actualización de su conocimiento y reclasificación empírica. B. Soc. Geol. Mex. 1, 27-81.

Camus, F., Boric, R., Skewes, M.A., Castelli, J.C., Reichhard, E., Mestre, A., 1991. Geologic, structural, and fluid inclusion studies of El Bronce epithermal vein system, Petorca, central Chile. Econ. Geol. 86, 1317-1345. http://dx.doi.org/10.2113/gsecongeo.86.6.1317

Camus, F., Dilles, J.H., 2001. A special issue devoted to porphyry copper deposits of northern Chile. Econ. Geol. 96(2), 233-238. http://dx.doi.org/10.2113/gsecongeo.96.2.233 
Camus, F., Skewes, M.A., 1991. The Faride epithermal silver-gold deposit, Antofagasta region, Chile. Econ. Geol. 86, 1222-1237. http://dx.doi.org/ 10.2113/gsecongeo.86.6.1222

Canet, C., Camprubí, A., González-Partida, E., Linares, C., Alfonso, P., Piñeiro-Fernández, F., ProlLedesma, R.M., 2009. Mineral assemblages of the Francisco I. Madero $\mathrm{Zn}-\mathrm{Cu}-\mathrm{Pb}-(\mathrm{Ag})$ deposit, Zacatecas, Mexico: Implications for ore deposit genesis. Ore Geol. Rev. 35, 423-435. http://dx.doi.org/10.1016/j.oregeorev.2009.02.004

Capitanio, F., Faccenna, C., Zlotnik, S., Stegman, D., 2011. Subduction dynamics and the origin of Andean orogeny and the Bolivian orocline, Nature 480, 83-86. http://dx.doi.org/10.1038/nature10596

Catchpole, H., Kouzmanov, K., Fonboté, L., 2012. Copper-Excess stannoidite and tennantite-tetrahedrite as proxies for hydrothermal fluid evolution in a zoned cordilleran base metal district, Morococha, Central Peru. Can. Mineral. 50, 719-743. http://dx.doi.org/10.3749/canmin.50.3.719

Carrillo-Rosúa, J., Morales-Ruano, S., Morata, D., Boyce, A.J., Belmar, M., Fallick, A.E., Fenoll HachAli, P., 2008. Mineralogy and geochemistry of El Dorado epithermal gold deposit, El Sauce district, central-northern Chile. Mineral. Petrol. 92, 341-360. http://dx.doi.org/10.1007/s00710-007-0203-7

Chauvet, A., Bailly, L., André, A.S., Monié, P., Cassard, D., Tajada, F.L., Tuduri, J., 2006. Internal vein texture and vein evolution of the epithermal Shila-Paula district, southern Peru. Miner. Deposita 41, 387-410. http://dx.doi.org/10.1007/s00126-006-0068-4

Chutas, N.I., Sack, R.O., 2004. Ore genesis at La Colorada Ag-Zn-Pb deposit in Zacatecas, Mexico. Mineral Mag, 68, pp, 923-937. http://dx.doi.org/10.1180/0026461046860231

Coira, B., Davidson, J., Mpodozis, C., Ramos, V., 1982. Tectonic and magmatic evolution of the Andes of northern Argentina and Chile. Earth Sci. Rev. 18, 303-332. http://dx.doi.org/10.1016/0012$8252(82) 90042-3$

Cotton, W.B., 2003. Near infrared and XRD quantification of porphyry copper alteration at Cerro Colorado and Spence, Chile. (Doctoral dissertation, $\mathrm{PhD}$ thesis, University of Colorado, Boulder, USA. 
Echavarria, L., Nelson, E., Humphrey, J., Chávez, J., Escobedo, L., Iriondo, A., 2006. Geologic evolution of the Caylloma epithermal vein district, southern Perú. Econ. Geol. 101, 843-863. http://dx.doi.org/10.2113/gsecongeo.101.4.843

Einaudi, M.T., Hedenquist, J.W., Inan, E.E., 2003. Sulfidation state of hydrothermal fluids: the porphyryepithermal transition and beyond. In: Simmons, S.F., Graham, I.J. (Eds.), Volcanic, Geothermal and Ore-forming Fluids: Rulers and Witnesses of Processes Within the Earth. Society of Economic Geologists and Geochemical Society Special Publication, 10, pp. 285-313.

Damian, G., 2003. The genesis of the base metal ore deposit from Herja. Studia UBB, Geologia, 48(1), 85-100.

Davidson, J., Mpodozis, C., 1991. Regional Geologic Setting of Epithermal Gold Deposits, Chile. Econ. Geol. 86, 1174-1186. http://dx.doi.org/10.2113/gsecongeo.86.6.1174

Dilles, J.H., Tomlinson, A.J., Martín, M.W., Blanco, N., 1997. El Abra and Fortuna Complexes: a porphyry copper batholith sinistrally displaced by the Falla Oeste. In Congreso Geológico Chileno, 8th Actas, 3, pp. 1883-1887.

Farías, M., Charrier, R., Comte, D., Martinod, J., Hérail, G., 2005. Late Cenozoic deformation and uplift of the western flank of the Altiplano: Evidence from the depositional, tectonic, and geomorphologic evolution and shallow seismic activity (northern Chile at $19^{\circ} 30^{\prime} \mathrm{S}$ ), Tectonics 24 , TC4001. http://dx.doi.org/10.1029/2004TC001667.

Galli, C., 1957. Las formaciones geológicas en el borde occidental de la puna de Atacama, sector de Pica, Tarapacá. Minerales 56, 14-26.

Galli, C., 1968. Carta Geológica de Chile: Cuadrángulo Juan de Morales, Provincia de Tarapacá, Escala 1:50,000: Instituto de Investigaciones Geológicas de Chile, Carta 18, 53 p.

Galli, C., Dingman, I., 1962. Cuadrángulos Pica, Alca, Matilla y Chacarilla, con un estudio sobre los recursos de agua subterránea. Provincia de Tarapacá. Instituto de Investigaciones Geológicas, Carta Geológica de Chile, 3(2), 3. 
Gamarra-Urrunaga, J.E., Castroviejo, R., Bernhardt, H.J., 2013. Preliminary mineralogy and ore petrology of the intermediate-sulfidation Pallancata deposit, Ayacucho, Peru. Can. Mineral. 51, 6791. http://dx.doi.org/10.3749/canmin.51.1.67

García, M., Hérail, G., 2001. Comment on Geochronology (Ar-Ar, K-Ar and He-exposure ages) of Cenozoic magmatic rocks from northern Chile $\left(18-22^{\circ} \mathrm{S}\right)$ : implications for magmatism and tectonic evolution of the central Andes of Wörner et al. 2000. Revista Geológica de Chile 28, 127-130. http://dx.doi.org/10.4067/S0716-02082001000100008

Genkin, A.D., Bortnikov, N., Cabri, L.J., Wagner, F.E., Stanley, C.J., Safonov, Y.G., McMahon, G., Friedl, J., Kerzin, A.L., Gamyanin, G.N., 1998. A multidisciplinary study of invisible gold in arsenopyrite from four mesothermal gold deposits in Siberia, Russian Federation. Econ. Geol. 93, 463-487. http://dx.doi.org/10.2113/gsecongeo.93.4.463

Goldstein, R.H., Reynolds, T.J., 1994. Systematics of fluid inclusions in diagenetic minerals: Society of Economic Geologists and Paleontologists. Short Course 31, 199.

Gröpper, H., Calvo, M., Crespo, H., Bisso, C.R., Cuadra, W.A., Dunkerley, P.M., Aguirre, E. 1991. The epithermal gold-silver deposit of Choquelimpie, Northern Chile. Econ. Geol. 86, 1206-1221. http://dx.doi.org/10.2113/gsecongeo.86.6.1206

Haas, J.L., 1971. The effect of salinity on the maximum thermal gradient of a hydrothermal system at hydrostatic pressure. Econ. Geol. 66, 940-946. http://dx.doi.org/10.2113/gsecongeo.66.6.940

Harambour, S., 1990. Geología pre-Cenozoica de la Cordillera de los Andes entre las quebradas Aroma y Juan de Morales. PhD Thesis, Departamento de Geología, Universidad de Chile, Santiago.

Hedenquist, J.W., Arribas, A.Jr., Urien-González, E., 2000. Exploration for epithermal gold deposits. Rev. Econ. Geol 13, 245-277.

Henley, R.W., Ellis, A.J., 1983. Geothermal systems ancient and modern: a geochemical review. EarthSci Rev. 19, 1-50. http://dx.doi.org/10.1016/0012-8252(83)90075-2

Huston, D.L., Large, R.R., 1987. Genetic and exploration significance of the zinc ratio (100 Zn/ ( $\mathrm{Zn}+$ $\mathrm{Pb})$ in massive sulfide systems. Econ. Geol. 82, 1521-1539. http://dx.doi.org/10.2113/gsecongeo.82.6.1521 
Huston, D.L., Large, R.R., 1989. A chemical model for the concentration of gold in volcanogenic massive sulphide deposits. Ore Geol. Rev. 4, 171-200. http://dx.doi.org/10.1016/0169-1368(89)90017-6

Huston, D.L., Stevens, B., Southgate, P.N., Muhling, P., Wyborn, L., 2006. Australian Zn-Pb-Ag oreforming systems: a review and analysis. Econ. Geol. 101, 1117-1157. http://dx.doi.org/10.2113/gsecongeo.101.6.1117

Isacks, B.L., 1988. Uplift of the central Andean plateau and bending of the Bolivian orocline. J. Geophys. Res. 93, 3211-3231. http://dx.doi.org/10.1029/JB093iB04p03211

Jarosewich, E., Nelen, J.A., Norberg, J.A., 1980. Reference samples for electron microprobe analysis. Geostandars Newsletter 4, 43-47. http://dx.doi.org/10.1111/j.1751-908X.1980.tb00273.x

Jasinski, A.W., 1983. Some aspects of the silver mineralization in the Hfillefors region (Bergslagen, Sweden). Mineral. Mag. 47, 507-14.

John, D.A., Hofstra, A.H., Fleck, R.J., Brummer, J.E., Saderholm, E.C., 2003. Geologic setting and genesis of the Mule Canyon low-sulfidation epithermal gold-silver deposit, north-central Nevada. Econ. Geol. 98, 425-463. http://dx.doi.org/10.2113/gsecongeo.98.2.425

Keighin, C.W., Honea, R.M., 1969. The system Ag-Sb-S from $600{ }^{\circ} \mathrm{C}$ to $200{ }^{\circ} \mathrm{C}$. Miner. Deposita 4 , $153-$ 171. http://dx.doi.org/10.1007/BF00208050

Leach, T., Corbett, G., 2008. Fluid mixing as a mechanism for bonanza grade epithermal gold formation. In Paper presented at the Terry Leach Symposium, 17. http://dx.doi.org/10.13140/2.1.2429.1847

Maksaev, V., 1990. Metallogenic, geological evolution and thermochronology of the Chilean Andes between latitudes $21^{\circ}$ and $26^{\circ} \mathrm{S}$, and the origin of major porphyry copper deposits. PhD Thesis, Dalhousie University, Canada.

Maksaev, V., Townley, B., Palacios, C., Camus, F., 2007. Metallic ore deposits. In: Moreno T, Gibbons W. (ed) The Geology of Chile. The Geological Society of London, pp, 179-199.

Maksaev, V., Zentilli, M., 1999. Fission track thermochronology of the Domeyko Cordillera, northern Chile; implications for Andean tectonics and porphyry copper metallogenesis: Exploration and Mining Geology, 8, 65-89. 
Maronna, R.A., Martin, D.R., Yohai, V.J., 2006. Robust Statistics; Theory and Methods. Ed. Wiley. 87171.

McGuire, A.V., Francis, C.A., Dyar, M.D. 1992. Mineral standards for electron microprobe analysis of oxygen. Am. Mineral 77, 1087-1091.

Moncada, D., Bodnar, R.J., 2012. Gangue mineral textures and fluid inclusion characteristics of the Santa Margarita Vein in the Guanajuato Mining District, Mexico. Cent. Eur. J. Geosci, 4, 300-309. http://dx.doi.org/10.2478/s13533-011-0057-8

Moore, D.M., Reynolds, R.C., 1989. X-ray diffraction and the identification and analysis of clay minerals. Vol. 378. Oxford: Oxford university press.

Mpodozis, C., Ramos, V., 1990. The Andes of Chile and Argentina. In: G. Eriksen et al. (Eds.), Geology of the Central Andes and its relation to Hydrocarbon and Mineral Resources. Circum-Pacific Council for Energy and Mineral Resources, Houston, TX. Earth. Sci. Ser. 11, 59-90.

Noble, D.C., McKee, E.H., Mégard, F., 1979. Early Tertiary "Incaic” tectonism, uplift, and volcanic activity, Andes of central Peru: Geol. Soc. Am. Bull, 90, 903-907. http://dx.doi.org/10.1130/00167606(1979)90<903:ETITUA>2.0.CO;2

O'Leary, M.J., Sack, R.O., 1987. Fe-Zn exchange reaction between tetrahedrite and sphalerite in natural environments. Contrib Mineral Petr, 96, pp, 415-425. http://dx.doi.org/10.1007/BF01166687

Pacci, D., Cáceres, R., Sayes, J., Monti, S. 1980. Inventario de yacimientos metálicos y no-metálicos. I Región de Tarapacá. Tomo I-V, Antecedentes geológicos y mineros básicos. Instituto de Investigaciones Geológicas.

Phillipson, S.E., Romberger, S.B., 2004. Volcanic stratigraphy, structural controls, and mineralization in the San cristobal Ag-Zn-Pb deposit, southern Bolivia. J. S. Am. Earth. Sci. 16, 667-683. http://dx.doi.org/10.1016/j.jsames.2003.11.002

Pinto, L., Hérail, G., Charrier, R., 2004. Sedimentación sintectónica asociada a las estructuras neógenas en la Precordillera de la zona de Moquella, Tarapacá (19²15'S, norte de Chile). Revista Geológica de Chile 31, 19-44. http://dx.doi.org/10.4067/S0716-02082004000100002 
Reich, M., Kesler, S.E., Utsunomiya, S., Palenik, C.S., Chryssoulis, S.L., Ewing, R.C., 2005. Solubility of gold in arsenian pyrite. Geochim. Cosmochim. Acta. 69, 2781-2796. http://dx.doi.org/10.1016/j.gca.2005.01.011

Reyes, A.G., 1990. Petrology of Philippine geothermal systems and the application of alteration mineralogy to their assessment. J. Volcanol. Geoth. Res. 43, 279-309. http://dx.doi.org/10.1016/0377-0273(90)90057-M

Roel, J., Ortega, L., Piña, R., Lunar, R., 2013. Estudio preliminar de la mineralización de Cu-Ag de Doris, Proyecto minero Paguanta, NE Chile. MSc Thesis. Complutense University of Madrid.

Romberger, S.B., 1991. Transport and deposition of precious metals in epithermal deposits. In: Raines, G.L., Lisle, R.E., Schafer, R.W., Wilkinson, W.H. (Eds.), Geology and Ore Deposits of the Great Basin Symposium Proceedings, Geological Society of Nevada, Reno, pp, 219-232.

Sack, R.O., 2005. Internally consistent database for sulfides and sulfosalts in the system Ag2S-Cu2SZnS-FeS-Sb2S3-As2S3. Geochim. Cosmochim. Acta. 69, 1157-1164. http://dx.doi.org/10.1016/S0016-7037(00)00468-3

Sack, R. O., Lichtner, P.C., 2009. Constraining compositions of hydrothermal fluids in equilibrium with polymetallic ore-forming sulfide assemblages. Econ Geol, 104, 1249-1264. http://dx.doi.org/10.2113/gsecongeo.104.8.1249

Sayes, J., 1978. Cuadrángulos Collacagua y Laguna del Huasco, Provincia de Iquique, I Región: escala 1:100.000. Instituto de Investigaciones Geológicas de Chile, pp, 43.

Seedorff, E., Dilles, J.H., Proffett, J.M., Einaudi, M.T., Zurcher, L., Stavast, W.J.A., Barton, M.D., 2005. Porphyry deposits: characteristics and origin of hypogene features. Econ Geol. 100th Anniversary Volume, 29, pp, 251-298.

Scheuber, E., Reutter, K., 1992. Magmatic arc tectonics in the Central Andes between $21^{\circ}$ and $25^{\circ} \mathrm{S}$, Tectonophysics 25, 127-140. http://dx.doi.org/10.1016/0040-1951(92)90422-3

Schlunegger, F., Kober, F., Zeilinger, G., von Rotz, R., 2010. Sedimentology-based reconstructions of paleoclimate changes in the Central Andes in response to the uplift of the Andes, Arica region 
between 19 and $21^{\circ} \mathrm{S}$ latitude, northern Chile. Int. J. Earth Sci. 99, 123-137. http://dx.doi.org/10.1007/s00531-010-0572-8

Shamanian, G.H., Hedenquist, J.W., Hattori, K.H., Hassanzadeh, J., 2004. The Gandy and Abolhassani epithermal prospects in the Alborz magmatic arc, Semnan province, Northern Iran. Econ. Geol. 99, 691-712. http://dx.doi.org/10.2113/gsecongeo.99.4.691

Sillitoe, R.H., 1981. Regional aspects of the Andean porphyry copper belt in Chile and Argentina: Transactions of the Institute of Mining and Metallurgy, 90, B15-B36.

Sillitoe, R.H., Hedenquist, J.W., 2003. Linkages between volcanotectonic settings, ore-fluid compositions, and epithermal precious metal deposits. In: Simmons, S.F., Graham, I. (Eds.), Volcanic, Geothermal, and Ore-forming Fluids: Rulers and Witnesses of Processes Within the Earth. Society of Economic Geologists, Special Publication, Society of Economic Geologists. Special Publication, 10, pp. 315-343.

Sillitoe, R.H., Perelló, J., 2005. Andean copper province: tectonomagmatic settings, deposit types, metallogeny, exploration, and discovery: Econ. Geol. 100th Anniversary volume, pp, 845-890.

Sillitoe, R.H., 2010. Porphyry copper systems. Econ Geol, 105, pp, 3-41. http://dx.doi.org/10.2113/gsecongeo.105.1.3

Simmons, S., White, N., John, D.A., 2005. Geological characteristics of epithermal precious and base metal deposits. In: Hedenquist, J.W., Thompson, J.F.H., Goldfarb, R.J., Richards, J,P., (Eds.), 100th anniversary volume, 1905-2005. Econ Geol. pp, 485-522

Sinclair, W.D., Kooiman, G.J.A., Martin, D.A., Kjarsgaard, I.M., 2006. Geology, geochemistry and mineralogy of indium resources at Mount Pleasant, New Brunswick, Canada. Ore Geol. Rev. 28, 123-145. http://dx.doi.org/10.1016/j.oregeorev.2003.03.001

Sterner, S.M., Bodnar, R.J., 1984. Synthetic fluid inclusions in natural quartz I. Compositional types synthesized and applications to experimental geochemistry. Geochim. Cosmochim. Acta, 48, 26592668. http://dx.doi.org/10.1016/0016-7037(84)90314-4

Sung, Y.H., Brugger, J., Ciobanu, C.L., Pring, A., Skinner, W., Nugus, M., 2009. Invisible gold in arsenian pyrite and arsenopyrite from a multistage Archaean gold deposit: Sunrise Dam, Eastern 
Goldfields Province, Western Australia. Miner. Deposita 44, 765-791. http://dx.doi.org/10.1007/s00126-009-0244-4

Thomas, N.A., 1967. Carta geológica de Chile: Cuadrángulo Mamiña, Provincia de Tarapacá: Instituto de Investigaciones Geológicas de Chile, carta 17, escala 1:50,000, pp, 49.

Tomlinson, A.J., Blanco, N., 1997a. Structural evolution and displacement history of the West Fault System, Precordillera, Chile: part 1, synmineral history: Congreso Geológico Chileno VIII, Antafogasta, Chile, pp. 1873-1877.

Tomlinson, A.J., Blanco, N., 1997b. Structural evolution and displacement history of the West Fault System, Precordillera, Chile: part 2, postmineral history: Congreso Geológico Chileno VIII, Antafogasta, Chile, pp. 1878-1882.

Tomlinson, A.J., Blanco, N., Maksaev, V., Dilles, J.H., Grunder, A., Ladino, M., 2001. Geología de la Precordillera Andina de Quebrada Blanca-Chuquicamata, Regiones I y II $\left(20^{\circ} 30^{\prime}-22^{\circ} 30^{\prime} \mathrm{S}\right)$. Servicio Nacional de Geología y Minería (SERNAGEOMIN), Santiago, Chile, Informe Registrado IR-01-20, 20.

Vassileva, R.D., Atanassova, R., Kouzmanov, K., 2014. Tennantite-tetrahedrite series from the Madan $\mathrm{Pb}-\mathrm{Zn}$ deposits, Central Rhodopes, Bulgaria. Miner. Petrol. 108, 515-531. http://dx.doi.org/10.1007/s00710-013-0316-0

Victor, P., Oncken, O., Glodny, J., 2004. Uplift of the western Altiplano plateau: Evidence from the Precordillera between $20^{\circ}$ and $21^{\circ} \mathrm{S}$ (northern Chile). Tectonics 23, 4. http://dx.doi.org/10.1029/2003TC00151

White, N.C., Hedenquist, J.W., 1995. Epithermal gold deposits: styles, characteristics and exploration. SEG newsletter, 23, pp, 9-13.

Wörner, G., Seyfried, H., 2001. Reply to the Comment by M. García and G. Hérail on 'Geochronology (Ar-Ar, K-Ar and He-exposure ages) of Cenozoic magmatic rocks from northern Chile $\left(18-22^{\circ} \mathrm{S}\right)$ : implications for magmatism and tectonic evolution of the central Andes' by Wörner et al. (2000). Revista Geológica de Chile 28: 131-137. http://dx.doi.org/10.4067/S0716-02082001000100009 


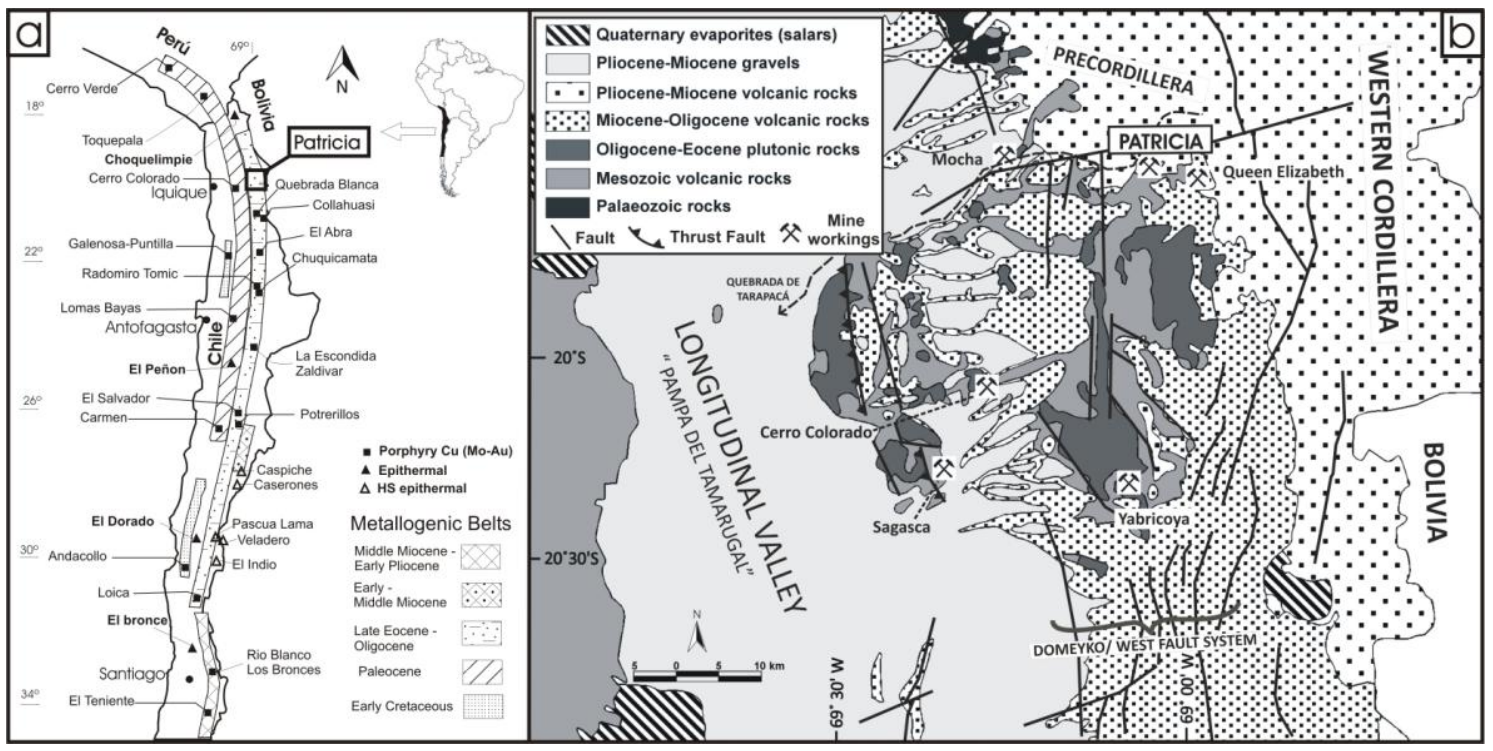

Figure 1 

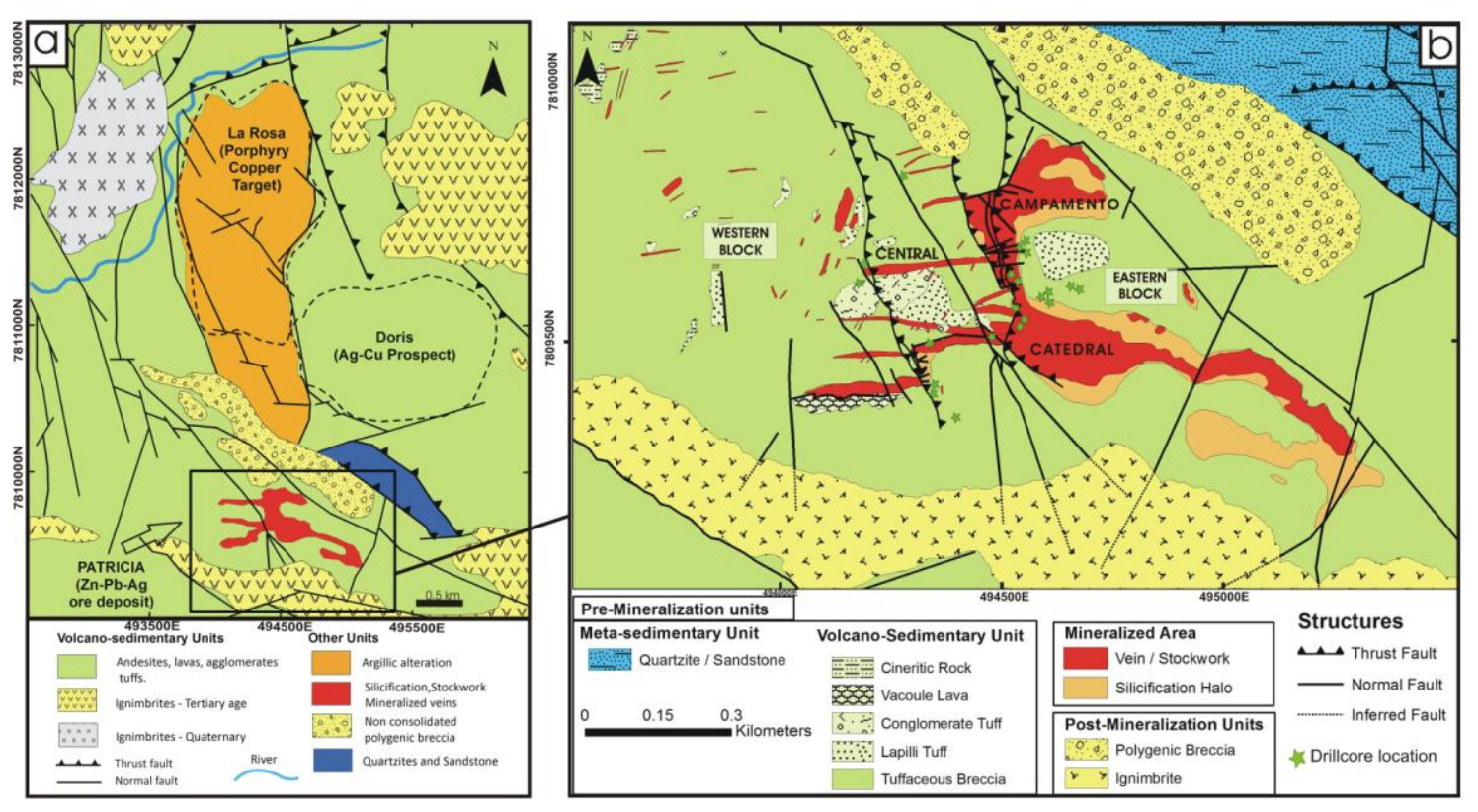

Figure 2 

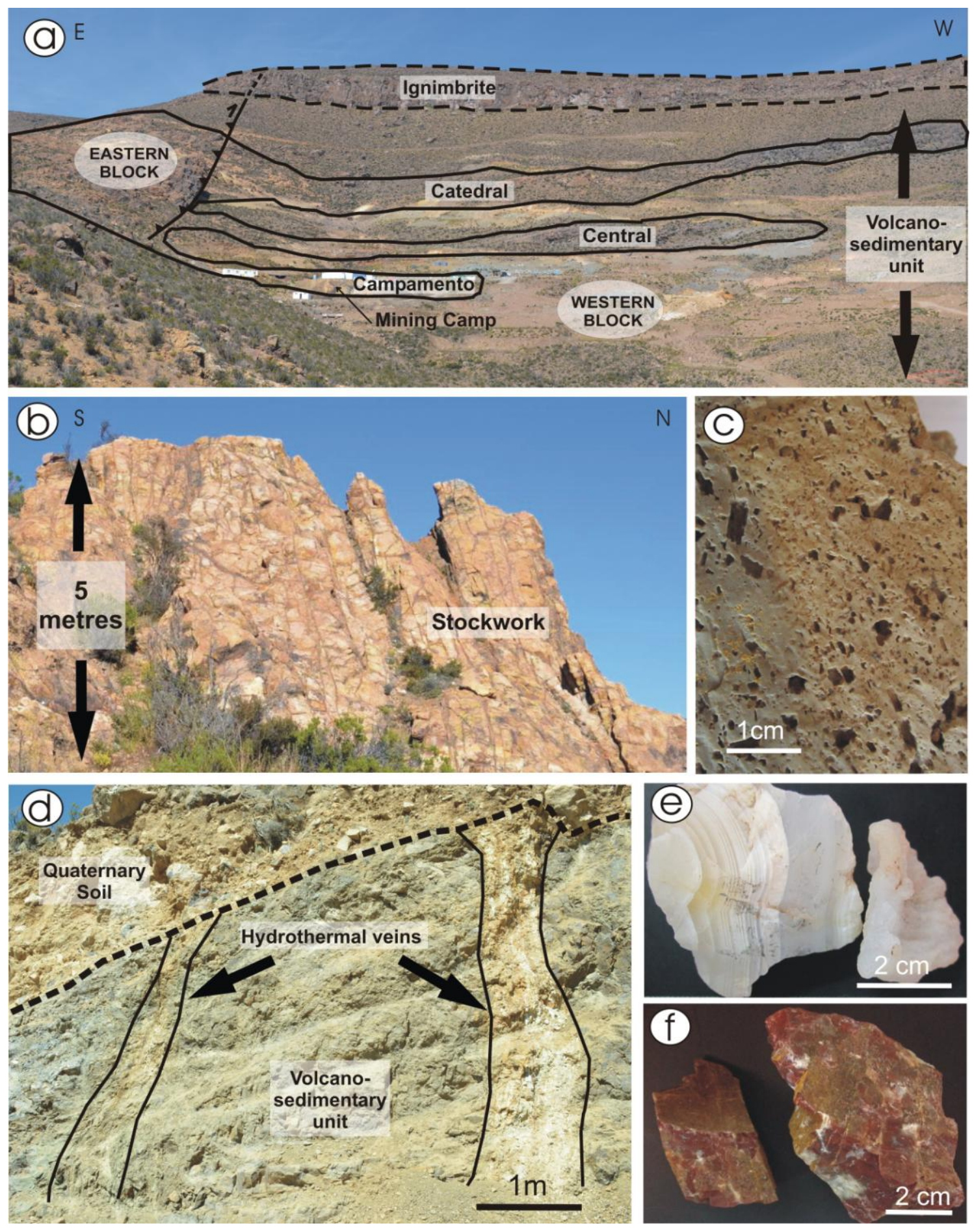

Figure 3 

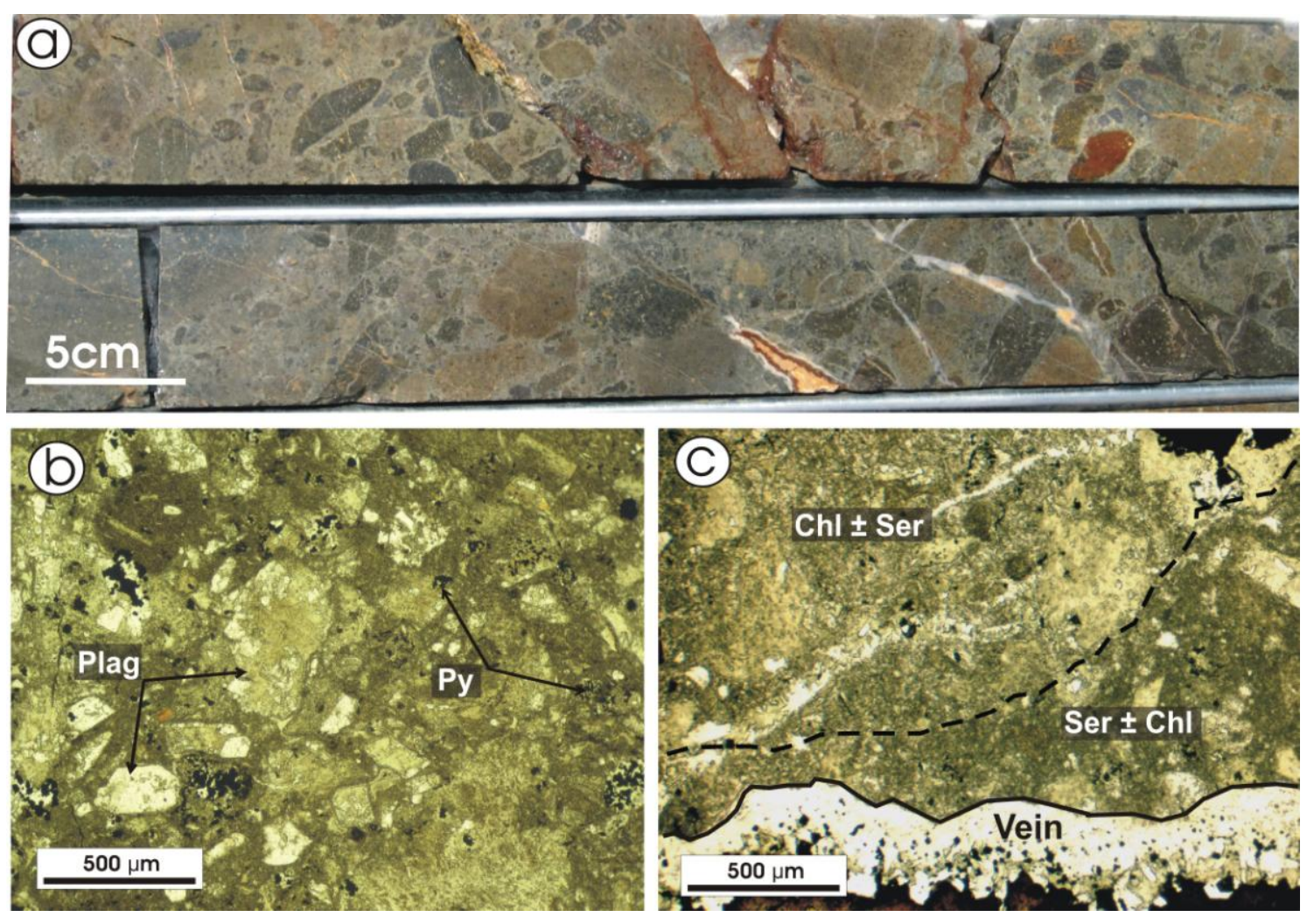

Figure 4 

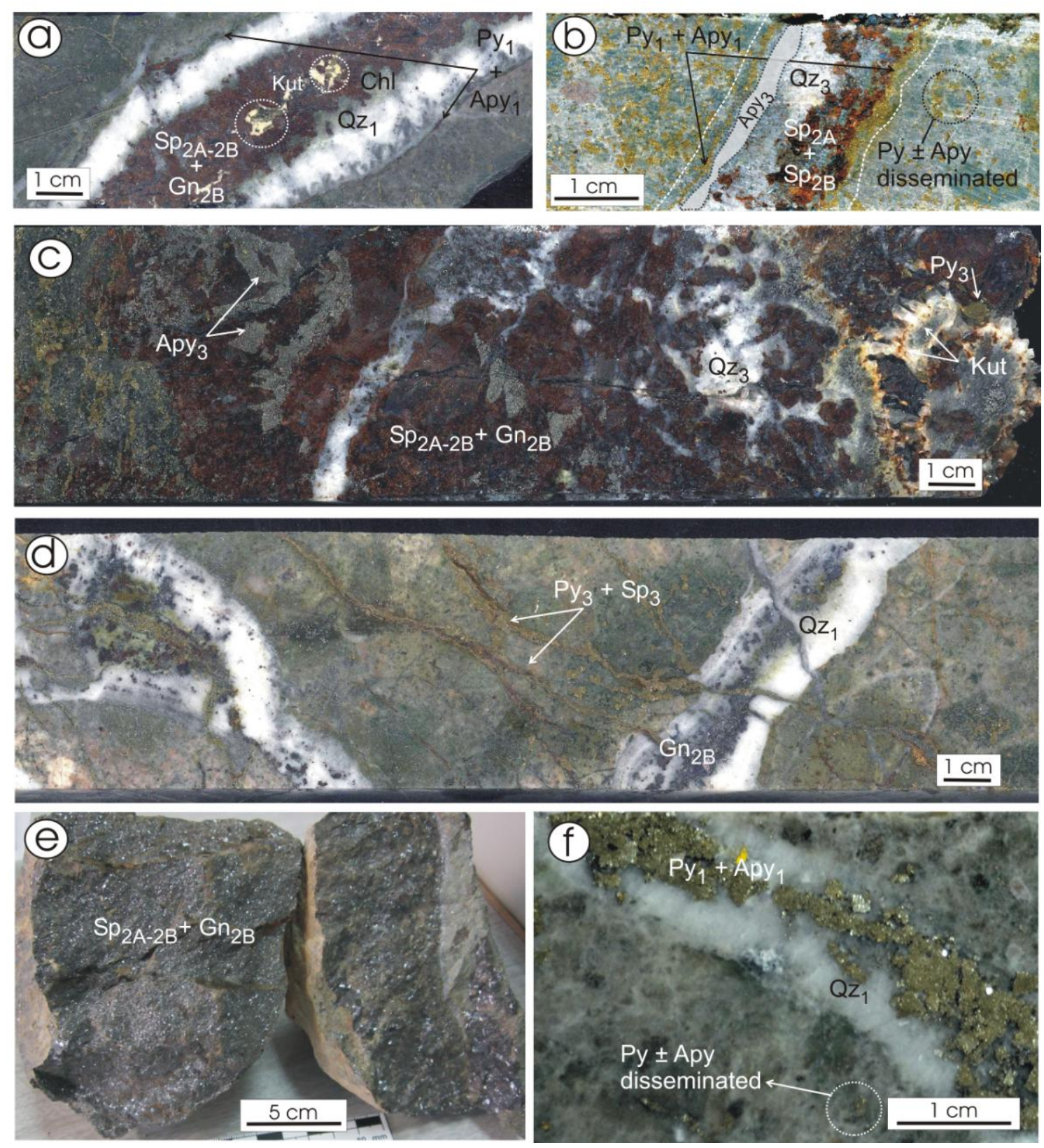

Figure 5 


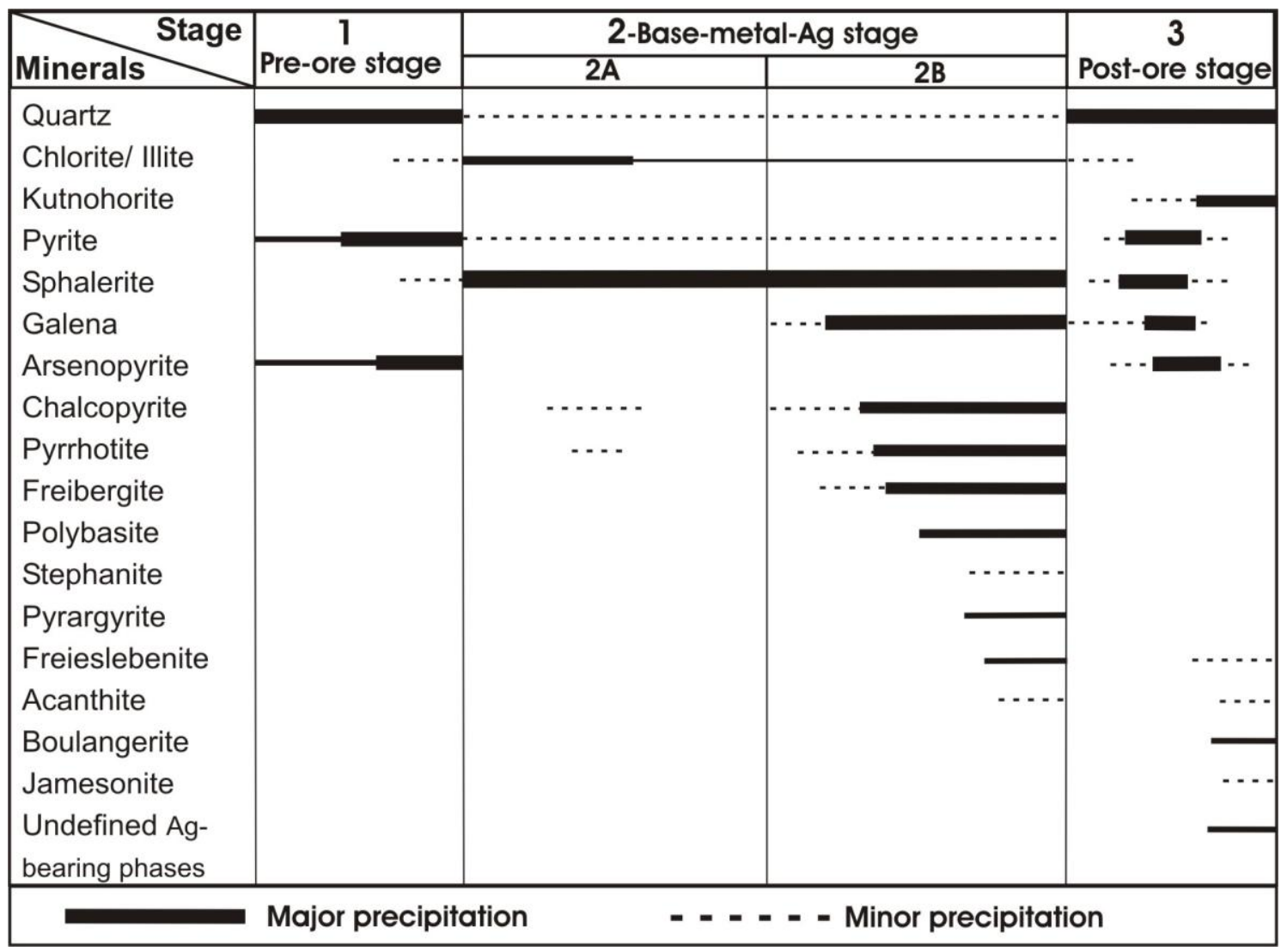

Figure 6 


\section{PRE-ORE STAGE}
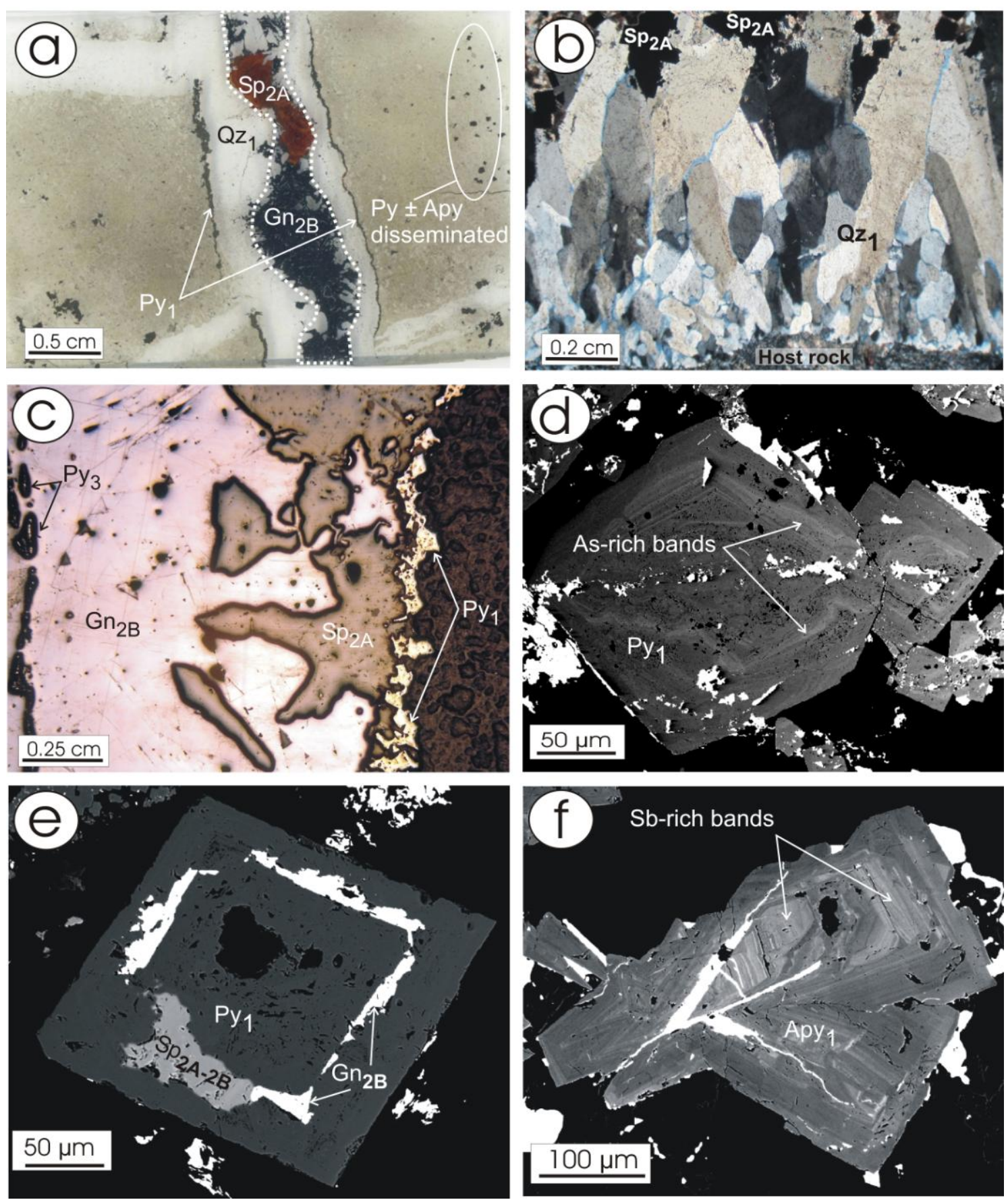

Figure 7 
BASE METAL (MAIN ORE) STAGE
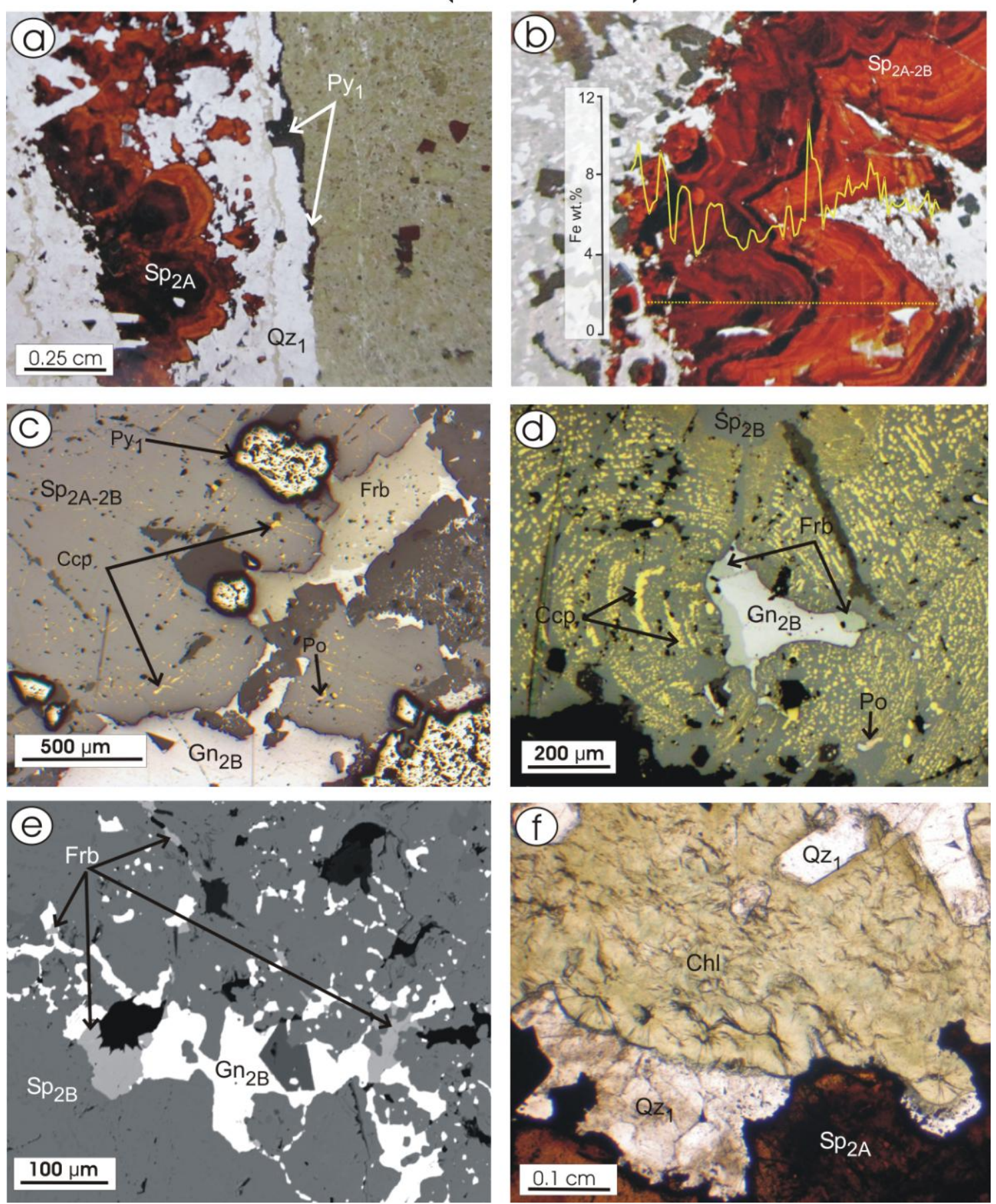

Figure 8 


\section{POST ORE STAGE}
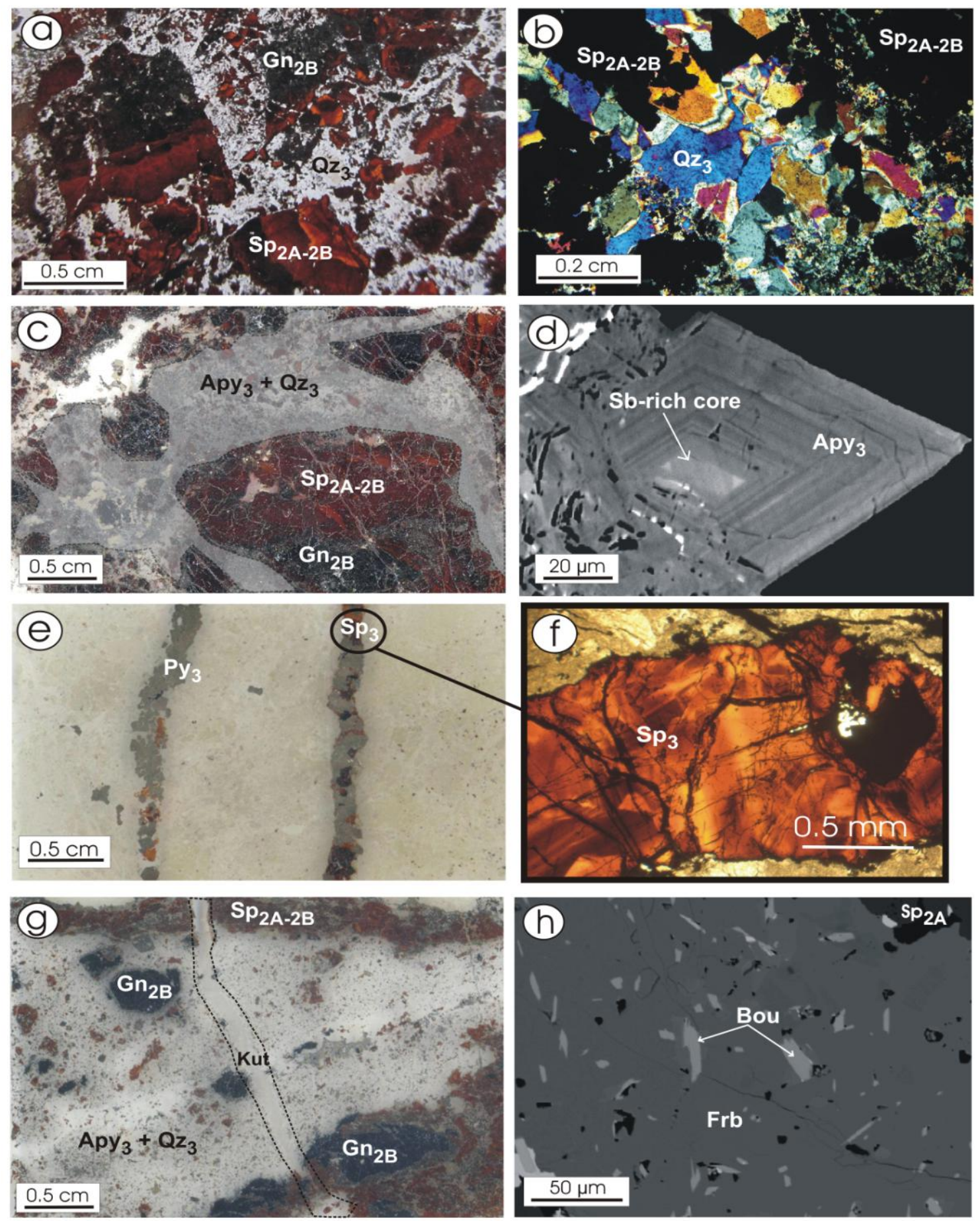

Figure 9 

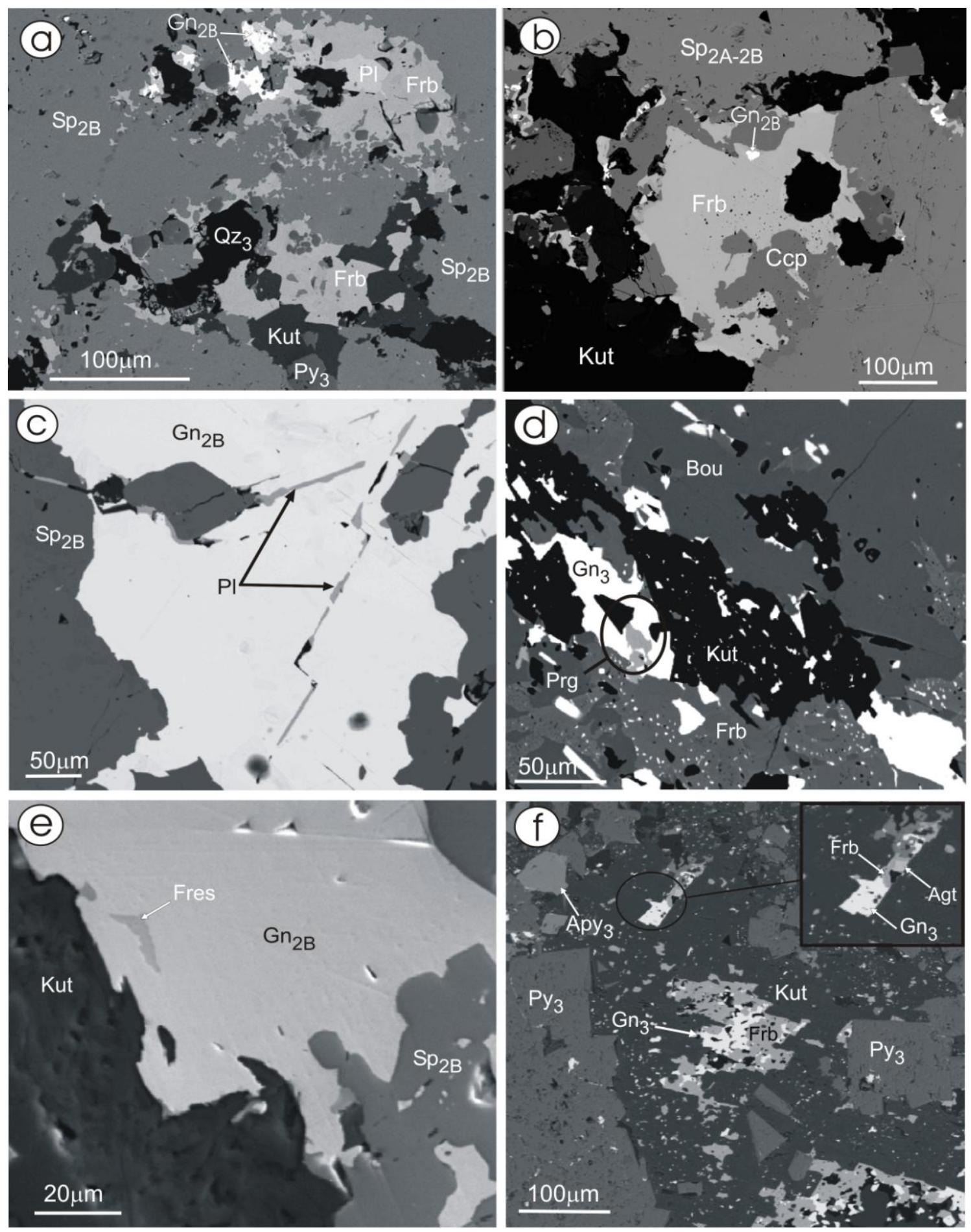

Figure 10 

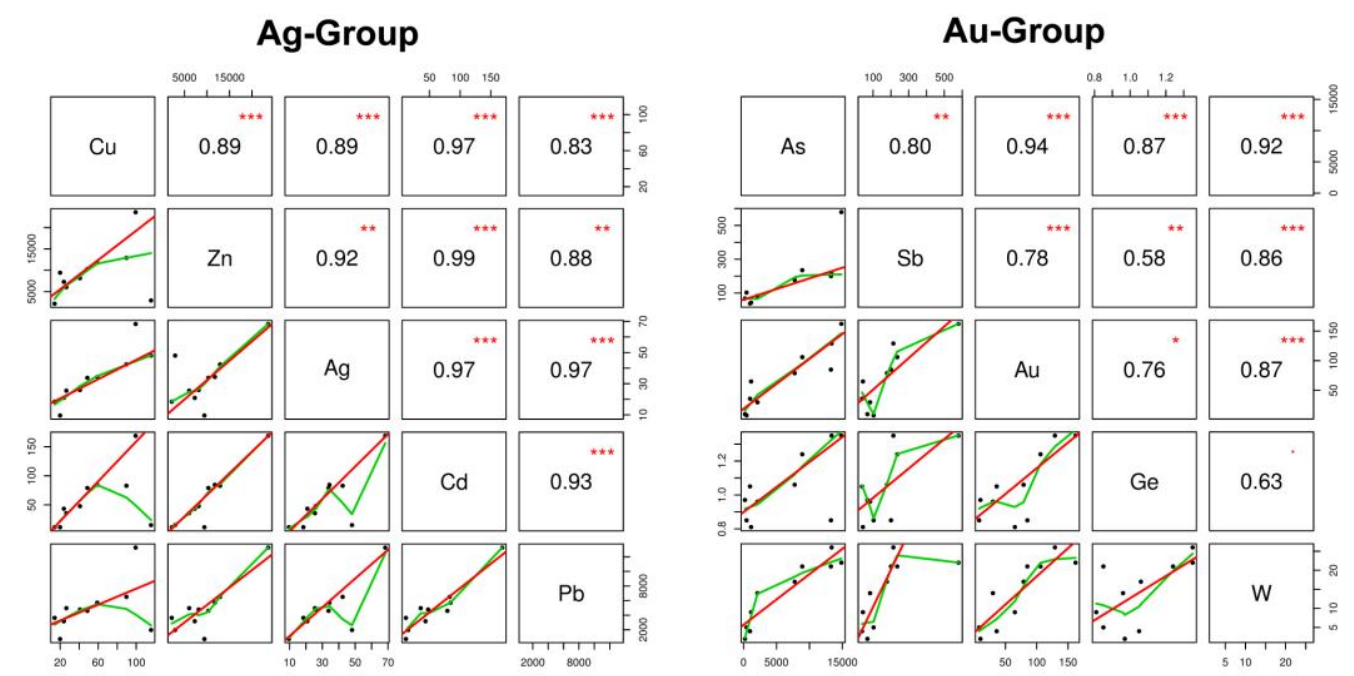

Figure 11 

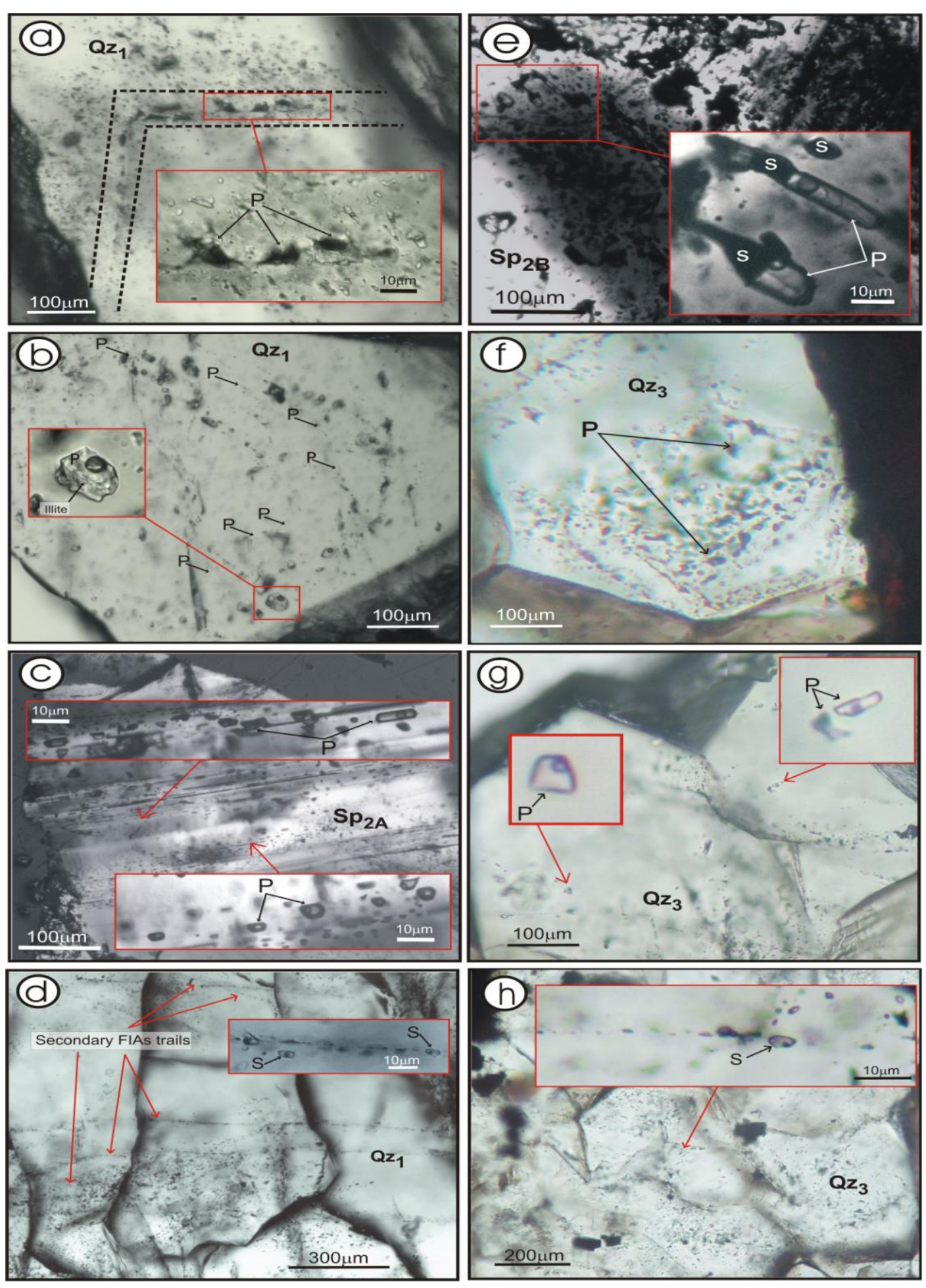

Figure 12 


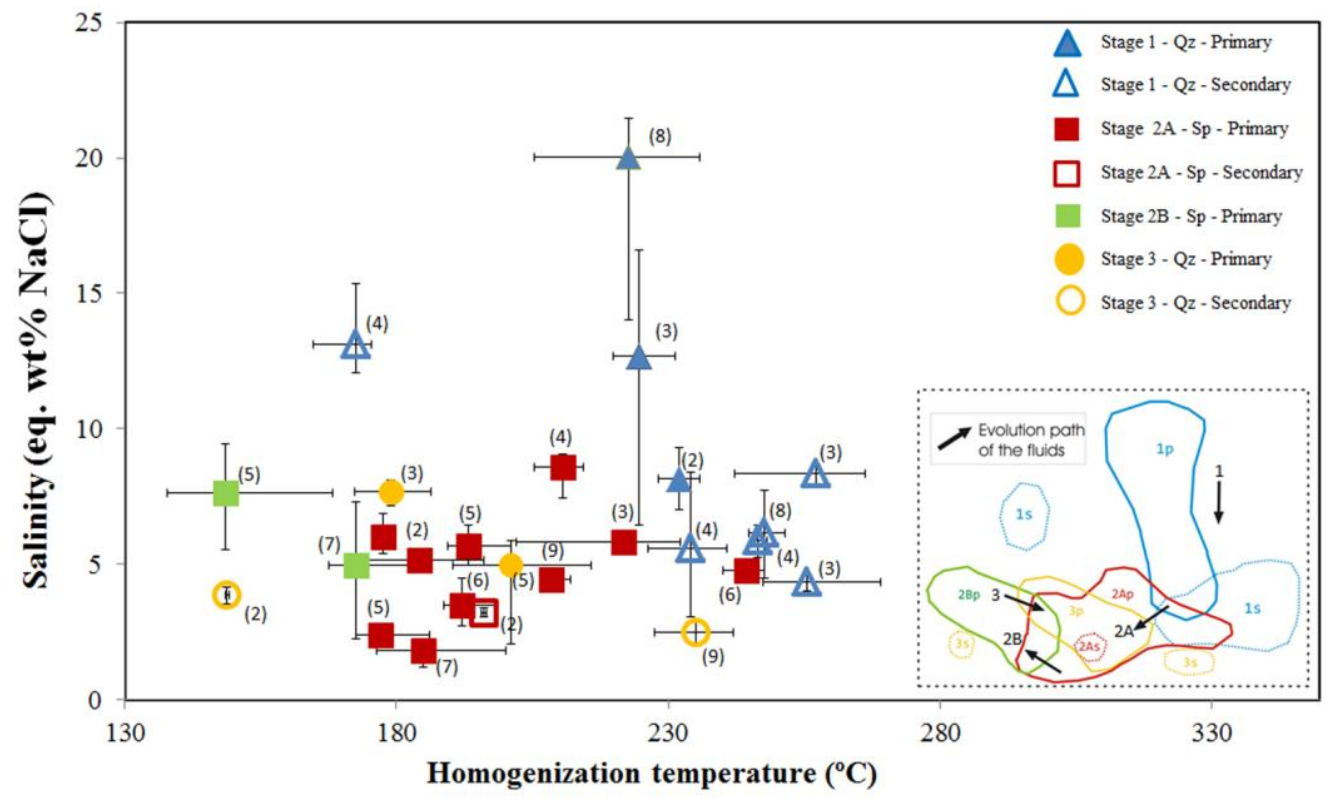

Figure 13 


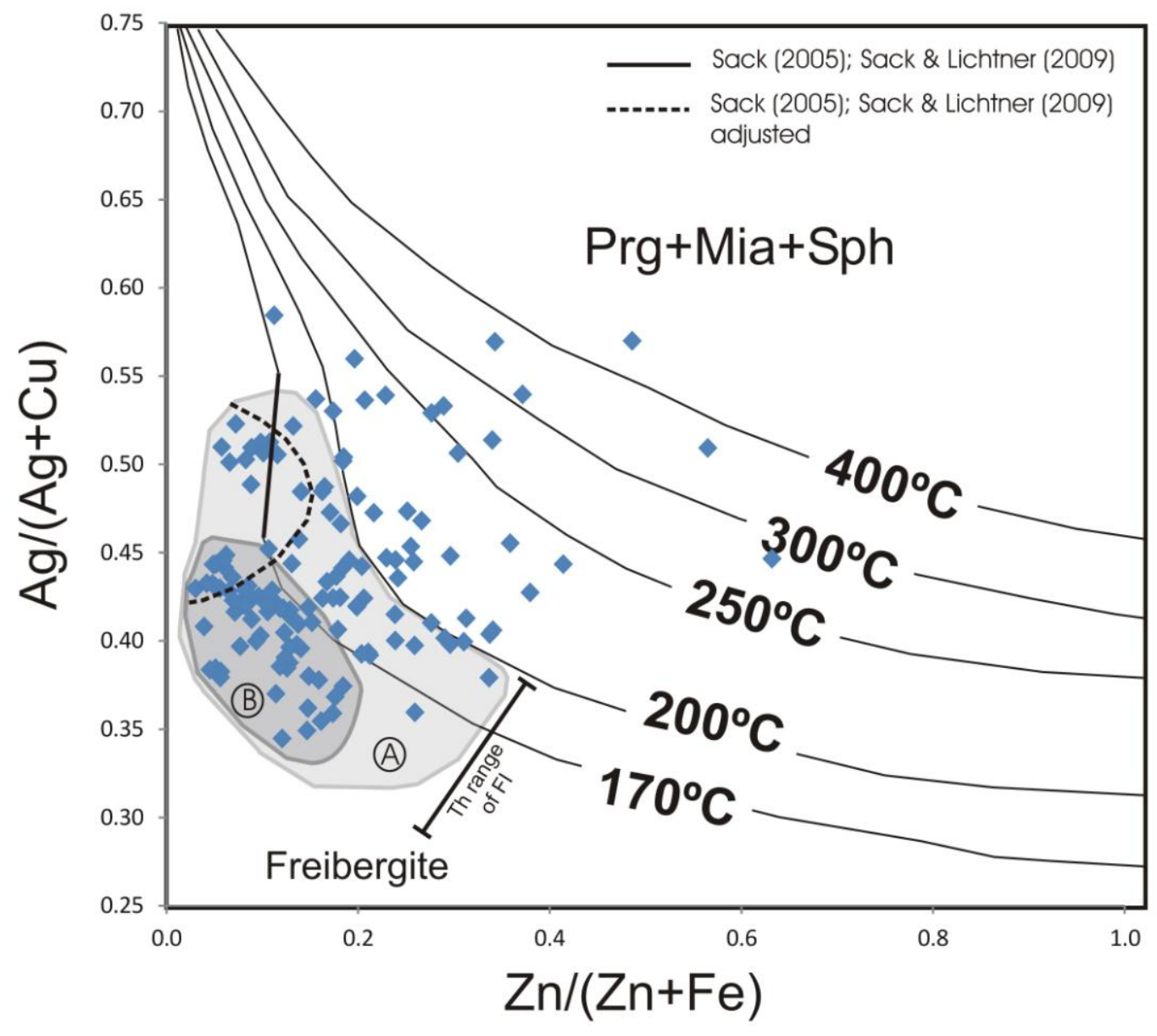

Figure 14 


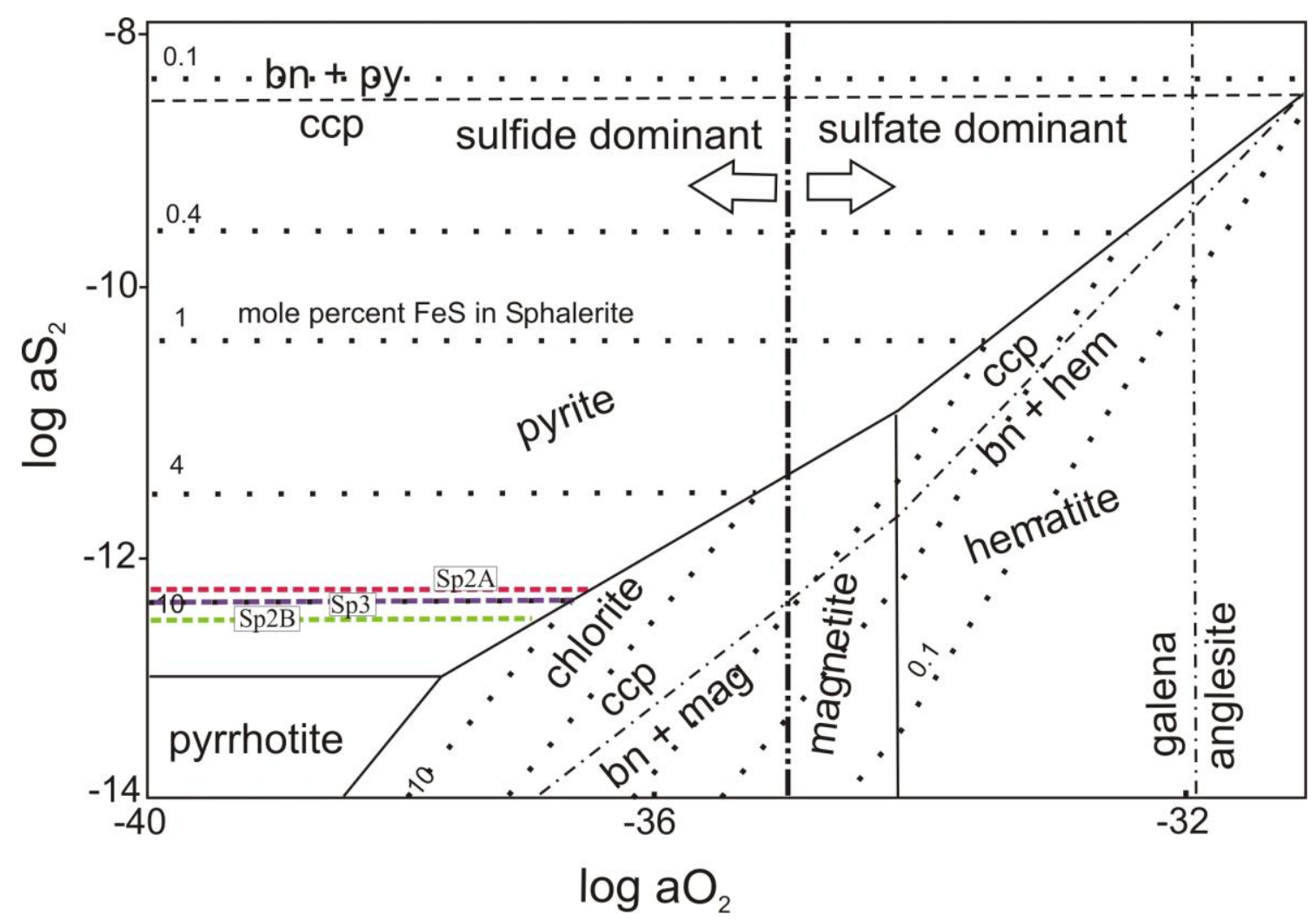

Figure 15 


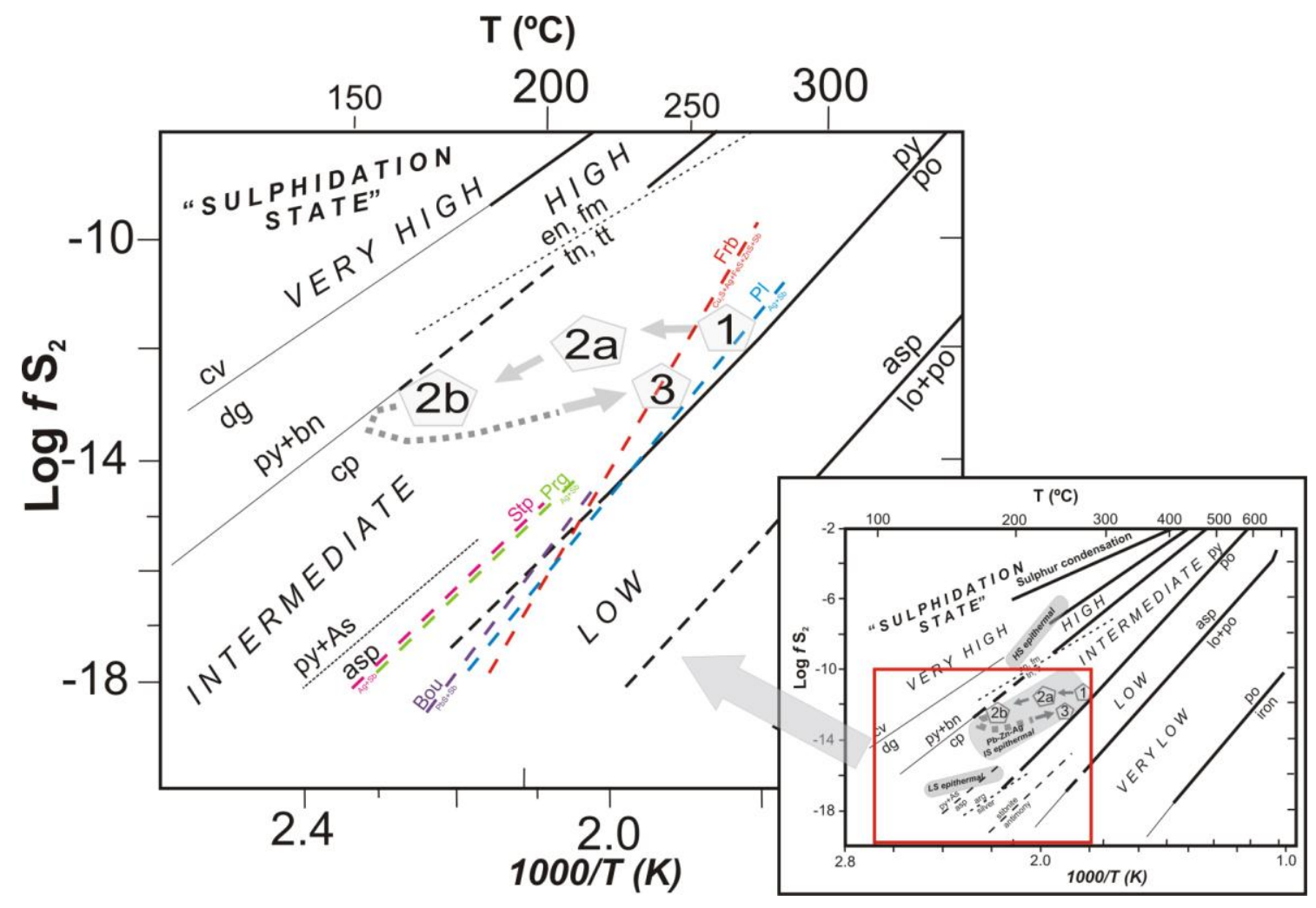

Figure 16 


\section{Figure captions}

Fig. 1. (a) Location of the Patricia deposit and other Cenozoic deposits and prospects within major metallogenic belts of northern Chile and southern Peru (modified from Camus and Dilles 2001) (b) Simplified regional geologic map of the Tarapacá region. The location of the Patricia deposit and nearby deposits and prospects in the area (Cerro Colorado, Sagasca, Yabricoya, Mocha and Queen Elizabeth) are shown.

Fig. 2. (a) Simplified geological map showing the location of the three prospects (Patricia, Doris, La Rosa) within the Paguanta Mining Exploration Project (b) Geological map of the Patricia deposit showing the main units and the location of the three main mineralized veins (Campamento, Central and Catedral). Location of the drillcore sampling is also shown in the map. Drill cores are commonly N-S oriented and $\operatorname{dip} 40-60^{\circ} \mathrm{S}$.

Fig. 3. (a) General view of the western block in the Patricia ore deposit with the mineralized units within the volcano-sedimentary unit represented in solid lines and the post-mineralization unit represented by dashed lines. The main thrust fault system and the position of the western and eastern blocks are also shown, (b) overview of the Patricia silicification and stockwork area in the eastern block, (c) detailed photograph of the vuggy silica texture observed at Patricia ore deposit, (d) general geometry of the hydrothermal vein system in the western block, (e-f) sample of amorphous silica and jasperoids, respectively, located in the Patricia western block.

Fig. 4. (a) Drill core section showing the volcanic and volcano-clastic andesitic breccias hosting the mineralization and regionally affected by chloritic alteration. Photomicrographs in transmitted light with one polarizer of: (b) the typical altered host rock in the Patricia deposit affected by chloritic alteration (greenish to brownish colors). Relicts of plagioclase and disseminate of pyrite are also visible and (c) vein 
showing sericitic (illite) alteration selvage overprinting the chloritic alteration of the host rock. Abbreviations: $P y=$ Pyrite, Plag $=$ Plagioclase, $C h l=$ Chlorite, $\operatorname{Ser}=$ Sericite.

Fig. 5. Drill-core sections showing the different types of mineralized veins observed in the Patricia ore deposit; (a) symmetric, (b) asymmetric, (c) brecciated sulfides cemented by $\mathrm{Qz}_{3}$ and $\mathrm{Apy}_{3}$, (d) veinlets of pyrite and sphalerite, (e) massive sulfide and (f) veinlets mainly composed of quartz and pyrite \pm arsenopyrite. Abbreviations: $P y_{1}=$ Pyrite stage $1, A p y_{1}=$ Arsenopyrite stage $1, S p_{2 A}=$ Sphalerite stage 2A, $S p_{2 B}=$ Sphalerite stage $2 \mathrm{~B}, G n_{2 B}=$ Galena stage $2 \mathrm{~B}, P y_{3}=$ Pyrite stage $3, S p_{3}=$ Sphalerite stage 3 , $G n_{3}=$ Galena stage 3, $A p y_{3}=$ Arsenopyrite stage 3, $Q z_{1}=$ Quartz stage 1, $Q z_{3}=$ Quartz stage 2 and $K u t=$ Kutnohorite.

Fig. 6. Mineral assemblages and paragenetic sequence present in the Patricia ore deposit. Thick bars indicate higher abundances, thin and dashed lines refer to lower abundances.

Fig. 7. Photomicrographs of pre-ore stage samples; (a) detailed photograph of a thin section showing the typical occurrence of $\mathrm{Py}_{1}$ near the vein-wallrock contact. (b) photomicrograph in transmitted light, crossed-polar, showing the typical "comb" texture of quartz $\left(\mathrm{Qz}_{1}\right)$, (c) reflected light photomicrograph, one polar, showing $\mathrm{Py}_{1}$ at the contact between the host rock and the mineralized vein. EPMA photomicrographs; (d) zoned idiomorphic grain of $\mathrm{Py}_{1}$ with As-rich bands, (e) $\mathrm{Py}_{1}$ grain being replaced by galena and sphalerite, (f) zoned idiomorphic grain of $\mathrm{Apy}_{1}$ with Sb-rich bands. Abbreviations: $Q z=$ quartz, $P y=$ pyrite,$A p y=$ arsenopyrite, $G n=$ galena, $S p=$ sphalerite .

Fig. 8. Photographs of samples from de base-metal and silver stage: (a) detailed photograph of a thin section showing zoned sphalerite grains, $\mathrm{Sp}_{2 \mathrm{~A}}$, within a symmetrical vein, (b) Fe concentration map superimposed onto a grain of Fe-zoned sphalerite, $\mathrm{Sp}_{2 \mathrm{~A}} \cdot(\mathrm{c}-\mathrm{d})$ photomicrographs in reflected light, one polar, showing the typical texture of the sphalerite, $\mathrm{Sp}_{2 \mathrm{~B}}$, in relationship to chalcopyrite, galena, pyrrhotite and freibergite, (e) EPMA photomicrographs showing the typical distribution of Ag-bearing mineral 
within galena and filling voids between sphalerite, (f) Photomicrographs in transmitted light, one polar, showing chlorite at the contact with sphalerite. Abbreviations: $S p=$ sphalerite, $P y=$ pyrite, Frb $=$ freibergite, $G n=$ galena, $C c p=$ chalcopyrite, $P o=$ pyrrhotite, $C h l=$ chlorite and $Q z=$ quartz.

Fig. 9. Photographs of post-ore stage samples: (a) detailed photograph of a thin section (DPTS) showing the typical brecciated texture of sulfides cemented by quartz. (b) Photomicrograph with transmitted light, crossed-polar, showing mosaic (jigsaw)-textured quartz as a cement of the brecciated sulfides. (c) DPTS showing the distribution of $\mathrm{Qtz}_{3}$ and $\mathrm{Apy}_{3}$ cementing brecciated sulfides. (d) EPMA photomicrograph of an oscillatory zoned grain of arsenopyrite, $\mathrm{Apy}_{3}$, with a Sb-rich core. (e) DPTS showing thin vein of pyrite, $\mathrm{Py}_{2}$, and sphalerite, $\mathrm{Sp}_{3}$, with the presence of (f) zoned sphalerite crystals. (g) DPTS showing a late-vein of Kut crosscutting $\mathrm{Qz}_{3}$ and the brecciated sulfides. (h) EPMA photomicrograph of a lead sulfosalt (boulangerite) within a silver sulfosalt (freibergite). Abbreviations: $F r b=$ freibergite, Apy = arsenopyrite, $\mathrm{Bou}=$ boulangerite,$G n=$ galena, $K u t=$ kutnohorite, $Q z=$ quartz, $P y=$ pyrite, $S p=$ sphalerite.

Fig. 10. Scanning Electron Microscope photomicrographs: (a) Ag-bearing minerals filling spaces among aggregates of sphalerite grains; EPMA photomicrographs: (b) freibergite filling spaces between sphalerite grains in close association with chalcopyrite, galena and kutnohorite (c) elongated polybasite grains within galena (d) boulangerite, freibergite and pyrargyrite within galena and kutnohorite filling voids in sphalerite (e) freieslebenite within galena (f) tiny acanthite grain and freibergite within galena in a kutnohorite matrix. Abbreviations: Agt = acanthite, Bou $=$ boulangerite, $C c p=$ chalcopyrite, Fres $=$ freieslebenite, $F r b=$ freibergite, $G n=$ galena, $K u t=$ kutnohorite, $P l=$ polybasite, $P y=$ pyrite, $P r g=$ pyrargyrite, $S p=$ sphalerite.

Fig. 11. Matrix of scatterplots of the two groups of elements (Ag and Au groups) with positive correlations calculated from whole-ore composition of the mineralized veins. Lower panels contain the scatterplot of each pair of elements, the model of the robust linear regression (red) and the Tukey 
smoothing line (green). Upper panels contain the $r$ squared coefficient and the level of significance of the robust linear regression $(* * *=0.999 ; * *=0.99 ; *=0.95 ; \cdot=0.90)$. Units are in ppm except for Au which is in ppb.

Fig. 12. Photomicrographs of fluid inclusion assemblages (FIAs) of the three main stages of mineralization: (a-b) Primary FIAs in growth bands of quartz $\left(\mathrm{Qz}_{1}\right)$. (b) Detail of fibrous hydrous phyllosilicate, likely illite, trapped within a primary fluid inclusion. (c) Primary FIAs in $\mathrm{Sp}_{1}$ distributed in parallel growth bands of Sp. (d) Secondary FIAs occurring as parallel trails in $\mathrm{Qz}_{1}$. Note that these inclusions are smaller than primary ones. (e) Primary FIAs in $\mathrm{Sp}_{2 \mathrm{~B}}$ characterized by the presence of chalcopyrite and Ag-sulfosalt inclusions. (f) Dark primary FIAs distributed in parallel growth bands of $\mathrm{Qz}_{3}$. (g) Individual groups of primary FIAs in $\mathrm{Qz}_{3}$. (h) several trails of secondary FIAs in $\mathrm{Qz}_{3}$.

Fig. 13. Range in measured homogenization temperature and salinity of individual fluid inclusion assemblages (FIAs) observed in the Patricia ore deposit. Each data point corresponds to the average homogenization temperature and salinity for the fluid inclusion assemblage and the error bars represent the minimum and the maximum values for each FIA. A possible evolution path of the mineralizing fluids in the deposit is shown in the lower right corner (n) Number of fluid inclusions in each FIA.

Fig. 14. Molar $\mathrm{Ag} /(\mathrm{Ag}+\mathrm{Cu})$ and $\mathrm{Zn} /(\mathrm{Zn}+\mathrm{Fe})$ concentration of freibergite from the Patricia ore deposit compared with the maximum solubility of $\mathrm{Ag}$ in freibergite in the system $\mathrm{Ag}_{2} \mathrm{~S}-\mathrm{Cu}_{2} \mathrm{~S}-\mathrm{ZnS}-\mathrm{FeS}-\mathrm{Sb}_{2} \mathrm{~S}_{3}$ at $170,200,250,300$, and $400{ }^{\circ} \mathrm{C}$ [freibergite in equilibrium with pyrargyrite (Prg), sphalerite (Sph), and miargyrite (Mia)] modified from Sack (2005). It is also shown, with a solid line, the approximate miscibility gap for fahlores for the $170^{\circ} \mathrm{C}$ isotherm calculated by Sack (2005) and, with a dashed black curve, the approximation for the polythermal miscibility gap intersection with the isotherms and translated it downwards in $\mathrm{Ag} /(\mathrm{Ag}+\mathrm{Cu})$ ratios while maintaining the width of the gap calculated at $170^{\circ} \mathrm{C}$ (adjusted from Sack 2005; Sack and Lichtner 2009). 
curve).

Two shaded areas (A-B) delimit the areas with the most common freibergite analysis which indicates temperatures $<200{ }^{\circ} \mathrm{C}$. The darker shaded area (B) below the $170{ }^{\circ} \mathrm{C}$ isotherm shows higher concentration of freibergite. The solid bar show the range of homogenization temperature (Th) of FI observed in sphalerite containing Ag-bearing minerals from sub-stage 2B.

Fig. 15. Activity of sulfur versus activity of oxygen diagram showing the stability fields for the main minerals in the Patricia deposit at $250^{\circ} \mathrm{C}$. Dashed colored lines show the 3 sphalerite assemblages observed in the Patricia ore deposit. Also, show by the heavy vertical dashed-dot line is the boundary between fields of dominant aqueous sulfur species, $\mathrm{H}_{2} \mathrm{~S}$ and $\mathrm{NaSO}_{4}$ at a $\mathrm{pH}=5.4$. Modified from Barton et al., 1977.

Fig. 16. $\log f S_{2}$ vs. Temperature diagram showing the inferred evolution path of the hydrothermal fluids in the Patricia ore deposit. (1) Pre-ore stage; (2a-2b) Base-metal and Ag stage and (3) Post-ore stage, based on observed mineral assemblages, fluid inclusion microthermometry and sulfide geothermometer. The diagram shows the relative sulfidation states of hydrothermal fluids in porphyry deposits and epithermal ore mineral stability fields (modified from Einaudi et al. 2003). 
Table 1 Representative EPMA analyses of the sulfides minerals in the Patricia ore deposit from each stage of mineralization. $\mathrm{n}=$ Number of electron microprobe analyses of each mineral. LOD $=$ limit of detection of the Electron Microprobe for each element in wt.\%. Abbreviations: $P y_{1}=$ Pyrite stage 1, Apy $=$ Arsenopyrite stage $1, S p_{2 A}=$ Sphalerite stage $2 \mathrm{~A}, S p_{2 B}=$ Sphalerite stage $2 \mathrm{~B}, G n_{2 B}=$ Galena stage $2 \mathrm{~B}$, $P y_{3}=$ Pyrite stage 3,S $p_{3}=$ Sphalerite stage 3, Gn $3=$ Galena stage 3,Apy $y_{3}=$ Arsenopyrite stage 3. *b.d= below detection limit.

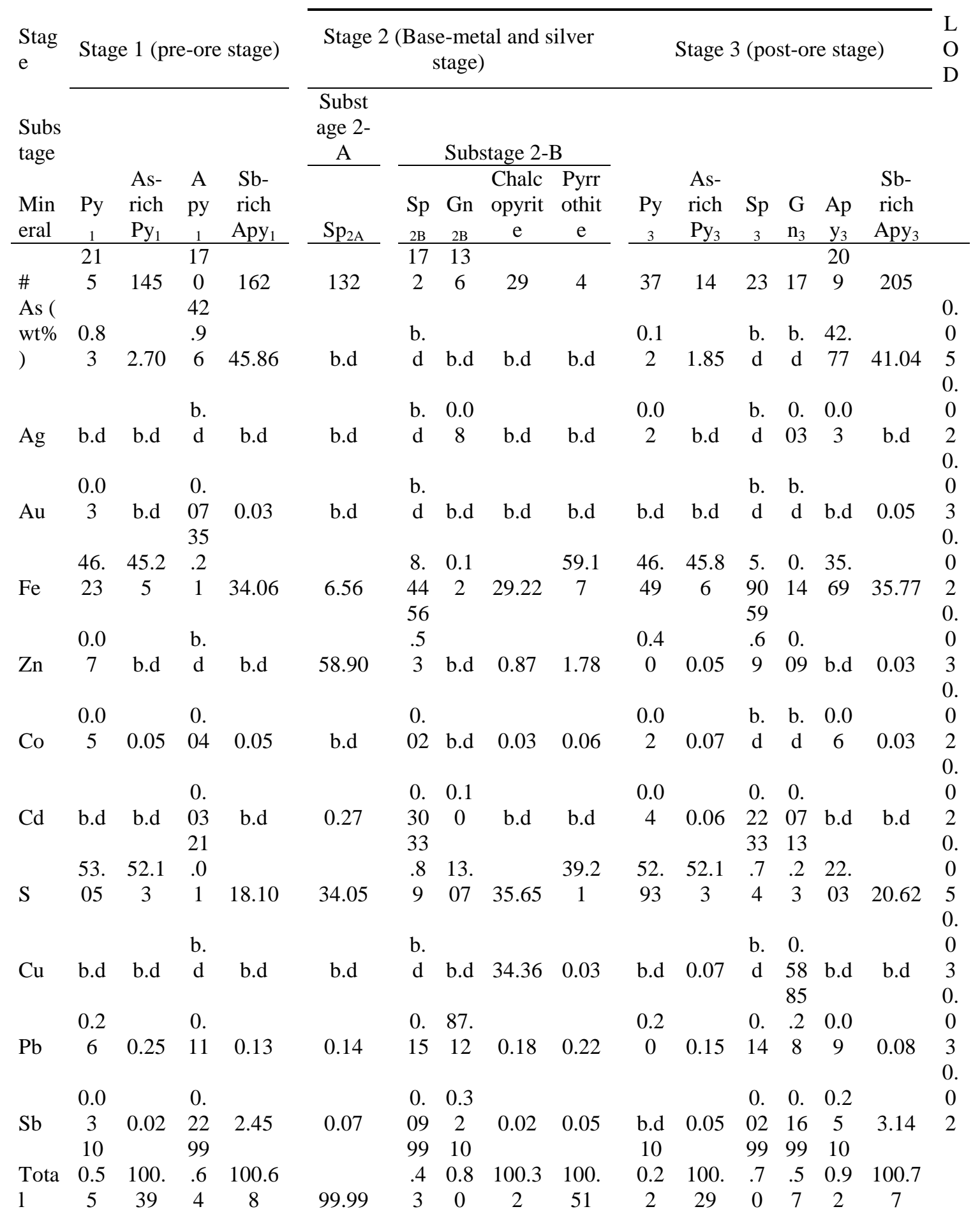


As

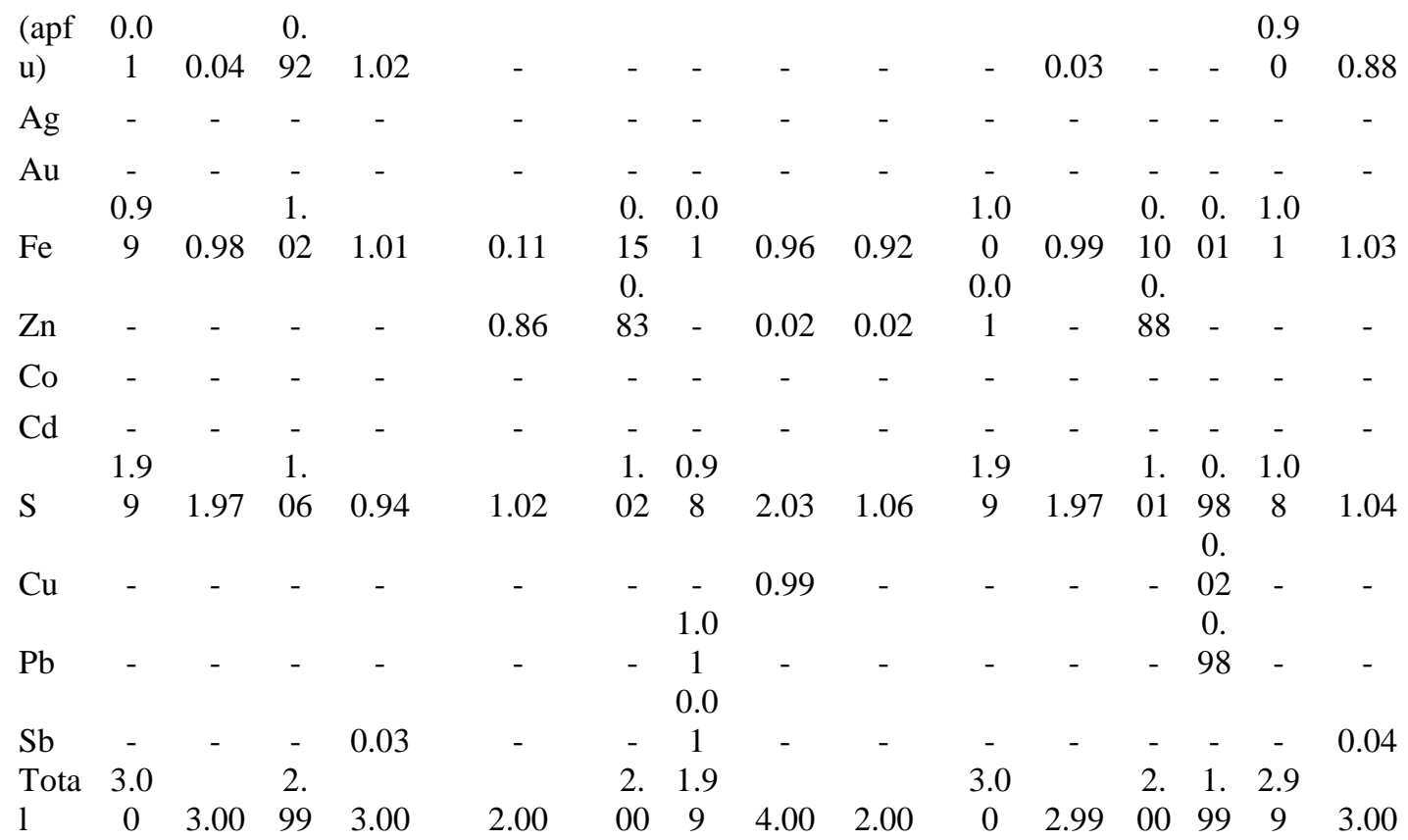


Table 2 Representative EPMA analyses of the Ag-bearing minerals present in the Patricia ore deposit. LOD $=$ limit of detection in wt\%. *b.d = below detection limit. Abbreviations. $P y=$ Pyrite,$S p=$ Sphalerite, $G n=$ Galena, $C c p=$ Chalcopyrite.

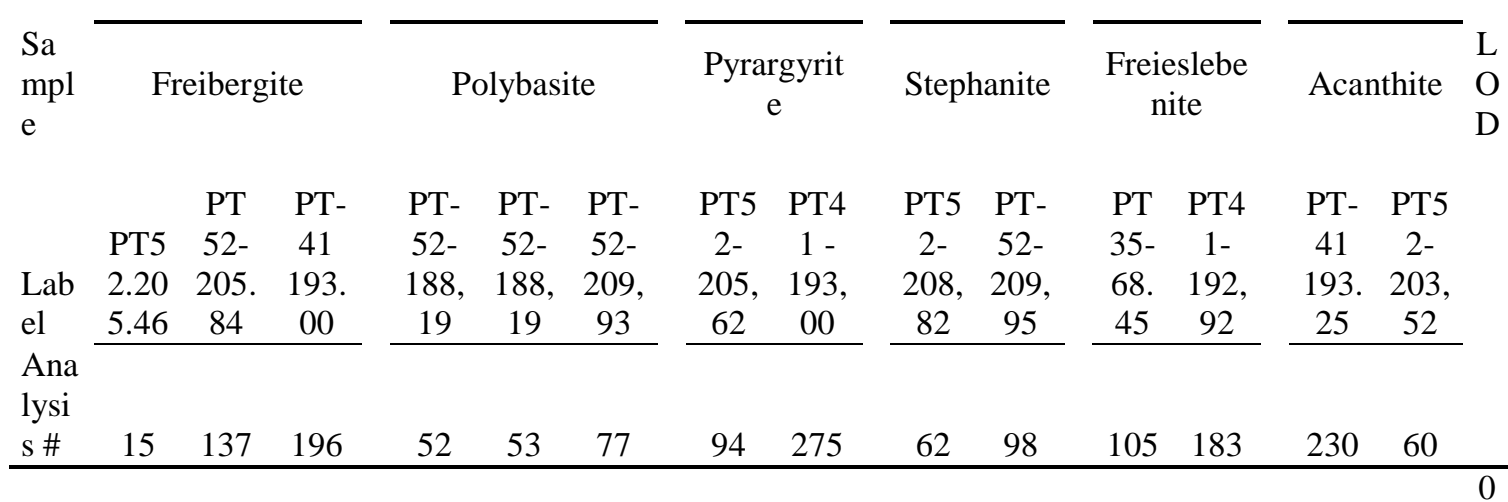

As

(wt

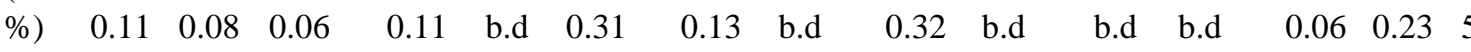

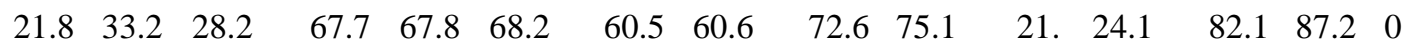

$\begin{array}{llllllllllllllll}\text { Ag } & 6 & 8 & 8 & 8 & 0 & 4 & 2 & 6 & 9 & 9 & 90 & 6 & 6 & 6 & 2\end{array}$

Au b.d b.d b.d b.d b.d b.d b.d b.d $\quad$ b.d $\quad$ b.d $\quad$ b.d $\quad$ b.d $\quad$ b.d $\quad$ b.d 3

0
0

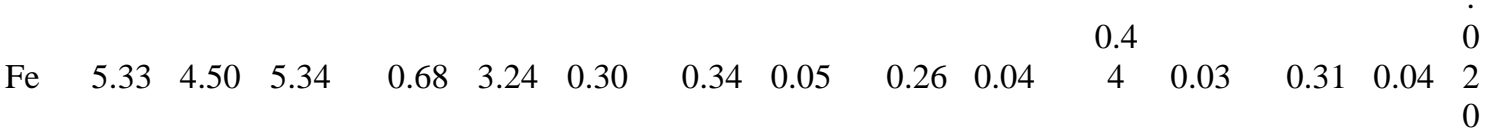

$\begin{array}{llllllllllllllll}\text { Zn } & 1.08 & 1.76 & 0.68 & 0.38 & 0.03 & 0.16 & 0.09 & \text { b.d } & 1.64 & 0.03 & \text { b.d } & 0.10 & 0.08 & 0.03 & 3\end{array}$

Cd b.d $0.27 \quad 0.39 \quad$ b.d b.d b.d b.d b.d b.d b.d b.d $0.34 \quad 1.22 \quad$ b.d $\quad 2$ $\begin{array}{lllllllllllllll}22.0 & 20.3 & 21.0 & 13.9 & 16.2 & 15.3 & 16.8 & 17.0 & 13.7 & 14.4 & 19 . & 18.6 & 15.4 & 10.0 & 0\end{array}$

$\begin{array}{lllllllllllllllll}\mathrm{S} & 1 & 0 & 5 & 3 & 5 & 5 & 4 & 9 & 4 & 8 & 71 & 1 & 7 & 4 & 5 \\ & & & & & & & & & & & & & & \end{array}$

$\begin{array}{lllllllll}22.7 & 13.4 & 15.8 & 0 & 0.04 & 3\end{array}$

$\begin{array}{llllllllllllllll}\mathrm{Cu} & 2 & 9 & 6 & 4.12 & 4.42 & 3.37 & 0.12 & 0.06 & 2.81 & 2.04 & \text { b.d } & \text { b.d } & 0.22 & 0.04 & 3 \\ & & & & & & & & & \end{array}$

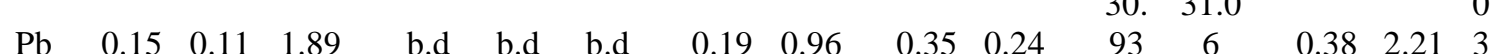




\begin{tabular}{|c|c|c|c|c|c|c|c|c|c|c|c|c|c|c|}
\hline & 27.7 & 25.9 & 27.1 & 13.3 & & 11.3 & 22.5 & 22.8 & & & 27. & 26.5 & & \\
\hline $\mathrm{Sb}$ & 3 & 3 & 8 & 1 & 9.14 & 6 & 4 & 1 & 8.97 & 8.42 & 93 & 5 & 0.10 & b.d \\
\hline Tot & 100. & 99.7 & 100. & 100. & 100. & 99.0 & 100 & 101. & 100. & 100. & 100 & 100. & 100. & 99.8 \\
\hline al & 98 & 3 & 73 & 31 & 92 & 9 & 77 & 66 & 78 & 44 & .92 & 85 & 01 & 5 \\
\hline \multicolumn{15}{|l|}{$\begin{array}{l}\text { As } \\
\text { (apf }\end{array}$} \\
\hline u) & 0.03 & 0.02 & 0.01 & $\begin{array}{l}0.03 \\
14.5\end{array}$ & $\begin{array}{l}0.01 \\
13.6\end{array}$ & $\begin{array}{c}\text { b.d } \\
14.4\end{array}$ & 0.01 & - & 0.03 & - & - & - & - & 0.01 \\
\hline $\mathrm{Ag}$ & 3.70 & 6.05 & 5.03 & 0 & 1 & 5 & 3.06 & 3.05 & 5.37 & 5.57 & $\begin{array}{c}1.0 \\
1\end{array}$ & 1.14 & 1.80 & 2.13 \\
\hline $\mathrm{Au}$ & - & - & - & - & - & - & - & - & - & - & - & - & - & - \\
\hline $\mathrm{Fe}$ & 1.74 & 1.58 & 1.84 & 0.28 & 1.26 & 0.12 & 0.03 & - & 0.04 & 0.01 & $\begin{array}{c}0.0 \\
4\end{array}$ & - & 0.01 & - \\
\hline $\mathrm{Zn}$ & 0.30 & 0.53 & 0.20 & 0.13 & 0.01 & 0.06 & 0.01 & - & 0.20 & - & - & 0.01 & - & - \\
\hline $\mathrm{Cd}$ & - & 0.05 & 0.07 & - & - & - & - & - & - & - & - & 0.02 & 0.03 & - \\
\hline & 12.5 & 12.4 & 12.6 & 10.0 & 10.9 & 10.9 & & & & & 3.0 & & & \\
\hline S & 3 & 2 & 0 & 3 & 8 & 4 & 2.86 & 2.89 & 3.41 & 3.61 & 6 & 2.96 & 1.14 & 0.83 \\
\hline $\mathrm{Cu}$ & 6.53 & 4.16 & 4.79 & 1.50 & 1.51 & 1.21 & 0.01 & 0.01 & 0.35 & 0.26 & - & - & 0.01 & - \\
\hline $\mathrm{Pb}$ & 0.01 & 0.01 & 0.18 & - & - & - & 0.01 & 0.03 & 0.01 & 0.01 & $\begin{array}{c}0.7 \\
4 \\
1.1\end{array}$ & 0.76 & - & 0.03 \\
\hline $\mathrm{Sb}$ & 4.16 & 4.18 & 4.28 & 2.52 & 1.63 & 2.13 & 1.01 & 1.02 & 0.59 & 0.55 & 4 & 1.11 & - & - \\
\hline Tot & 29.0 & 29.0 & 29.0 & 29.0 & 29.0 & 28.9 & & & 10.0 & 10.0 & 6.0 & & & \\
\hline al & 0 & 0 & 0 & 0 & 0 & 1 & 7.00 & 6.99 & 0 & 0 & 0 & 6.00 & 2.99 & 3.00 \\
\hline Size & 250 & & 100 & & & & & & & 145 & & & & \\
\hline$\varnothing$ & $\mu$ & $40 \mu$ & $\mu$ & $90 \mu$ & $20 \mu$ & $45 \mu$ & $15 \mu$ & $20 \mu$ & $65 \mu$ & $\mu$ & $10 \mu$ & $15 \mu$ & $15 \mu$ & $12 \mu$ \\
\hline Hos & & & & & & & & & & & & & & \\
\hline $\mathrm{t}$ & Py / & & & & & & & & & & & & & \\
\hline $\min$ & Gn / & $\mathrm{Sp} /$ & & & $\mathrm{Sp} /$ & $\mathrm{Sp} /$ & & & $\mathrm{Sp} /$ & & & & & \\
\hline eral & Ccp & Gn & $\mathrm{Sp}$ & Gn & Gn & Gn & Gn & Gn & Gn & Gn & Gn & Gn & Gn & Gn \\
\hline
\end{tabular}


Table 3 Bulk rock analyses from mineralized veins in the Patricia ore deposit. *b.d= below detection limit.

\begin{tabular}{|c|c|c|c|c|c|c|c|c|c|c|c|c|}
\hline $\begin{array}{c}\text { Sample } \\
\text { s }\end{array}$ & d.1 & units & 1 & 2 & 3 & 4 & 5 & 6 & 7 & 8 & 9 & 10 \\
\hline $\mathrm{Cu}$ & 0.5 & ppm & $\begin{array}{c}59 \\
1175\end{array}$ & 23.9 & 48.6 & 115.6 & 14.2 & 99.4 & 40.8 & 26.5 & 89.7 & 19.9 \\
\hline $\mathrm{Zn}$ & 1 & ppm & 7 & 7286 & 10304 & 2919 & 2165 & 23597 & 8155 & 6047 & 12903 & 9423 \\
\hline $\mathrm{Ag}$ & 0.01 & ppm & 34.31 & 20.87 & 33.75 & 48.03 & 18.42 & $\begin{array}{c}68.3 \\
168.8\end{array}$ & 25.91 & 25.48 & 42.36 & 9.56 \\
\hline $\mathrm{Cd}$ & $\begin{array}{l}0.02 \\
0.00\end{array}$ & ppm & 84.53 & 43.42 & 79.08 & 15.22 & 11.52 & 7 & 47.76 & 35.65 & 82.92 & $\begin{array}{l}11.5 \\
0.04\end{array}$ \\
\hline In & 5 & ppm & 0.065 & 0.02 & $\begin{array}{l}0.054 \\
2107 .\end{array}$ & 0.065 & $\begin{array}{l}0.056 \\
1142 .\end{array}$ & 0.056 & $\begin{array}{c}0.054 \\
1484\end{array}$ & 0.054 & 0.067 & $\begin{array}{c}4 \\
982 .\end{array}$ \\
\hline As & 0.5 & $\begin{array}{l}\text { ppm } \\
\text { wt. }\end{array}$ & 215.2 & 13257 & 2 & 457.2 & 7 & 7758 & 2 & 13363 & 8911 & 3 \\
\hline $\mathrm{S}$ & 0.01 & $\%$ & 6.16 & $\begin{array}{l}11.66 \\
200.5\end{array}$ & 2.96 & $\begin{array}{c}3.71 \\
102.9\end{array}$ & 7.39 & $\begin{array}{c}8.83 \\
177.7\end{array}$ & 6.18 & $\begin{array}{c}8.66 \\
213.7\end{array}$ & $\begin{array}{c}11.8 \\
235.5\end{array}$ & 1.94 \\
\hline $\mathrm{Sb}$ & 0.05 & ppm & 68.16 & 6 & 82.98 & 9 & 43.06 & 6 & 579 & 7 & 3 & 38.1 \\
\hline $\mathrm{Se}$ & 0.5 & ppm & 0.7 & 6.2 & 2.5 & $\begin{array}{c}\text { b.d } \\
1969 .\end{array}$ & 2.7 & 3.5 & 2.4 & 3.2 & 1.3 & $\begin{array}{r}2.1 \\
732 .\end{array}$ \\
\hline $\mathrm{Pb}$ & 0.5 & ppm & 5717 & 3166 & 4592 & 7 & 3635 & 13265 & 4775 & 4967 & 6512 & 5 \\
\hline $\mathrm{Bi}$ & 0.01 & ppm & 0.13 & 0.86 & 0.42 & 1.03 & 0.08 & 0.3 & 0.17 & 0.33 & 0.41 & 0.84 \\
\hline $\mathrm{Te}$ & 0.05 & ppm & b.d & b.d & b.d & b.d & b.d & 0.59 & b.d & 0.37 & b.d & b.d \\
\hline $\mathrm{Co}$ & 0.1 & ppm & 17.5 & 16.7 & 8.9 & 15 & 12.2 & 22.3 & 8.4 & 14.4 & 8.7 & 27.7 \\
\hline Mo & 0.1 & ppm & 1 & 0.7 & 0.9 & 0.8 & 0.6 & 3.3 & 0.6 & 0.7 & 0.8 & 10.1 \\
\hline $\mathrm{Au}$ & 1 & $\mathrm{ppb}$ & 10 & 85 & 30 & 8 & 65 & 79 & 162 & 129 & 106 & 36 \\
\hline $\mathrm{Ge}$ & 0.05 & ppm & 0.97 & 0.85 & 0.96 & 0.85 & 0.81 & 1.06 & 1.35 & 1.35 & 1.24 & 1.05 \\
\hline W & 1 & ppm & 2 & 21 & 14 & 5 & 9 & 17 & 22 & 26 & 21 & 4 \\
\hline
\end{tabular}


Table 4 Microthermometric results from each fluid inclusion assemblage (FIA) in quartz and sphalerite from each mineralization stage in the Patricia ore deposit.

\begin{tabular}{|c|c|c|c|c|c|c|c|c|c|c|c|c|}
\hline Sample & Vein & $\begin{array}{l}\text { Level } \\
(\mathrm{m})\end{array}$ & $\begin{array}{l}\text { Sta } \\
\text { ge }\end{array}$ & $\begin{array}{c}\text { Host } \\
\text { mineral }\end{array}$ & $\begin{array}{c}\text { Typ } \\
\text { e }\end{array}$ & $\begin{array}{c}\text { FI } \\
\text { A }\end{array}$ & $\begin{array}{l}\mathrm{n} \\
\mathrm{o} .\end{array}$ & $\begin{array}{c}\mathrm{T}_{\mathrm{h}} \\
\text { range } \\
\left({ }^{\circ} \mathrm{C}\right)\end{array}$ & $\begin{array}{c}\mathrm{Av} \\
\mathrm{g}\end{array}$ & 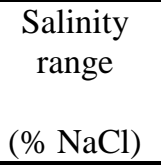 & $\begin{array}{c}\text { Av } \\
g\end{array}$ & $\begin{array}{l}\text { Solid } \\
\text { inclusio } \\
\text { ns }\end{array}$ \\
\hline PT105- & Catedr & & & & & & & $220-$ & 22 & & 12. & \\
\hline 177,60 & al & 145.8 & 1 & Quartz & $\mathrm{P}$ & $1 \mathrm{p} 1$ & 3 & 231 & 5 & $6.4-16.6$ & 7 & - \\
\hline PT109- & Catedr & & & & & & & $228-$ & 23 & & & \\
\hline 235,85 & al & 204.3 & . & . & . & $1 \mathrm{p} 2$ & 2 & 236 & 2 & $7-9.3$ & 8.2 & llite \\
\hline РT96-161 & $\begin{array}{c}\text { Catedr } \\
\text { al }\end{array}$ & 117.7 & . & . & . & $1 \mathrm{p} 3$ & 8 & $\begin{array}{l}205- \\
236\end{array}$ & $\begin{array}{c}22 \\
4\end{array}$ & $14.0-21.5$ & 20 & llite \\
\hline PT96- & Catedr & & & & & & & $248-$ & 25 & & & \\
\hline 158,70 & al & 116.0 & . & . & S & $1 \mathrm{~s} 1$ & 3 & 269 & 6 & $4.0-4.6$ & 4.3 & llite \\
\hline & Catedr & & & & & & & $165-$ & 17 & & 13. & \\
\hline РT96-161 & al & 117.7 & . & . & . & $1 \mathrm{~s} 2$ & 4 & 175 & 2 & $12.0-15.4$ & 1 & - \\
\hline PT109- & Catedr & & & & & & & $245-$ & 24 & & & \\
\hline 235,85 & al & 204.3 & . & . & . & $1 \mathrm{~s} 3$ & 8 & 252 & 8 & $1.7-1.5$ & 6.2 & llite \\
\hline PT73- & Catedr & & & & & & & 205- & 21 & & & \\
\hline 115.95 & al & 93.8 & $2 \mathrm{~A}$ & Sphalerite & $\mathrm{P}$ & $2 \mathrm{p} 1$ & 4 & 214 & 1 & $7.4-9.1$ & 8.6 & - \\
\hline PT73- & Catedr & & & & & & & 173- & 17 & & & \\
\hline 115.95 & al & 93.8 & . & . & . & $2 \mathrm{p} 2$ & 5 & 186 & 7 & $2.1-2.7$ & 2.4 & - \\
\hline PT73- & Catedr & & & & & & & 202- & 22 & & & \\
\hline 115.95 & al & 93.8 & . & . & . & $2 \mathrm{p} 3$ & 3 & 232 & 2 & $5.7-5.9$ & 5.8 & - \\
\hline РT96- & Catedr & & & & & & & 176- & 18 & & & \\
\hline 199,20 & al & 145.7 & . & . & . & $2 \mathrm{p} 4$ & 7 & 200 & 5 & $1.2-2.2$ & 1.8 & - \\
\hline PT96- & Catedr & & & & & & & 190- & 19 & & & \\
\hline 199,20 & al & 145.7 & . & . & . & $2 \mathrm{p} 5$ & 5 & 201 & 3 & $5.0-6.4$ & 5.7 & - \\
\hline PT96- & Catedr & & & & & & & $172-$ & 18 & & & \\
\hline 199,20 & al & 145.7 & . & . & . & $2 \mathrm{p} 6$ & 2 & 196 & 4 & $5.0-5.4$ & 5.2 & - \\
\hline PT105- & Catedr & & & & & & & 177- & 17 & & & \\
\hline $182,80 \mathrm{~B}$ & al & 149.7 & . & . & . & $2 \mathrm{p} 7$ & 3 & 178 & 7 & $5.4-6.9$ & 6 & - \\
\hline PT105- & Catedr & & & & & & & 207- & 20 & & & \\
\hline $182,80 \mathrm{~A}$ & al & 149.8 & . & . & . & $2 \mathrm{p} 8$ & 9 & 212 & 8 & $4.0-4.6$ & 4.5 & - \\
\hline РT96- & Catedr & & & & & & & 240- & 24 & & & \\
\hline 199,20 & al & 145.7 & . & . & . & $2 \mathrm{p} 9$ & 6 & 248 & 4 & $4.3-5.1$ & 4.8 & - \\
\hline PT105- & Catedr & & & & & $2 \mathrm{p} 1$ & & 189- & 19 & & & \\
\hline 183,20 & al & 150.0 & . & . & . & 0 & 6 & 198 & 2 & $2.7-4.5$ & 3.5 & - \\
\hline РT96- & Catedr & & & & & & & 196- & 19 & & & \\
\hline 199,20 & al & 145.7 & . & . & S & $2 \mathrm{~s} 1$ & 2 & 197 & 6 & $3.1-3.4$ & 3.2 & - \\
\hline PT73- & & & & & & $2 b p$ & & $168-$ & 17 & & & \\
\hline 241,40 & Carlos & 195.3 & $2 \mathrm{~B}$ & . & $\mathrm{P}$ & 1 & 7 & 182 & 3 & $2.2-7.3$ & 5 & - \\
\hline PT109- & Catedr & & & & & $2 b p$ & & 134- & 14 & & & \\
\hline 263,40 & al & 228.1 & . & . & . & 2 & 5 & 168 & 9 & $5.6-9.5$ & 7.6 & - \\
\hline РТ96 - & Catedr & & & & & & & $172-$ & 17 & & & \\
\hline 199,20 & al & 145.7 & 3 & Quartz & $\mathrm{P}$ & $3 \mathrm{p} 1$ & 3 & 186 & 9 & $7.2-8.1$ & 7.7 & - \\
\hline РТ96 - & Catedr & & & & & & & $190-$ & 20 & & & \\
\hline 199,20 & al & 145.7 & . & . & . & $3 \mathrm{p} 2$ & 5 & 216 & 1 & $2.1-5.9$ & 5 & - \\
\hline PT73- & Catedr & & & & & & & $227-$ & 23 & & & \\
\hline 115,90 & al & 93.8 & . & . & $\mathrm{S}$ & $3 \mathrm{~s} 1$ & 9 & 242 & 5 & $2.1-2.9$ & 2.5 & Ilite \\
\hline РТ96 - & Catedr & & & & & & & $148-$ & 14 & & & \\
\hline 199,20 & al & 145.7 & . & . & . & $3 \mathrm{~s} 2$ & 2 & 149 & 9 & $3.6-4.2$ & 3.9 & Ilite \\
\hline
\end{tabular}


Table 5 Calculated boiling depths for some fluid inclusions in the Patricia ore deposit. Sample depth means core sample depth below present surface. Boiling depth refers to results from the Haas diagram. The depths represent minimum depths because no evidence of boiling was observed.

\begin{tabular}{lcccc} 
& $\begin{array}{c}\text { Salinity } \\
(\text { wt.\% NaCl})\end{array}$ & $\begin{array}{c}\text { Th } \\
{ }^{\circ} \mathrm{C}\end{array}$ & $\begin{array}{c}\text { Sample depth } \\
(\mathrm{m})\end{array}$ & $\begin{array}{c}\text { Boiling depth } \\
(\mathrm{m})\end{array}$ \\
\hline $\mathrm{Q} 1$ & 20.5 & 235.5 & 118 & 250 \\
$\mathrm{Q} 1$ & 15 & 223.2 & 146 & 220 \\
$\mathrm{Q} 1$ & 9.3 & 235.8 & 205 & 320 \\
$\mathrm{Q} 1$ & 7 & 228.3 & 205 & 300 \\
\hline Sp1 & 9.1 & 205.3 & 94 & 145 \\
Sp1 & 7.4 & 214.3 & 94 & 210 \\
Sp1 & 5 & 189.5 & 146 & 120 \\
Sp1 & 5.1 & 240.1 & 146 & 355 \\
Sp1 & 3.2 & 190.2 & 150 & 123 \\
\hline Sp2 & 4.8 & 170.1 & 195 & 71 \\
Sp2 & 5.6 & 137.9 & 228 & 25 \\
Sp2 & 9.2 & 168.2 & 228 & 65 \\
& & & & \\
\hline
\end{tabular}




\section{Conflict of Interest}

There is no conflict of interest in our work. 
Graphical abstract

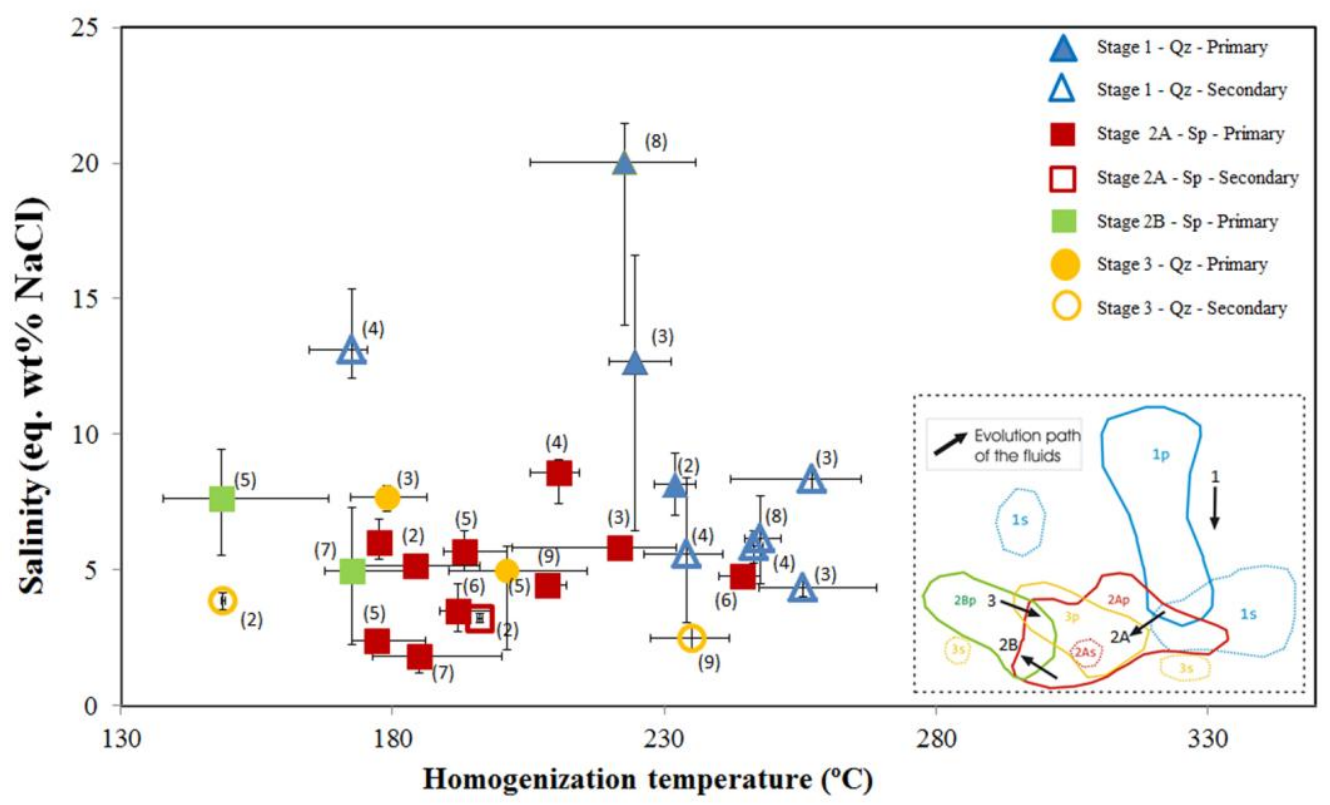




\section{Highlights}

1) Patricia is a recently discovered epithermal deposit located in northeastern Chile

2) Main mineralogy consists of base-metal sulfides, pyrite and Ag-sulfosalts.

3) Mineralization is emplaced as E-W veins within a sinistral strike-slip regime.

4) Mineralogy is consistent with an intermediate sulfidation epithermal deposit type.

5) High potential for hidden economic mineralization at depth in the western block. 